\title{
Arbeidsmarktmonitor Metalektro 2011
}

Citation for published version (APA):

Fouarge, D., de Grip, A., Kriechel, B., van Landeghem, B. G. M., \& van Thor, J. A. F. (2012).

Arbeidsmarktmonitor Metalektro 2011. ROA. ROA Reports No. 001

https://doi.org/10.26481/umarep.2012001

Document status and date:

Published: 01/01/2012

DOI:

10.26481/umarep.2012001

Document Version:

Publisher's PDF, also known as Version of record

\section{Please check the document version of this publication:}

- A submitted manuscript is the version of the article upon submission and before peer-review. There can be important differences between the submitted version and the official published version of record.

People interested in the research are advised to contact the author for the final version of the publication, or visit the DOI to the publisher's website.

- The final author version and the galley proof are versions of the publication after peer review.

- The final published version features the final layout of the paper including the volume, issue and page numbers.

Link to publication

\footnotetext{
General rights rights.

- You may freely distribute the URL identifying the publication in the public portal. please follow below link for the End User Agreement:

www.umlib.nl/taverne-license

Take down policy

If you believe that this document breaches copyright please contact us at:

repository@maastrichtuniversity.nl

providing details and we will investigate your claim.
}

Copyright and moral rights for the publications made accessible in the public portal are retained by the authors and/or other copyright owners and it is a condition of accessing publications that users recognise and abide by the legal requirements associated with these

- Users may download and print one copy of any publication from the public portal for the purpose of private study or research.

- You may not further distribute the material or use it for any profit-making activity or commercial gain

If the publication is distributed under the terms of Article $25 \mathrm{fa}$ of the Dutch Copyright Act, indicated by the "Taverne" license above, 


\section{Arbeidsmarktmonitor Metalektro 2011}

Didier Fouarge

Andries de Grip

Ben Kriechel

Bert van Landeghem

Jesper van Thor

ROA-R-2012/1 


\section{Colofon}

(C) Researchcentrum voor Onderwijs en Arbeidsmarkt (ROA). Niets uit deze uitgave mag op enige manier worden verveelvoudigd zonder voorafgaande schriftelijke toestemming van de directeur van het ROA.

\section{Researchcentrum voor Onderwijs en Arbeidsmarkt}

School of Business and Economics

Maastricht University

\section{Vormgeving}

ROA secretariaat, Maastricht

\section{Verkoop}

Researchcentrum voor Onderwijs en Arbeidsmarkt email: secretary-roa-sbe@maastrichtuniversity.nl website: www.roa.nl

ISBN: 978-90-532I-5OI-2 


\section{Inhoud}

Voorwoord $\quad$ v

Management Summary vii

I Dynamiek in de Metalektro I

I.I Ontwikkelingen in de Metalektro 2OII 2

I.2 Werkgelegenheidsontwikkeling 1996-2010 4

I.3 De uitdagingen: vergrijzing in de Metalektro 5

I.4 De uitdagingen: opleiden 6

I.5 De uitdagingen: innovaties 8

2 Arbeidsmarktontwikkelingen in 201 II

2.I Instroom van personeel in 2OII $\quad$ I2

2.2 Uitstroom van personeel in 2OII I3

2.3 Werkgelegenheidsontwikkelingen in 20II 15

2.4 Opbouw personeelsbestand in de Metalektro I8

3 Vacatures en werving van personeel 2I

3.I Vacatures $\quad 22$

3.2 Effectieve wervingskanalen $\quad 27$

3.3 Wervingsproblemen en bijbehorende maatregelen 32

4 Competenties en opleidingsinspanningen $\quad 4 \mathrm{I}$

4.I Huidig en gewenst competentieniveau 42

4.2 Scholing en competentieontwikkeling 43

4.3 Interne mobiliteit en competentieontwikkeling 50

4.4 HRM-instrumenten gericht op het loopbaanmanagement $5 \mathrm{I}$

$5 \quad$ Innovatie in de Metalektro $\quad 55$

5.I Technologische innovaties $\quad 56$

5.2 Organisatie en management 57

5.3 Inzetbaarheid van het personeel 60

5.4 Outsourcing 62

5.5 Het verband tussen sociale en technologische innovatie 63 
6 Duurzame inzetbaarheid $\quad 67$

6.I Uitstroom vanwege pensionering 68

6.2 Vervangingsproblemen 69

$\begin{array}{ll}6.3 & \text { Aanpak vervangingsproblemen } \\ 6.40\end{array}$

$\begin{array}{ll}6.4 & \text { Leeftijdsbewust personeelsbeleid }\end{array}$

7 Prognoses voor de Metalektro $\quad 75$

7.I Prognose arbeidsmarkt tot 20I6 76

$\begin{array}{ll}7.2 & \text { Verwachtingen bedrijven 20I2-20I3 } \\ 7.3 & 79\end{array}$

7.3 Veranderingen personeel 80

7.4 Speerpunten personeelsbeleid 20I2-20I6 8I

8 Agenda voor de Toekomst: Human capital strategie $\quad 87$ 8.I Human capital: "koop-" en "maakstrategieën” 88

8.2 Agenda voor de Toekomst 90 


\section{Voorwoord}

Met genoegen bieden het Researchcentrum voor Onderwijs en Arbeidsmarkt (ROA) en opdrachtgever Stichting $\mathrm{A}+\mathrm{O}$ u de tiende Arbeidsmarktmonitor Metalektro aan. In tegenstelling tot voorgaande edities van deze rapportage, wordt in de titel niet langer het jaartal genoemd waarin het rapport verschijnt. Vanaf nu wordt in de titel telkens verwezen naar het jaar waarop de rapportage betrekking heeft. Vandaar dat de titel van voorliggende rapportage luidt: Arbeidsmarktmonitor Metalektro 20II (voorheen was dit: Arbeidsmarktmonitor Metalektro, editie 20I2).

De monitor bevat analyses van de actuele en toekomstige ontwikkelingen op personeels- en arbeidsmarktgebied in de Nederlandse Metalektro. De uitkomsten van deze analyses kunnen als input dienen bij het ontwikkelen van personeels- en arbeidsmarktbeleid door de individuele metalektrobedrijven, de sociale partners en andere partijen.

De rapportage die voor u ligt vormt het sluitstuk van een onderzoekscyclus waarbij gedurende een heel jaar op verschillende momenten data zijn verzameld. De hoofdmoot van de bevindingen in de Arbeidsmarktmonitor Metalektro is gebaseerd op de uitgebreide internetvragenlijsten die in juli 201 I en januari 2012 door het werkgeverspanel zijn ingevuld. In elke meting zijn vragen beantwoord met betrekking tot de inen uitstroom en vacatures. Een aantal thema's is verdeeld over één van beide vragenlijsten zoals werving en selectie, inzetbaarheid en doorstroom van personeel, sociale en technologische innovatie en scholing en competenties van het technisch personeel.

Naast de reguliere vragenlijst heeft het werkgeverspanel, aangevuld met andere metalektrobedrijven, vier maal de Quickscan ingevuld waarin zij aangaven hoe de werkgelegenheid en de vacatures zich in de voorgaande en de komende twee maanden ontwikkelden. Om dieper te kunnen ingaan op de achtergronden van de bevindingen uit de vragenlijsten en de Quickscans zijn een aantal metalektrobedrijven geïnterviewd en $\mathrm{A}+\mathrm{O}-$ kenniskringen bezocht. Daarnaast is gebruik gemaakt van gegevens afkomstig van het CBS, PME, SCP, FME-CWM en de arbeidsmarktprognoses van het ROA. ${ }^{\text {. }}$

I. ROA (20II), De arbeidsmarkt naar opleiding en beroep tot 20I6. Rapport in het kader van het Project Onderwijs en Arbeidsmarkt, ROA-R-20II/8, Maastricht: ROA. 
De auteurs willen de bedrijven bedanken die de halfjaarlijkse vragenlijsten en/of de Quickscans hebben ingevuld. Een speciaal woord van dank is daarbij gericht aan de bedrijven die bereid waren om deel te nemen aan de verdiepende gesprekken. De regiecommissie, bestaande uit Henry de Groot (Stichting A+O), Willie Berentsen (FMECWM), Astrid Ophof (FNV Bondgenoten) en Peter Niehoff (FNV Bondgenoten), wordt hartelijk bedankt voor hun constructieve feedback en de wijze waarop ze het onderzoek hebben begeleid. Het veldwerk en de statistische analyses voor deze monitor zijn verricht door Sander Dijksman (ROA) en Olga Skriabikova (ROA).

Maastricht, juni 2012

Prof. dr. T. Dohmen

Directeur 


\section{Management Summary}

Voor de Metalektro was $201 \mathrm{I}$ in het algemeen een goed jaar. Ook al sluimerde er onzekerheid over de algemene economische ontwikkelingen in Europa, toch waren de ontwikkelingen in de sector gunstig. Dit geldt zowel voor de ontwikkeling van de omzet als de werkgelegenheid. In de tweede helft van $201 \mathrm{I}$ werd de onzekerheid over de economische ontwikkelingen echter groter. Hierdoor werden de bedrijven weer voorzichtiger in het aantrekken van nieuw personeel.

\section{Arbeidsmarktontwikkeling in 2011}

De arbeidsmarkt in de Metalektro ontwikkelde zich in $201 \mathrm{I}$ in positieve richting. In vergelijking met 20IO, namen meer bedrijven weer uitvoerende technici in dienst. In de tweede helft van het jaar was er echter sprake van een lichte daling van de personeelsinstroom. Bij minder bedrijven stroomde uitvoerend technisch personeel uit. In 20II was er al met al meer instroom van nieuwe medewerkers dan uitstroom. Dat betekent dat de werkgelegenheid in de sector toenam. De werkgelegenheidsgroei verschilde echter per regio.

Het overgrote deel van het personeel in de Metalektro heeft een vaste aanstelling. Het percentage werknemers met een vast dienstverband bleef in de loop van $201 \mathrm{I}$ vrijwel onveranderd. De omvang van de flexibele schil (tijdelijke en flexibele contracten) is het grootst bij de uitvoerende technische functies en het kleinst bij de leidinggevende technische en niet-technische functies. In de uitvoerende technische functies nam de omvang van de flexibele schil in 20 II wel af van $25 \%$ naar $20 \%$. Daarmee is de omvang van de flexibele schil in de Metalektro even groot als in de andere bedrijfstakken binnen de sector industrie en energie, maar kleiner dan in verschillende dienstensectoren.

\section{Werving personeel}

De arbeidsmarkt in de Metalektro trok in $201 \mathrm{I}$ weer aan. Ten opzichte van de eerste helft van 2010 is het percentage bedrijven dat vacatures had in de eerste helft van $20 I$ in vrijwel elke functiecategorie toegenomen. Dit wijst er op dat de arbeidsmarkt begin $201 \mathrm{I}$ iets krapper was dan in 20IO. De enige uitzondering hierop vormen de ondersteunende niet-technische functies. Evenals in voorgaande jaren wordt er vooral gezocht naar medewerkers voor uitvoerende technische functies. Zes op de tien 
bedrijven hebben vacatures voor deze functies. Daarmee wordt in 20II bijna weer het niveau van voor de crisis bereikt.

Voor het aantrekken van nieuwe medewerkers gebruiken metalektrobedrijven verschillende wervingskanalen. Het uitzendbureau is het meest effectieve wervingskanaal voor het aantrekken van uitvoerende en ondersteunende technici, terwijl voor de werving van technisch opgeleide verkopers en leidinggevend technisch personeel beter gebruik gemaakt kan worden van een commercieel werving- en selectiebureau.

Een kwart van de bedrijven ondervindt in $201 \mathrm{I}$ veel problemen bij het aantrekken van technisch personeel. Deze wervingsproblemen hadden vaak betrekking op de uitvoerende technische functies. De problemen die bedrijven ondervinden bij de werving van technisch personeel manifesteren zich op verschillende manieren. Zo blijken sollicitanten vaak niet over de juiste competenties te beschikken. Ook leiden de personeelstekorten tot een hogere werkdruk voor de medewerkers die bij het bedrijf in dienst zijn. De meest genoemde maatregelen die bedrijven nemen om de tekorten aan technici het hoofd te bieden bestaan uit het inschakelen van externe bureaus en het flexibel inzetten van het huidige personeel.

\section{Technologische en sociale innovaties}

Voor bedrijven in de Metalektro is het cruciaal om innovatief te werken. Daarbij gaat het zowel om het ontwikkelen van nieuwe producten en diensten en technische vernieuwingen van het productieproces, als om het vernieuwen van de organisatie van het werk. De technologische ontwikkeling binnen de Metalektro ligt in 20II weer op hetzelfde hoge niveau als in de jaren voor de crisis. Hoewel de investeringen op het gebied van R\&D op peil blijven, verwachten bedrijven de komende jaren een lichte terugloop van het aantal gerealiseerde technologische innovaties.

Sociale innovatie stond daarentegen in $20 \mathrm{II}$ op een wat lager peil dan in 20IO. Hier speelt wellicht mee dat sociale innovatieprocessen vaak over een langere termijn geïmplementeerd worden. Terwijl ook de productiviteitseffecten van dit soort innovaties zich meestal pas over een langere termijn manifesteren. Daardoor is de pas op de plaats in 20II, na een jaar met veel sociale innovaties, goed te begrijpen: de bedrijven zijn nog bezig met het implementeren van de sociale innovaties die in 2010 zijn doorgevoerd. Voor de komende jaren verwachten de metalektrobedrijven wel weer een toename van het aantal sociale innovaties in hun bedrijf.

Hoe belangrijk deze innovaties zijn blijkt uit de relatie tussen sociale en technische innovaties. Uit de analyses van de data van het Werkgeverspanel Metalektro blijkt dat er een sterk verband is tussen de mate waarin bedrijven sociale en technische innovaties doorvoeren. Sociale innovatie leidt tot meer creativiteit in de organisatie en stimuleert daarmee de technologische vernieuwing. Al met al is de kans dat een 
bedrijf technologische innovaties realiseert maar liefst 20 tot 30\%-punt hoger wanneer het bedrijf sociale innovaties doorvoert.

\section{Voortschrijdende upgrading, PROFI-competenties en brede inzetbaarheid}

Technologische en sociale innovatie leidt in veel bedrijven tot een upgrading van de competenties waarover het personeel moet beschikken. Eenvoudigweg, omdat er meer van de medewerkers wordt gevraagd en omdat verwacht wordt dat medewerkers in staat zijn om zich betrekkelijk snel aan te passen aan nieuwe ontwikkelingen. Voor de komende jaren verwachten metalektrobedrijven een voortzetting van de min of meer trendmatige upgrading van het vereiste opleidingsniveau. De verschuiving vindt plaats van $\mathrm{LBO}$ en $\mathrm{MBO}$ niveau $\mathrm{I}-2$ naar $\mathrm{MBO}$ niveau 3-4 en hoger opgeleid personeel. Dit is overigens een ontwikkeling die zich in vrijwel alle sectoren van de Nederlandse economie voordoet.

De groeiende vraag naar allround technici die zelfstandig kunnen werken, vloeit vooral voort uit de sterke concurrentie die de bedrijven op hun afzetmarkt ondervinden. Om een hoge kwaliteit van de producten te kunnen waarborgen en goed in te kunnen spelen op specifieke wensen van klanten, moet het technisch personeel naast de noodzakelijke vaktechnische competenties ook over gedragsmatige competenties beschikken.

Daarbij ligt de nadruk op probleemoplossend vermogen en flexibiliteit. Bovendien is het erg belangrijk dat medewerkers initiatief nemen, goed kunnen samenwerken en waar nodig kennis willen delen, zowel binnen teams als tussen afdelingen. In de Agenda voor de Toekomst spreken we in dit verband van de zogenaamde PROFI-agenda (zie hoofdstuk 8). Het is overigens opvallend dat veel bedrijven zowel behoefte hebben aan technisch specialisten als aan technische allrounders. Dit illustreert de upgrading van de competentie eisen in de Metalektro.

\section{Opleidingsbeleid en interne mobiliteit}

De vereiste upgrading van het personeel en de toenemende vraag naar technici die ook beschikken over de genoemde PROFI-competenties, vergen aanzienlijke investeringen in trainingen en opleidingen voor het personeel. De uitgaven voor scholing en opleiding als percentage van de loonsom lagen in $201 \mathrm{I}$ echter op een lager niveau dan in 20IO. Ook het percentage werknemers dat in 2011 minimaal één training volgde was in $201 \mathrm{I}$ lager dan in 2010 . In $201 \mathrm{I}$ volgde $46 \%$ van de werknemers in vaste dienst één of meer trainingen of cursussen. Bij de medewerkers die deel uitmaken van de flexibele schil lag de trainingsparticipatie aanmerkelijk lager. In 20 II volgde $23 \%$ van de werknemers met een tijdelijk contract en $6 \%$ van de uitzendkrachten één of meer trainingen. De bedrijven geven aan dat ze in hun scholingsbeleid de komende jaren meer nadruk zullen leggen op trainingen die gericht zijn op het verbeteren van 
gedragsmatige competenties, al blijven de meeste trainingen nog gericht op de vakinhoudelijke kennis.

Vanzelfsprekend blijven aanvullende trainingen en cursussen ook voor de werknemers zelf van groot belang. Om duurzaam inzetbaar te blijven moeten werknemers hun competenties up-to-date houden. Een van de instrumenten daarvoor zijn de in de $\mathrm{CAO}$ vastgelegde opleidingsdagen. Deze worden door een deel van de bedrijven reeds ingezet, maar vanwege het grote belang dat hieraan wordt gehecht, zou er op dit punt nog meer activiteit, ook van de werknemers zelf, verwacht mogen worden.

Naast het volgen van cursussen en trainingen is het informeel leren op de werkvloer van zeer groot belang voor het ontwikkelen van de benodigde competenties. Daarom wordt het bevorderen van coachend leiderschap door veel bedrijven gezien als een speerpunt van hun personeelsbeleid voor de komende jaren. Coachend leiderschap versterkt het informeel leren op het werk en is bij uitstek geschikt om de vereiste PROFI-competenties bij het personeel te ontwikkelen. Het informeel leren kan ook zeer goed worden gestimuleerd door het vergroten van de interne mobiliteit. In 20 II was de interne mobiliteit in de Metalektro iets lager dan in 20IO, maar nog duidelijk hoger dan in het crisisjaar 2009. De helft van de bedrijven geeft aan dat er personeel binnen het bedrijf van functie is veranderd. Deze mobiliteit had in 2011 echter duidelijk vaker een verticaal karakter ('promoties') dan in 2010 . Dit betekent dat vooral de mobiliteit tussen functies die op hetzelfde niveau liggen is afgenomen, terwijl dit juist het mechanisme is dat de flexibele en daarmee duurzame inzetbaarheid van medewerkers op peil houdt.

\section{Vervangingsproblematiek en leeftijdsbewust personeelsbeleid}

Voor de metalektrobedrijven vormen de consequenties van de vergrijzing van het personeelsbestand een belangrijke uitdaging. Volgens cijfers van het pensioenfonds PME is de helft van de werknemers in de sector momenteel 45 jaar of ouder. Metalektrobedrijven zullen de uitdaging van de vergrijzing op twee terreinen moeten aangaan. Ten eerste bij het aantrekken van nieuw personeel dat de vrijkomende functies van medewerkers die met pensioen gaan moet invullen. Daarbij zal rekening gehouden moeten worden met de toekomstige tekorten aan technisch opgeleide schoolverlaters. Ten tweede bij het op peil houden van de inzetbaarheid van medewerkers waardoor deze langer optimaal inzetbaar blijven.

Bedrijven verwachten dat de komende jaren vooral veel uitvoerende technici met pensioen zullen gaan. Opvallend is daarbij echter wel de sterk dalende trend in de verwachte pensioenuitstroom voor alle technische functiecategorieën. Dit houdt waarschijnlijk verband met de latere leeftijd waarop medewerkers met pensioen gaan. Metalektrobedrijven geven aan dat zij de komende jaren de grootste problemen verwachten bij hun zoektocht naar nieuwe uitvoerende technici en leidinggevende technici die de medewerkers die met pensioen gaan moeten vervangen. In 20 II stijgt 
in alle technische functiecategorieën het percentage bedrijven dat veel vervangingsproblemen voorziet bij het invullen van de vacatures die de komende jaren zullen ontstaan door de pensionering van technici.

Bedrijven denken er echter verschillend over hoe zij de vervangingsproblemen die ontstaan door de vergrijzing van het technisch personeel willen aanpakken. Wel zijn de meeste bedrijven doordrongen van het belang om hier adequaat op in te spelen. Daarbij denkt men vooral aan het aantrekken van nieuwe medewerkers die reeds goed zijn opgeleid of die zelf worden opgeleid. Daarnaast verdient het op peil houden van de inzetbaarheid van het personeel alle aandacht. Bedrijven spelen hier op in door een leeftijdsbewust HRM-beleid te voeren.

\section{Verwachte arbeidsmarktknelpunten}

Het ROA voorspelt voor de komende 5 jaar oplopende tekorten aan technisch opgeleiden die bij veel technische functies problemen zullen geven om voldoende nieuwe medewerkers aan te kunnen trekken. In deze functies zal de vraag naar nieuwe medewerkers groot zijn. Niet zozeer doordat de werkgelegenheid in deze functies sterk toeneemt, maar veel meer doordat de komende jaren steeds meer medewerkers met pensioen zullen gaan en vervangen moeten worden om het personeelsbestand op peil te kunnen houden. In totaal wordt voor de Nederlandse economie een tekort van meer dan 150.000 technici verwacht. Meer specifieke prognoses van het ROA voor de technische opleidingen laten zien dat de knelpunten in de personeelsvoorziening vooral groot zullen zijn voor de opleidingen elektrotechniek op MBO- en $\mathrm{HBO}$-niveau en werktuigbouwkunde op HBO- en WO-niveau. De toekomstige tekorten aan technisch opgeleiden maken het ook van groot belang dat meer jongeren een technische opleiding kiezen. Naast het verbeteren van het imago van de techniek is het ook belangrijk dat leerlingen dicht bij huis een technische opleiding kunnen volgen.

\section{Speerpunten toekomstig personeelsbeleid}

Ook de komende jaren blijft het bevorderen van de inzetbaarheid van het huidige personeel in de Metalektro het belangrijkste speerpunt voor het personeelsbeleid. Dit geldt voor bijna tweederde van de bedrijven, terwijl dit in 2010 bij minder dan de helft van de bedrijven een speerpunt voor hun personeelsbeleid was. Daarnaast zijn het verminderen van het verzuim, het bevorderen van coachend leiderschap en het voeren van een leeftijdsbewust personeelsbeleid belangrijke speerpunten voor het personeelsbeleid. Hoewel de noodzaak om een leeftijdsbewust personeelsbeleid te ontwikkelen door steeds meer bedrijven onderkend wordt, geeft toch nog maar $20 \%$ van de bedrijven aan dat dit een van de belangrijkste speerpunten van hun personeelsbeleid is. Dit speerpunt verdient duidelijk meer aandacht gezien de dreigende toekomstige tekorten aan technici en de toenemende vergrijzing van het personeelsbestand waarvan bovendien wordt verwacht dat men langer blijft doorwerken dan de medewerkers die de afgelopen jaren met pensioen zijn gegaan. 
Bijna tweederde van de bedrijven verwacht dat ze problemen zullen ondervinden bij het realiseren van hun speerpunten. In 20 Io was dat overigens nog bij $75 \%$ van de bedrijven het geval. De bedrijven die problemen verwachten, voorzien vooral problemen bij de inzetbaarheid van het personeel dat zij momenteel in dienst hebben. Een derde van de bedrijven verwacht dat hun personeel moeilijk om kan gaan met veranderingen, terwijl een kwart van de bedrijven aangeeft dat hun personeel een te laag kennisniveau heeft om de speerpunten zonder problemen te kunnen realiseren.

\section{Agenda voor de Toekomst}

Het rapport wordt afgesloten met een Agenda voor de Toekomst. Deze agenda biedt metalektrobedrijven handreikingen om de komende jaren de effectiviteit van hun human capital beleid te vergroten. Daarbij wordt ingegaan op de belangrijkste pijlers die deze human capital strategie moet hebben om de concurrentiekracht van de sector op zowel de afzetmarkt als de arbeidsmarkt te versterken. Daarbij wordt een onderscheid gemaakt tussen een koopstrategie (waarbij bedrijven het human capital dat ze nodig hebben op de arbeidsmarkt bij andere bedrijven inkopen) en een maakstrategie, waarbij bedrijven het benodigde menselijk kapitaal binnen hun bedrijf zelf ontwikkelen door te investeren in de verdere ontwikkeling van hun personeel.

Bedrijven zullen hun human capital strategie moeten baseren op hun lange-termijn personeelsbehoefte en daarbij de voor het bedrijf optimale combinatie van "koop- en makkstrategieën" moeten formuleren om in hun toekomstige human capital behoefte te kunnen voorzien. De koop- en maakstrategieën hebben verschillende pijlers die elkaar kunnen versterken. Het wervings- en personeelsontwikkelingsbeleid vormen de belangrijkste pijlers, maar in aanvulling op dit HRM-beleid is het belangrijk om de human capital strategie te verbreden tot de organisaties waarmee wordt samengewerkt: onderwijsinstellingen, toeleveranciers, andere bedrijven in de regio, de flexibele schil, e.d. Om adequaat invulling te kunnen geven aan hun human capital strategie zullen bedrijven door middel van sociale innovatie hun HRM-beleid en externe samenwerking kunnen versterken.

In hoofdstuk 8 wordt deze Agenda voor de Toekomst verder uitgewerkt. 


\section{Dynamiek in de Metalektro}

De Metalektro kende in $20 I I$ een positiefjaar. Ook al sluimerde er een bepaalde mate van onzekerheid over de verdere economische ontwikkeling in Europa, toch waren de ontwikkelingen, zeker in de eerste helft van het jaar, gunstig. Dit geldt zowel voor de ontwikkeling van de omzet als voor de werkgelegenheidsontwikkeling. In de tweede helft van $20 I I$ wordt de onzekerheid over de economische ontwikkeling echter groter. Hierdoor worden de bedrijven ook voorzichtiger in het aantrekken van nieuw personeel.

De Metalektro heeft voor de toekomst een aantal belangrijke uitdagingen die in dit rapport aan de orde zullen komen. Een belangrijke uitdaging vormen de consequenties van de vergrijzing van het personeelsbestand. Volgens cijfers van het pensioenfonds PME is de helft van de werknemers in de sector 45 jaar of ouder. Metalektrobedrijven zullen de uitdaging van vergrijzing op twee terreinen moeten aangaan. Ten eerste bij het aantrekken van nieuw personeel dat de vrijkomende functies van medewerkers die met pensioen gaan moet invullen. Daarbij zal ook rekening moeten worden gehouden met de terugloop van het aantal schoolverlaters. Ten tweede bij het vormgeven van een personeelsbeleid waarin de duurzame inzetbaarheid van de medewerkers een belangrijke rol speelt. In een sector als de metalektro, waar de vereiste kennis en vaardigheden voortdurend veranderen, is opleiden zowel voor de bedrijven als de werknemers van groot belang. Duurzame inzetbaarheid vereist dat werknemers hun competenties up-to-date houden. Een van de instrumenten daarvoor vanuit de CAO zijn de opleidingsdagen waarvan medewerkers gebruik kunnen maken. Deze worden door een deel van de bedrijven al ingezet, maar vanwege het grote belang hiervan zou men hier nog meer activiteit, ook van de werknemers zelf wensen. Ten slotte blijft het een uitdaging voor bedrijven om innovatief te blijven, zowel in het ontwikkelen van producten als in de organisatie van het werk. 


\subsection{Ontwikkelingen in de Metalektro 2011}

De Nederlandse Metalektro werd in 201 gekenmerkt door een fase van herstel. Dit herstel was met name terug te zien in de eerste helft van het jaar, in de twee helft van $201 \mathrm{I}$ was er sprake van toenemende onzekerheid over de economische ontwikkeling. Deze algemene conjuncturele ontwikkeling, onder meer veroorzaakt door een toenemende onzekerheid over de ontwikkelingen rond de euro, had zijn weerslag op de ontwikkeling van de omzet van de Metalektro. Figuur I.I schetst de economische ontwikkeling voor de Metalektro aan de hand van de omzetontwikkeling in de jaren 2007 tot 20II. Uit de figuur blijkt duidelijk dat de crisis van 2008 tot een sterke terugval van de omzet leidde die duurde tot eind 2009. Daarna volgde een periode van herstel, die in de eerste helft van 20 II versnelde. Deze versnelling heeft zich echter in de tweede helft van het jaar niet voortgezet. Hoewel de omzetontwikkeling vanaf de zomer van 20 II nog altijd positief is, viel de groei ten opzichte van de eerste helft van het jaar duidelijk terug.

\section{Figuur 1.1}

Omzetontwikkeling Metalektro, 2007-2011

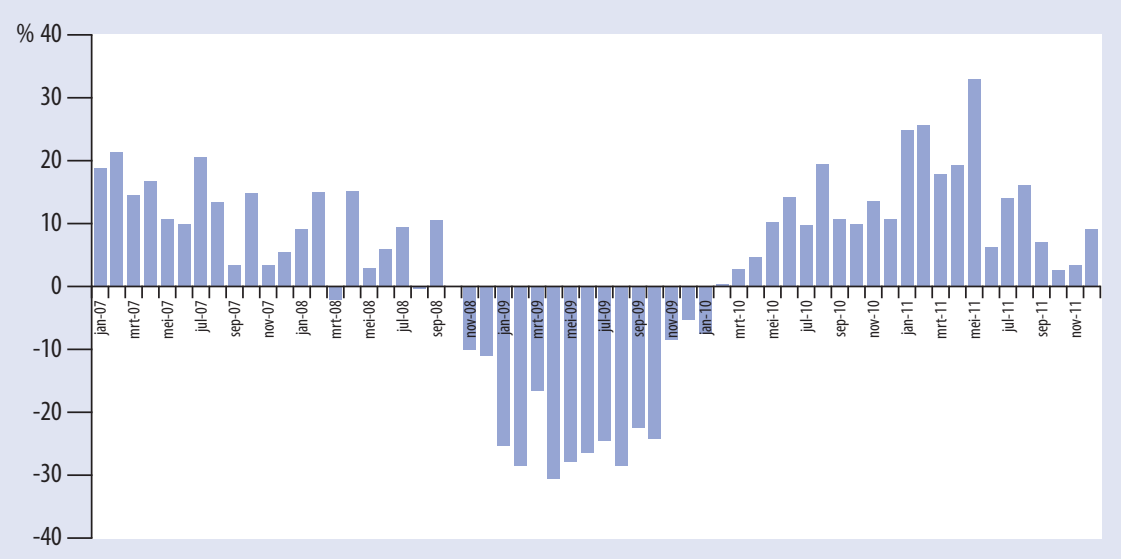

Bron: CBS 2007-2011

De hogere groei van de omzet in de eerste helft van $201 \mathrm{I}$ en de teruglopende groei in de tweede helft van het jaar is ook terug te zien in de werkgelegenheidsontwikkeling binnen de sector. De werkgelegenheid in de Metalektro neemt tot augustus nog verder toe, maar stagneert in de laatste maanden van het jaar. De terugval van de werkgelegenheidsgroei wordt al aangekondigd door de toekomstverwachting van de bedrijven voor de korte termijn. De verwachte werkgelegenheidsontwikkeling valt al duidelijk terug in de juli-meting van de Quickscan. Figuur I.2 schetst deze ontwikkeling aan de hand van de Index Personeelsontwikkeling van de Metalektro, zoals die wordt gemeten op basis van de Quickscan onder de bedrijven. De index geeft de verhouding weer van de groeiende ten opzichte van de krimpende bedrijven. Indien 
deze in evenwicht zijn, staat de index op nul. In dat geval zijn er evenveel bedrijven die aangeven dat zij groeien als dat er bedrijven zijn die krimpen. Op dezelfde wijze wordt ook de werkgelegenheidsverwachting van de bedrijven voor de komende twee maanden gemeten. De figuur laat zien dat de verwachtingen van de bedrijven in het algemeen qua tendens een goede voorspelling zijn voor de ontwikkeling op korte termijn, al was men daarbij vaak iets te pessimistisch over de snelheid van de terugval van de personeelsomvang. Wat dat betreft is het gunstig dat de verwachtingen aan het eind van het jaar op een iets hoger niveau liggen dan de feitelijke werkgelegenheidsontwikkeling. Echter, de algemene tendens blijft de substantiële terugval van zowel de feitelijke personeelsontwikkeling als de werkgelegenheidsverwachtingen in de tweede helft van het jaar.

\section{Figuur 1.2}

Index Personeelsontwikkeling en Werkgelegenheidsverwachting, 2009-2011

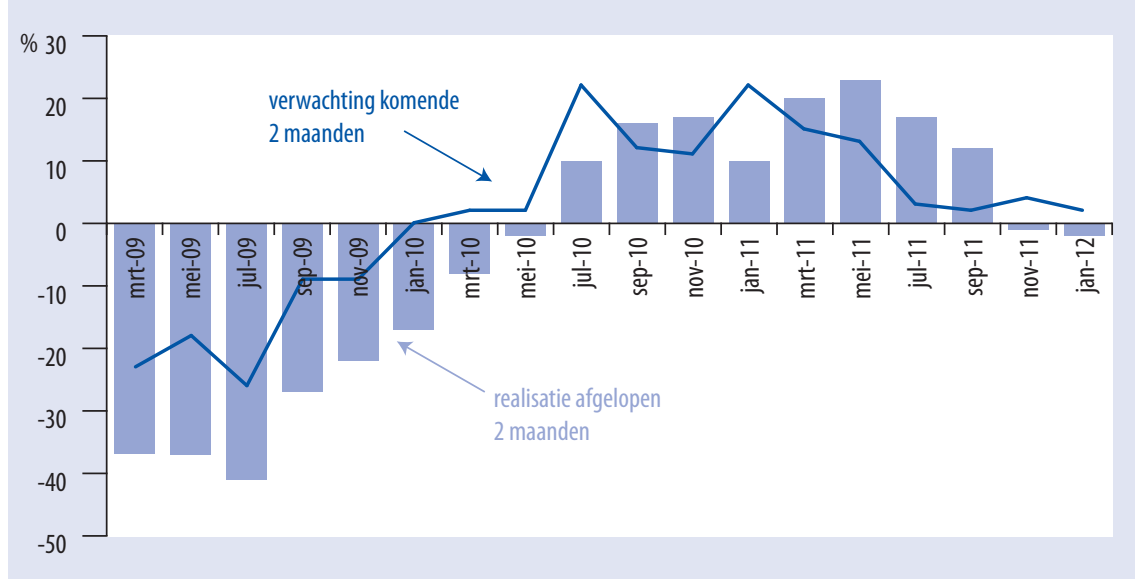

Bron: ROA, Quickscanmonitor Metalektro 2009-2011

Op vergelijkbare wijze als de Index Personeelsontwikkeling en Werkgelegenheidsverwachting, kan ook een index voor de vacatureontwikkeling worden gemaakt (figuur I.3). Deze index geeft de ontwikkeling van het aantal vacatures weer (staven) en de verwachting van de toekomstige ontwikkeling van het aantal vacatures (lijn). In deze index wordt het aantal bedrijven dat een groei van het aantal vacatures verwacht afgezet tegen het aantal bedrijven dat een vermindering van het aantal vacatures verwacht. Een positieve waarde van de index betekent een groei van het aantal vacatures, terwijl een negatieve waarde een krimp van het aantal vacatures weergeeft.

Evenals bij de ontwikkeling van de werkgelegenheidsindex, laat de vacature-index in de eerste helft van het jaar een positieve ontwikkeling zien, terwijl het aantal vacatures tegen het einde van het jaar terugloopt. De figuur laat ook zien dat de vacatureontwikkeling een veel scherper patroon kent dan de ontwikkeling van het personeelsbestand, zoals die in figuur I.2. werd weergegeven. Daarbij blijken de bedrijven in de 
eerste helft van het jaar iets pessimistischer te zijn geweest over de vacatureontwikkeling op de korte termijn dan de feitelijke vacatureontwikkeling. Dit wijst er op dat de verwachtingen van de bedrijven over het vacatureverloop iets later worden gerealiseerd dan men denkt.

\section{Figuur 1.3}

Index Vacatureontwikkeling en -verwachting, 2011

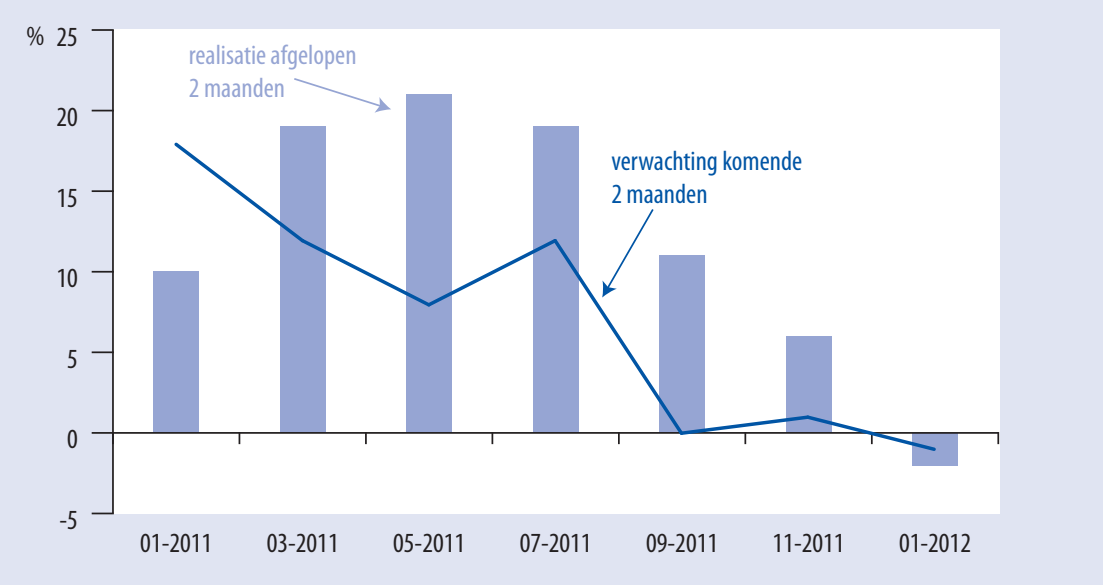

Bron: ROA, Arbeidsmarktmonitor Metalektro, 2011

\subsection{Werkgelegenheidsontwikkeling 1996-2010}

De afgelopen jaren is de werkgelegenheid in de Metalektro structureel gekrompen. Dit is typisch voor de industriële productie in Nederland, waar door de continue stijging van de productiviteit minder personeel nodig is om meer te kunnen produceren. Zo nam de werkgelegenheid in de Metalektro sinds 1996 volgens cijfers van het CBS met bijna 30\% af (figuur I.4). De grootste krimp in de werkgelegenheid was daarbij te vinden in de elektrotechniek, waar de werkgelegenheid over deze periode van Is jaar met bijna de helft gekrompen is. Bij bedrijven in de sector metaalproducten is de werkgelegenheid het minst gekrompen. In deze sector was de daling van de werkgelegenheid in de afgelopen 15 jaar 'slechts' $18 \%$. Overigens is dit binnen de Metalektro wel de sector waar vanwege de recente economische crisis tussen 2008 en 2010 de grootste werkgelegenheidskrimp plaatsvond. 
Figuur 1.4

Ontwikkeling van werkenden in de Metalektro (basisjaar: 2001), 1996-2010 (index)

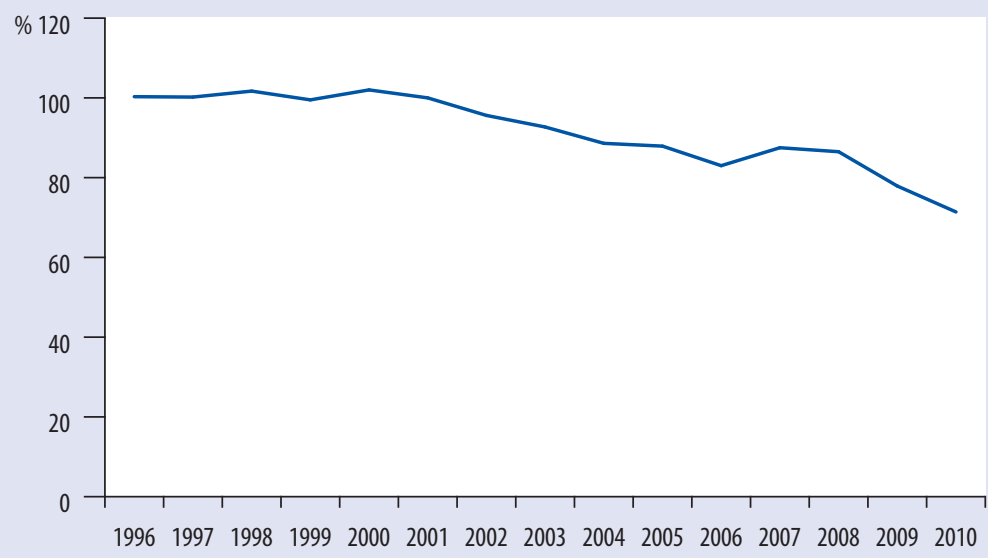

Bron: CBS, Enquête Beroepsbevolking 1996-2010

\subsection{De uitdagingen: vergrijzing in de Metalektro}

Een van de uitdagingen van de Metalektro voor de toekomst is de toenemende vergrijzing van het personeel. Deze vergrijzing wordt duidelijk in beeld gebracht door de leeftijdsverdeling van de werkende pensioenfondsdeelnemers in het PME, het pensioenfonds van de Metalektro (figuur I.5). Het zwaartepunt van de leeftijdsverdeling ligt bij werknemers van 40 jaar en ouder. Het aandeel van werknemers die 55 jaar of ouder zijn bedraagt I6\%, terwijl bijna de helft van de werknemers ouder is dan 45 . Op basis van de PME-cijfers is het niet mogelijk om deze leeftijdsopbouw naar sector te verdelen, maar uit CBS-cijfers afkomstig van de Enquête Beroepsbevolking blijkt dat de meeste oudere medewerkers in de basismetaal te vinden zijn. Daarentegen hebben bedrijven in de machine-industrie het laagste percentage 50-plussers. In de sectoren metaalproducten en transportmiddelen zijn verhoudingsgewijs de meeste jongere medewerkers werkzaam.

Het hoge percentage oudere werknemers stelt de bedrijven in de Metalektro voor twee grote uitdagingen. Ten eerste zal ervoor gezorgd moeten worden dat de oudere medewerkers op termijn vervangen kunnen worden door jonge medewerkers die in staat zijn om de werkzaamheden voort te zetten en daarbij ook de kennis over te nemen van het personeel dat met pensioen gaat. Dit is geen simpele taak, aangezien er nu al problemen zijn met het werven van geschikt personeel (zie hoofdstuk 3). Op termijn zal dit alleen maar moeilijker worden, zoals de arbeidsmarktprognoses, die voor de komende vijf jaar tekorten op de arbeidsmarkt voor technici voorspellen, laten zien (zie hoofdstuk 7). 


\section{Figuur 1.5}

Leeftijdsopbouw medewerkers Metalektro (werkzame leden PME), 2011

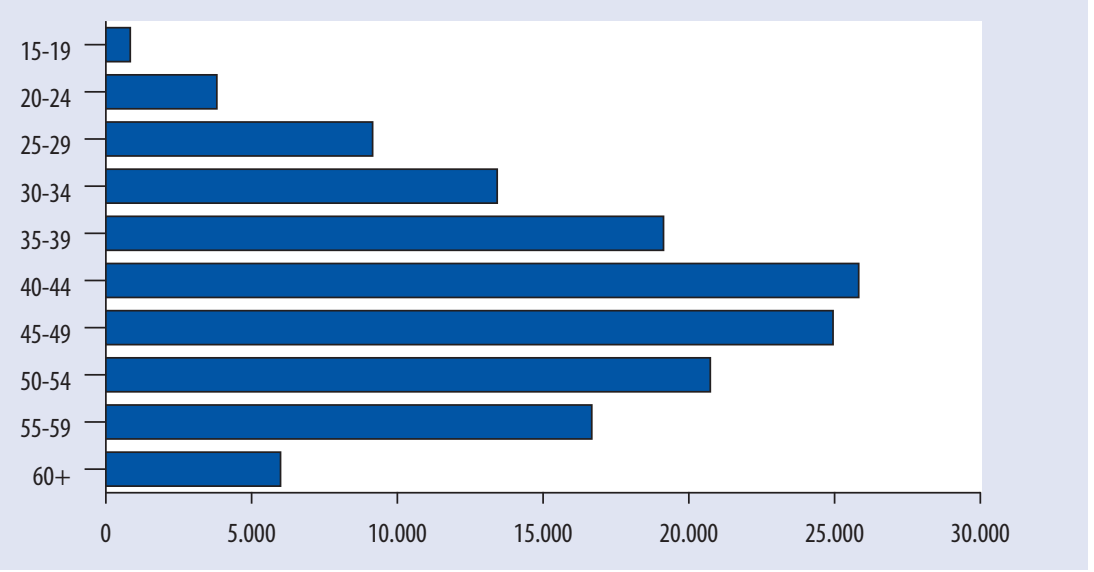

Bron: PME, berekening ROA

Een tweede uitdaging die veel bedrijven al opgepakt hebben, is het aanpassen van werkprocessen aan deze veranderde leeftijdsopbouw. Door te focussen op duurzame inzetbaarheid, en al vroegtijdig werkprocessen zowel voor jonge als ook oude werknemers aan te passen, moet het mogelijk worden om het personeel vitaler te houden en optimaal in te zetten. Ook de pensioengerechtigde leeftijd wordt steeds verder naar achteren geschoven. Voor zover metalektrobedrijven er in slagen hun medewerkers tot op latere leeftijd goed inzetbaar te houden, kan dit de toekomstige tekorten aan vakkrachten temperen. Het is aan de werknemers en de bedrijven om dit te realiseren. In hoofdstuk 6 zal nader worden ingegaan op de wijze waarop de Metalektro de duurzame inzetbaarheid van medewerkers probeert te vergroten.

\subsection{De uitdagingen: opleiden}

Duurzame inzetbaarheid vereist dat werknemers de ontwikkelingen in de voor hun werk vereiste kennis en vaardigheden bijhouden en zo mogelijk verder uitbouwen. Voor bedrijven is dit cruciaal om productief te kunnen werken en te kunnen blijven innoveren. Volgens de bedrijven worden belemmeringen op deze gebieden ook veroorzaakt doordat personeel onvoldoende niveau en/of motivatie heeft om deze continue veranderingen bij te houden. Dat hoeft niet per se leeftijdsgebonden te zijn, maar is vaak wel het gevolg van een veroudering van iemands kennis en vaardigheden. Daarom is het up-to-date houden van de competenties van medewerkers en het leren van nieuwe methoden of vaardigheden cruciaal voor de concurrentiepositie van de bedrijven. Dit kan gerealiseerd worden door het volgen van trainingen en cursussen, maar daarnaast wordt learning-on-the-job in veel functies steeds belangrijker. Dit 
betekent dat bedrijven veel aandacht moeten hebben voor de kennisoverdracht en -opbouw op de werkvloer.

Ook voor de werknemer zelf is opleiden een must om binnen het bedrijf en/of op de externe arbeidsmarkt voor werkgevers voldoende aantrekkelijk te blijven. In de CAO Metalektro is daarom sinds 20 Io het recht op twee opleidingsdagen ten behoeve van de persoonlijke ontwikkeling van de werknemer opgenomen. Werknemers kunnen deze dagen in overleg met hun werkgever voor hun eigen ontwikkeling inzetten, om zo aan hun employability binnen en buiten het bedrijf te werken.

Figuur I.6 schetst een beeld van de bekendheid met het recht op opleidingsdagen in de verschillende sectoren. Daarnaast wordt voor de bedrijven die bekend zijn met de opleidingsdagen, ook aangegeven bij welk deel van de werknemers deze dagen daadwerkelijk ingezet worden. Uit de figuur blijkt dat deze CAO-bepaling over het algemeen bekend is onder de metalektrobedrijven. Alleen bij de basismetaalbedrijven geeft $80 \%$ van de bedrijven aan met de regeling bekend te zijn. Opvallend is dat in geen enkele sector meer dan de helft van het personeel de opleidingsdagen daadwerkelijk gebruikt. Het gebruik van de opleidingsdagen varieert ook tussen de verschillende sectoren. Het meest worden deze gebruikt in de basismetaal en de transportmiddelenindustrie. In deze sectoren maken gemiddeld vier op de tien werknemers gebruik van de opleidingsdagen. Overigens varieert dit percentage ook binnen de sectoren sterk per bedrijf. Er zijn bedrijven waar het personeel nauwelijks gebruik maakt van deze regeling, maar er zijn ook bedrijven waar bijna elke werknemer de opleidingsdagen daadwerkelijk inzet voor het verbeteren van de employability.

\section{Figuur 1.6}

Bekendheid met de regeling voor opleidingsdagen (\% bedrijven), en percentage werknemers dat deze dagen gebruikt, 2011

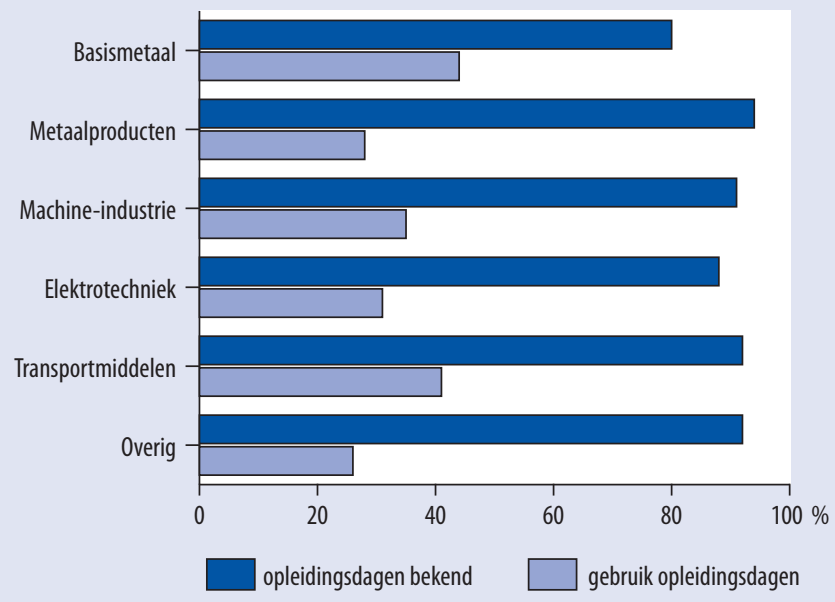

Bron: ROA, Arbeidsmarktmonitor Metalektro 2011 
Over het algemeen zijn de indicatoren voor de trainingsinspanning wisselvallig. Zoals in hoofdstuk 4 nader belicht zal worden, zijn de trainingsinspanningen in de Metalektro in 20II teruggelopen ten opzichte van 20I0. Dit blijkt zowel uit de daling van de trainingskosten als percentage van de loonsom als uit de daling van het percentage medewerkers dat in $201 \mathrm{I}$ een training volgde. Waarschijnlijk is dit mede het gevolg van het feit dat medewerkers in 2010 vanwege de terugval in de bedrijvigheid meer tijd hadden om scholing te volgen. Daarbij werd bovendien door verschillende bedrijven nog gebruik gemaakt van de deeltijd-WW regeling die tijdens de crisis werd ingesteld om hen in staat te stellen hun werknemers in dienst te kunnen houden. Aan deze regeling was een trainingsverplichting gekoppeld.

\subsection{De uitdagingen: innovaties}

Het belang van innovaties voor de Metalektro is groot. Een van de uitdagingen voor de sector is het continu ontwikkelen van nieuwe producten en diensten waarmee zij op hun huidige of nieuwe afzetmarkten kunnen concurreren. Daarnaast vormen innovaties in het productieproces in samenhang met de upgrading van de competenties van het personeel de drivers van de continue toename van de arbeidsproductiviteit in de sector. Hierdoor blijven bedrijven in staat om ondanks het relatief hoge loonniveau in Nederland internationaal competitief te presteren. Daarom is het voor metalektrobedrijven van groot belang om de toekomstige innovaties op het gebied van producten, diensten en processen op een hoog peil te houden. Hiervoor moeten de bedrijven continu investeren, verbeteren en veranderen, met als uitdaging om zo een continue stroom aan innovaties te creëren.

Figuur I.7 schetst een beeld van hoe bedrijven hun eigen innovatieniveau voor de toekomst zelf inschatten. Hierbij richten we ons op de meest innovatieve categorie: product-, diensten- en procesinnovaties die nieuw zijn voor de markt. De figuur geeft een overzicht van de door de bedrijven voor de komende vijf jaar verwachte innovaties in de verschillende metingen van de Arbeidsmarktmonitor Metalektro vanaf 2006. Uit de meest recente monitor blijkt dat de bedrijven in $201 \mathrm{I}$ een daling verwachten in de toekomstige productinnovaties. Daarentegen is er ten opzichte van 20 Io weer een opwaartse lijn zichtbaar in de diensten- en procesinnovaties. De figuur laat duidelijk zien dat het percentage bedrijven dat zich richt op productinnovaties die nieuw zijn voor de markt de afgelopen jaren sterk is teruggelopen. Dit lijkt een zorgelijke ontwikkeling. Daar staat echter tegenover dat het aantal bedrijven dat verwacht de komende jaren met nieuwe diensteninnovaties op de markt te komen zich weer herstelt op het niveau van voor de crisis. Dit wijst erop dat het realiseren van toegevoegde waarde door het verlenen van service en onderhoud een onomkeerbare trend in de sector is. Hierbij leveren bedrijven niet langer alleen een product, maar ook de bijbehorende services om daarmee optimaal te kunnen voorzien in de wensen van de afnemers. Het herstel van de procesinnovaties illustreert dat bedrijven beseffen dat zij zich alleen op 
hun afzetmarkten kunnen handhaven door steeds 'slimmer' te produceren en daarmee de arbeidsproductiviteit te verhogen.

Figuur 1.7

Verwachte innovaties (\% bedrijven, voor de komende vijf jaar), 2006-2011

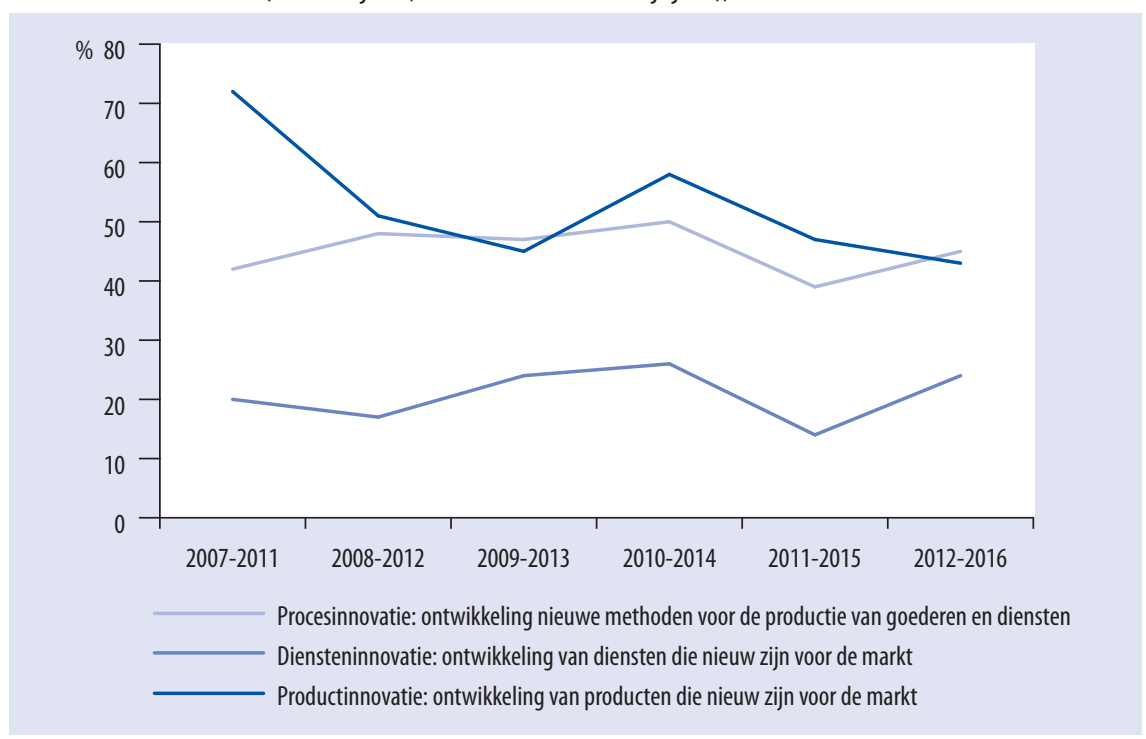

Bron: ROA, Arbeidsmarktmonitor Metalektro, 2006-2011

Zoals in hoofdstuk 5 aan bod zal komen, is de technologische innovatie onlosmakelijk verbonden met de inzet en/of organisatie van het personeel. Sociale innovatie waardoor slimmer gewerkt kan worden is niet alleen vaak een noodzakelijke voorwaarde om optimaal profijt te hebben van technologische innovaties, maar kan ook een klimaat bewerkstelligen dat technologische innovaties stimuleert. In hoofdstuk 5 zal worden aangetoond dat bedrijven die actief zijn op het gebied van sociale innovatie ook op technologisch gebied meer innovatief zijn. 



\section{Arbeidsmarktontwikkelingen in 2011}

De arbeidsmarktontwikkeling in de Metalektro in $201 \mathrm{I}$ was positief te noemen. In vergelijking met 2010 hebben meer bedrijven een hogere instroom van nieuwe medewerkers. In de tweede helft van het jaar neemt de instroom echter af. De uitstroom van personeel is in $20 I I$ lager dan de instroom; er was dus sprake van een toename van de werkgelegenheid in de sector. De mate waarin de werkgelegenheid toeneemt verschilt echter per regio. Bij de bedrijven die juist meer uitstroom dan instroom hebben, worden werknemers die het bedrijf verlaten niet vervangen, maar ook worden er vacaturestops ingesteld of worden tijdelijke contracten niet verlengd.

De overgrote meerderheid van de arbeidskrachten in de Metalektro heeft een vaste aanstelling. Het percentage werknemers met een vast dienstverband is in de loop van $20 I$ vrijwel niet veranderd. De omvang van de flexibele schil is het grootst in de uitvoerende technische functies en het kleinst in de leidinggevende technische en niet-technische functies. De omvang van de flexibele schil is in de Metalektro even groot als in andere bedrijfstakken binnen de sector industrie en energie, maar kleiner dan in de overige dienstensectoren. 


\subsection{Instroom van personeel in $\mathbf{2 0 1 1}$}

De positieve economische ontwikkeling in het begin van $201 \mathrm{I}$ vertaalde zich ook in hogere personeelsinstroom. In de tweede helft van 20 II vermindert de instroom, mede veroorzaakt door de onzekerheid over de toekomstige economische ontwikkeling (zie hoofdstuk I). Figuur 2.I vergelijkt de instroom van personeel in de eerste en tweede helft van $201 \mathrm{I}$ per functiecategorie. Terwijl in 2010 iets meer dan de helft van de bedrijven nieuw uitvoerend technisch personeel aannam, is dit in $201 \mathrm{I}$ ongeveer $60 \%$. Ten opzichte van 2010 zijn er ook meer bedrijven die personeel in leidinggevende technische functies hebben aangenomen: $21 \%$ in de eerste helft van 201 tegenover $31 \%$ in de tweede helft. Daarmee is dit de enige functiecategorie waarvoor de instroom in de tweede helft van 2oII toeneemt. Voor de overige functiecategorieën blijkt dat er in $20 I$ minder bedrijven waren die nieuwe medewerkers aantrokken dan in 2010 . Bij de ondersteunende niet-technische functies was de instroom in de tweede helft van 2010 min of meer gelijk aan de instroom in de eerste helft van $201 \mathrm{I}: 37 \%$ van de bedrijven heeft in de eerste helft van 201 i personeel in ondersteunende niet-technische functies aangesteld. Dat percentage is echter in de tweede helft van $201 \mathrm{I}$ gedaald naar $26 \%$, zoals blijkt uit de figuur. Ook het percentage bedrijven dat technisch opgeleide verkopers en leidinggevenden in niet-technische functies in de tweede helft van $201 \mathrm{I}$ heeft aangesteld is lager dan in de eerste helft van het jaar.

Figuur 2.1

Bedrijven met instroom naar functiecategorie (\% bedrijven), 2011

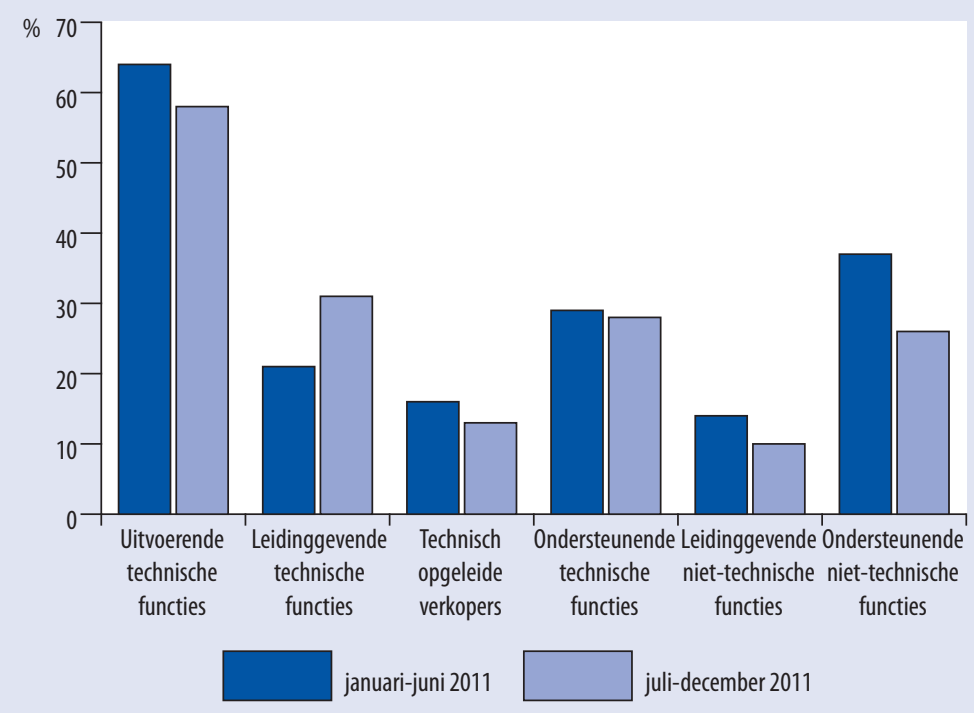

Bron: ROA, Arbeidsmarktmonitor Metalektro, 2011 
Figuur 2.2 geeft een overzicht van het percentage bedrijven dat voor de grootste functiecategorie, het uitvoerend technisch personeel, nieuwe medewerkers in dienst nam in de periode 2005 -20II. In deze periode trok jaarlijks gemiddeld $60 \%$ van de bedrijven nieuw personeel aan in deze functies. In de tweede helft van 2006 was dit percentage het hoogst. Toen nam $78 \%$ van de bedrijven nieuw uitvoerend technisch personeel aan. De periode van hoge instroom van 2006 tot 2008 eindigt met de intrede van de crisis. In de eerste helft van 2009 daalde het percentage bedrijven dat uitvoerend technisch personeel in dienst nam naar 39\%. De geleidelijke stijging van de instroom van uitvoerend technisch personeel die hierna plaatsvond kenmerkt het voorzichtige herstel van de economie tot de eerste helft van 20II. De afzwakking van de economische groei in de tweede helft van $201 \mathrm{I}$ wordt weerspiegeld door de afname van het percentage bedrijven waar sprake was van nieuwe instroom in de uitvoerende technische functies.

Figuur 2.2

Bedrijven met instroom van uitvoerend technisch personeel (\% bedrijven), 2005-2011

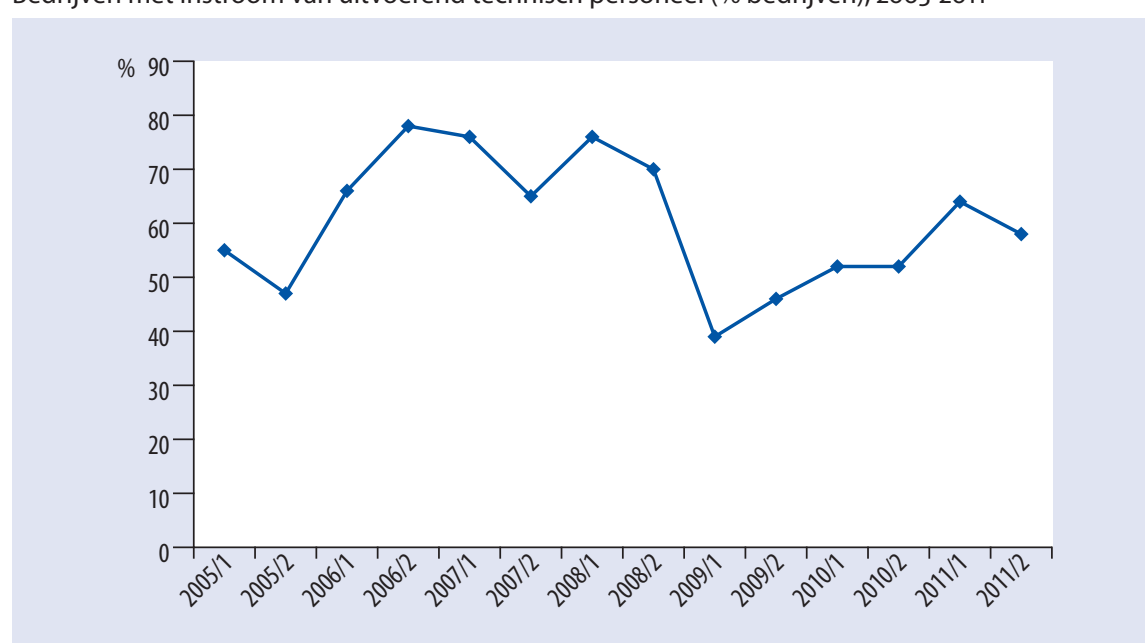

Bron: ROA, Arbeidsmarktmonitor Metalektro, 2005-2011

\subsection{Uitstroom van personeel in 2011}

In de eerste helft van $201 \mathrm{I}$ was het percentage bedrijven met uitstroom van personeel in vrijwel elke functiecategorie lager dan in de tweede helft van 20Io. Terwijl in 2010 een combinatie van vrijwillige veranderingen van baan en door bedrijven geïnitieerde krimp van het personeelsbestand in de uitstroomcijfers te vinden was, is dit in $201 \mathrm{I}$ veel minder het geval. Figuur 2.3 geeft een overzicht van het percentage bedrijven met uitstroom van werknemers in de verschillende functiecategorieën in respectievelijk de eerste en twee helft van 20II. In de tweede helft van het jaar blijkt het percentage bedrijven met uitstroom voor de meeste functies opnieuw af te nemen, ook al zijn de 
verschillen niet erg groot. Alleen voor leidinggevende technische functies blijkt het percentage bedrijven met uitstroom in de tweede helft van 201 hoger te zijn (23\%) dan in de eerste helft van het jaar (I8\%). Het percentage bedrijven met uitstroom van personeel in ondersteunende niet-technische functies lag zowel in de eerste als tweede helft van het jaar op iets meer dan $20 \%$. Het percentage bedrijven met uitstroom van personeel is het hoogst voor uitvoerende technische functies. In de tweede helft van $20 I$ gaf ruim de helft van de bedrijven aan te maken te hebben gehad met uitstroom voor deze functiegroep. Het percentage bedrijven met personeelsuitstroom is het laagst bij de technisch opgeleide verkopers (ruim IO\%) en leidinggevende niet-technische functies ( $13 \%$ in de eerste helft van 201 en $8 \%$ in de tweede helft van het jaar).

Figuur 2.3

Bedrijven met uitstroom naar functiecategorie (\% bedrijven), 2011

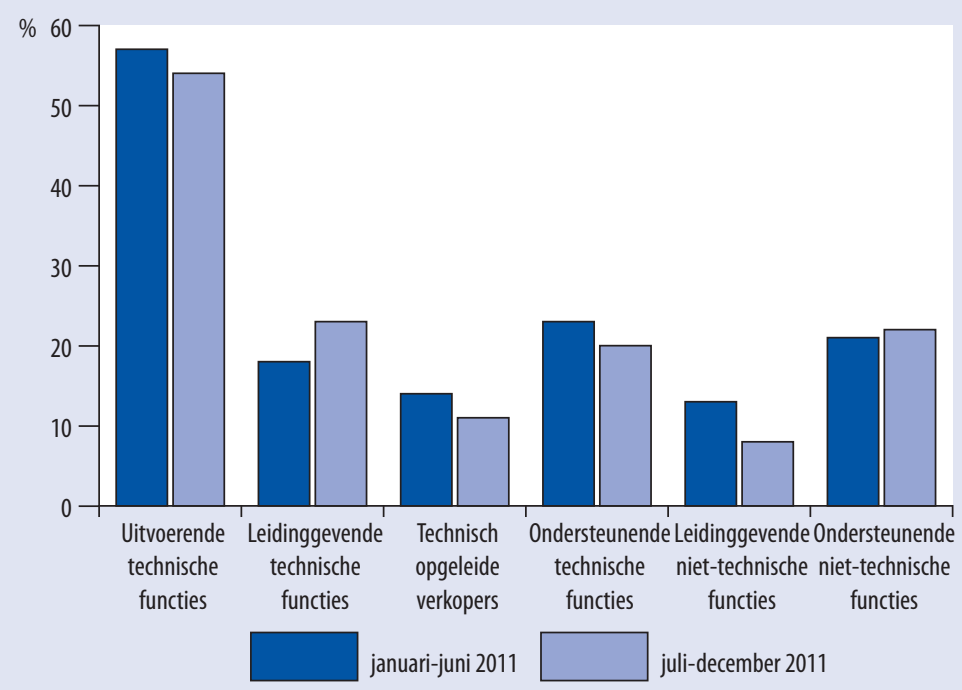

Bron: ROA, Arbeidsmarktmonitor Metalektro, 2011

De algemene ontwikkeling van de uitstroom over de tijd laat zich het best beschrijven aan de hand van het uitvoerend technisch personeel. Figuur 2.4 geeft voor deze grootste functiecategorie de ontwikkeling weer van het percentage bedrijven dat in de periode 2005-20II personeel zag vertrekken. Over de hele periode had gemiddeld $62 \%$ van de werkgevers te maken met personeelsuitstroom in de uitvoerende technische functies. De figuur laat zien dat het percentage bedrijven dat uitvoerend technisch personeel zag vertrekken tussen 2005 en 2006 toenam. Na een tijdelijke afname in vooral de tweede helft van 2007 , steeg het percentage bedrijven met uitstroom tot $75 \%$ in de eerste helft van 2008 toen de arbeidsmarkt zeer krap was. In de periode daarna nam het percentage bedrijven met uitstroom van uitvoerend technisch personeel geleidelijk af. 
De ontwikkeling van het percentage bedrijven met uitstroom van uitvoerend technisch personeel is vergelijkbaar met de instroom in figuur 2.2. Hier moet echter een belangrijke kanttekening bij geplaatst worden. De crisis die de Metalektro eind 2008 trof, leidde in de eerste helft van 2009 tot een scherpe daling van het percentage bedrijven met instroom, maar had weinig invloed op de uitstroom. Het percentage bedrijven waar uitvoerend technisch personeel uitstroomt neemt sinds 2008 structureel af. Dit wijst erop dat de uitstroom van personeel bij de metalektrobedrijven - in tegenstelling tot de instroom van nieuwe medewerkers - vrijwel niet beïnvloed wordt door de economische conjunctuur. Dit is het gevolg van minder vrijwillige mobiliteit van werknemers in tijden van crisis, er zijn dan minder kansen om van baan te veranderen, maar ook het beleid van bedrijven om onder meer met het oog op de verwachte tekorten aan technisch personeel het zittend personeel te houden.

Figuur 2.4

Bedrijven met uitstroom van uitvoerend technisch personeel (\% bedrijven), 2005-2011

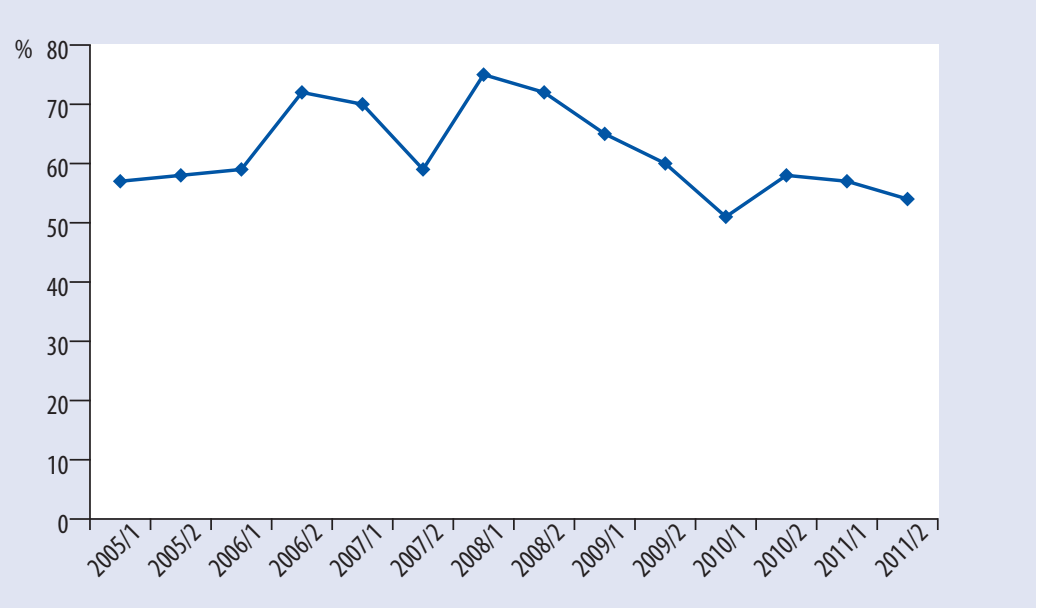

Bron: ROA, Arbeidsmarktmonitor Metalektro, 2005-2011

\subsection{Werkgelegenheidsontwikkelingen in 2011}

Figuur 2.5 geeft aan welke invloed de in- en uitstroom in bedrijven in $201 \mathrm{I}$ hebben gehad op de werkgelegenheid. De figuur laat zien dat de uitstroom van personeel 5,I\% bedroeg in de eerste helft van 20II. De instroom van nieuwe medewerkers was met $5,8 \%$ iets hoger. In de tweede helft van 20 II was de uitstroom van personeel I\%-punt hoger dan in de eerste helft van het jaar $(6,1 \%)$, maar ook de instroom was toen hoger dan in de eerste helft van het jaar $(7, \mathrm{I} \%)$. 


\section{Figuur 2.5}

Werkgelegenheidsmutaties: in- en uitstroom van werknemers (\% werknemers), 2011

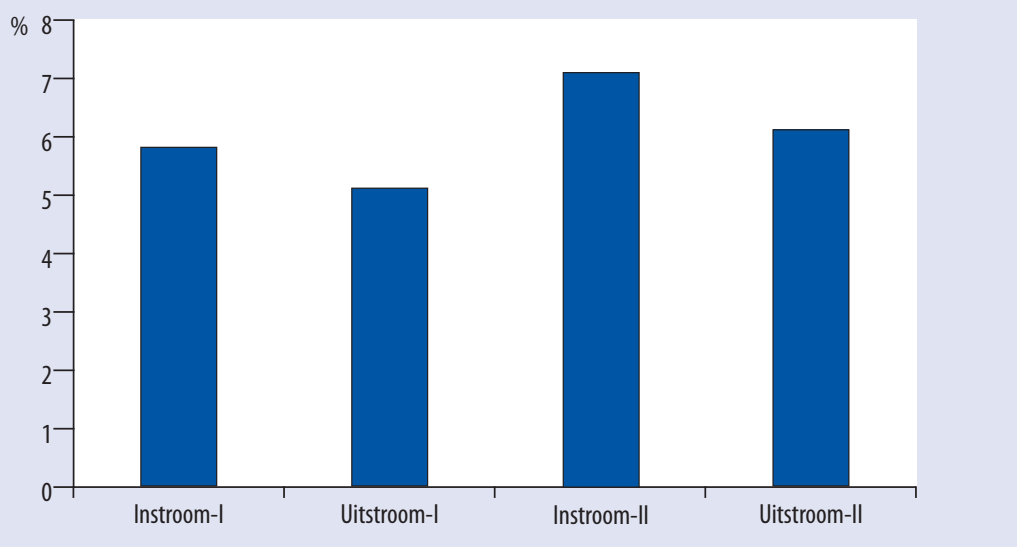

Bron: ROA, Arbeidsmarktmonitor Metalektro, 2011

\section{Regionale ontwikkeling van de werkgelegenheid}

De hogere uitstroom van werknemers in de tweede helft van 2011 wordt vooral veroorzaakt door de veranderingen in de personeelsuitstroom in het Westen van het land. De toename van de instroom van personeel in de tweede helft van 2011 is vooral toe te schrijven aan de werkgelegenheidsontwikkeling in het Westen en het Noordoosten. Per saldo is de werkgelegenheid in het Westen in de eerste helft van 2011 gekrompen met 1,3\%-punt, maar weer gestegen met 1,7\%-punt in de tweede helft van het jaar. In het Zuiden is de werkgelegenheid in de eerste helft van 2011 met 0,5\%-punt gegroeid, en in de tweede helft van het jaar verder doorgegroeid met 1,5\%-punt. In het Noordoosten is de werkgelegenheid in de eerste helft van 2011 met 4,5\%-punt gegroeid. In de tweede helft van het jaar bleef de werkgelegenheid in deze regio op hetzelfde niveau.

Werkgelegenheidsontwikkeling naar regio, 2011

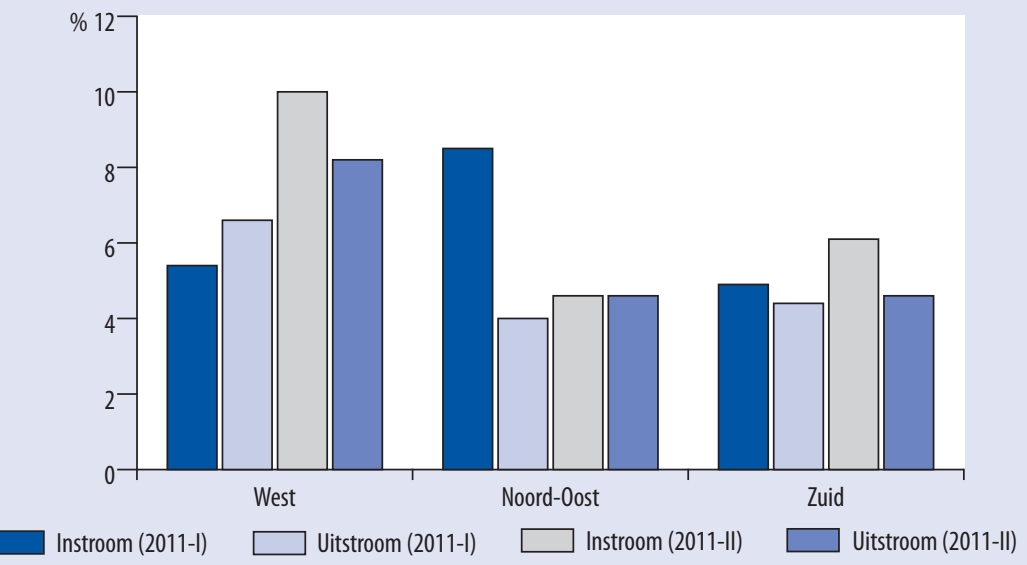

Bron: ROA, Arbeidsmarktmonitor Metalektro, 2011 
Aan de bedrijven is ook rechtstreeks gevraagd in welke mate zij te kampen hadden met een krimpende werkgelegenheid voor de verschillende functiecategorieën. Figuur 2.6 laat zien dat $20 \%$ van de bedrijven in de eerste helft van 20 II te maken had met krimpende werkgelegenheid in de uitvoerende technische functies. In de tweede helft van 20 II was dit iets hoger: $23 \%$. Ter vergelijking, het percentage bedrijven met een krimpende werkgelegenheid in de uitvoerende technische functies was in de eerste helft van 2010 nog $28 \%$, maar slechts $8 \%$ in de tweede helft van 2010 . Voor de andere functiecategorieën was de krimp in de tweede helft van 201 lager dan in de eerste helft van het jaar. Voor ondersteunende technische en niet-technische functies en voor leidinggevende niet-technische functies daalde het percentage bedrijven met krimpende werkgelegenheid in de tweede helft van $201 \mathrm{I}$ met ruim IO\%-punt ten opzichte van de eerste helft van het jaar. Voor de leidinggevende technische functies waren er in de eerste helft van $20 I$ minder bedrijven die aangaven met een krimpende werkgelegenheid te maken te hebben dan in 20IO. Dat percentage is in de tweede helft van $201 \mathrm{I}$

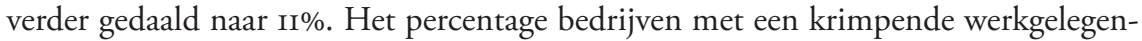
heid is het laagst bij de technisch opgeleide verkopers.

Figuur 2.6

Bedrijven met krimpende werkgelegenheid naar functiecategorie (\% van totaal aantal bedrijven), 2011

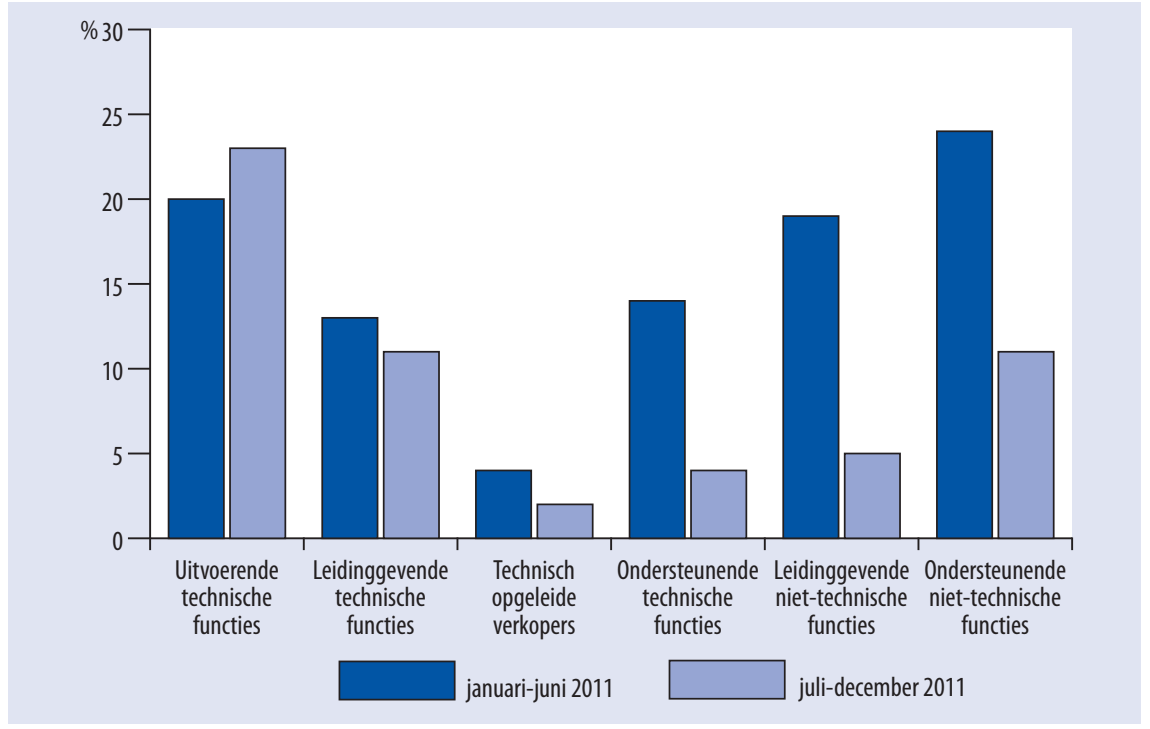

Bron: ROA, Arbeidsmarktmonitor Metalektro, 2011

Aan de bedrijven die in 201 kampten met een krimpende werkgelegenheid voor technisch personeel is gevraagd op welke wijze zij met deze krimp zijn omgegaan. Figuur 2.7 laat zien dat er in bijna de helft van deze bedrijven sprake was van een vacaturestop. Daarnaast is er een flinke groep die de aanstelling van medewerkers met tijdelijke contracten niet heeft verlengd, terwijl een bijna even grote groep de krimp realiseert 
door het niet vervangen van werknemers die met pensioen gaan. Deze belangrijkste maatregelen die ingezet worden om de werkgelegenheidskrimp in $201 \mathrm{I}$ te realiseren verschillen niet van die in 20I0, ook al worden deze alle drie in $201 \mathrm{I}$ minder vaak genoemd dan een jaar eerder. Dat veel bedrijven in $201 \mathrm{I}$ nog steeds een vacaturestop hebben wijst er op dat de economische crisis bij veel bedrijven in de Metalektro nog duidelijk voelbaar is. Dit blijkt ook uit het feit dat een kwart van de bedrijven met een krimpende werkgelegenheid in de technische functies zich genoodzaakt voelde om tot gedwongen ontslagen over te gaan. Dat werknemers het bedrijf op eigen initiatief verlaten $(29 \%)$, of naar andere functies binnen het bedrijf worden overgeplaatst $(28 \%)$ wordt in 2OII vaker genoemd dan in 20IO. Daarentegen wordt het actief stimuleren van werknemers om eerder met pensioen te gaan (I3\%) in $201 \mathrm{I}$ minder vaak als reden voor de krimp genoemd dan in 2010 .

Figuur 2.7

Wijze waarop de krimpende werkgelegenheid van technisch personeel wordt gerealiseerd (\% bedrijven met krimpende werkgelegenheid), 2010 en 2011

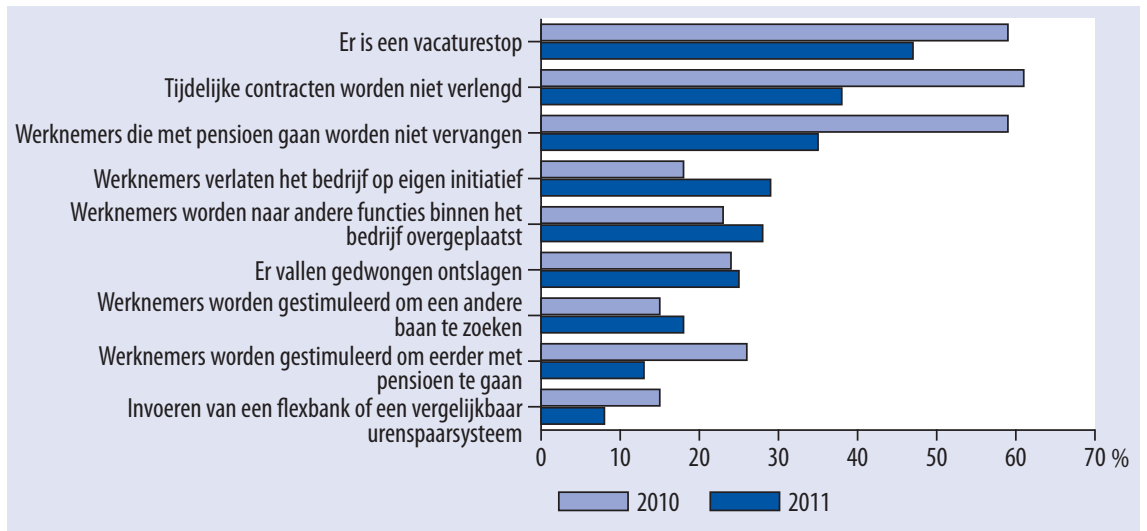

Bron: ROA, Arbeidsmarktmonitor Metalektro, 2010-2011

\subsection{Opbouw personeelsbestand in de Metalektro}

Naast de werknemers met een vast dienstverband maken de bedrijven in de Metalektro ook gebruik van arbeidskrachten met een tijdelijk contract en van flexibele arbeidskrachten die niet in dienst zijn van het bedrijf, zoals uitzendkrachten en gedetacheerden. Figuur 2.8 geeft voor elke functiecategorie weer welk deel van de werknemers een tijdelijk of flexibel contract heeft. In alle functies heeft de overgrote meerderheid echter een vaste aanstelling. Het percentage werknemers met een vast dienstverband vertoont slechts kleine veranderingen tussen de eerste en de tweede helft van 20II. Dit duidt er op dat bedrijven in deze economisch moeilijke tijd hun personeelsbeleid niet significant hebben aangepast. De grootste verandering betreft het percentage werknemers in uitvoerende technische functies met een vast contract dat 
gestegen is van $75 \%$ in de eerste helft van $201 \mathrm{I}$ naar $8 \mathrm{I} \%$ in de tweede helft van het jaar. Dit betekent dat voor deze functiegroep de omvang van de flexibele schil (tijdelijke en flexibele contracten) met 6\%-punt is afgenomen. Dit wordt vooral veroorzaakt door de afname van het percentage uitzendkrachten en gedetacheerden. Desalniettemin blijft de omvang van de flexibele schil het grootst in deze functiegroep.

\section{Figuur 2.8}

Percentage medewerkers met een tijdelijk of flexibel contract naar functiecategorie, 2011

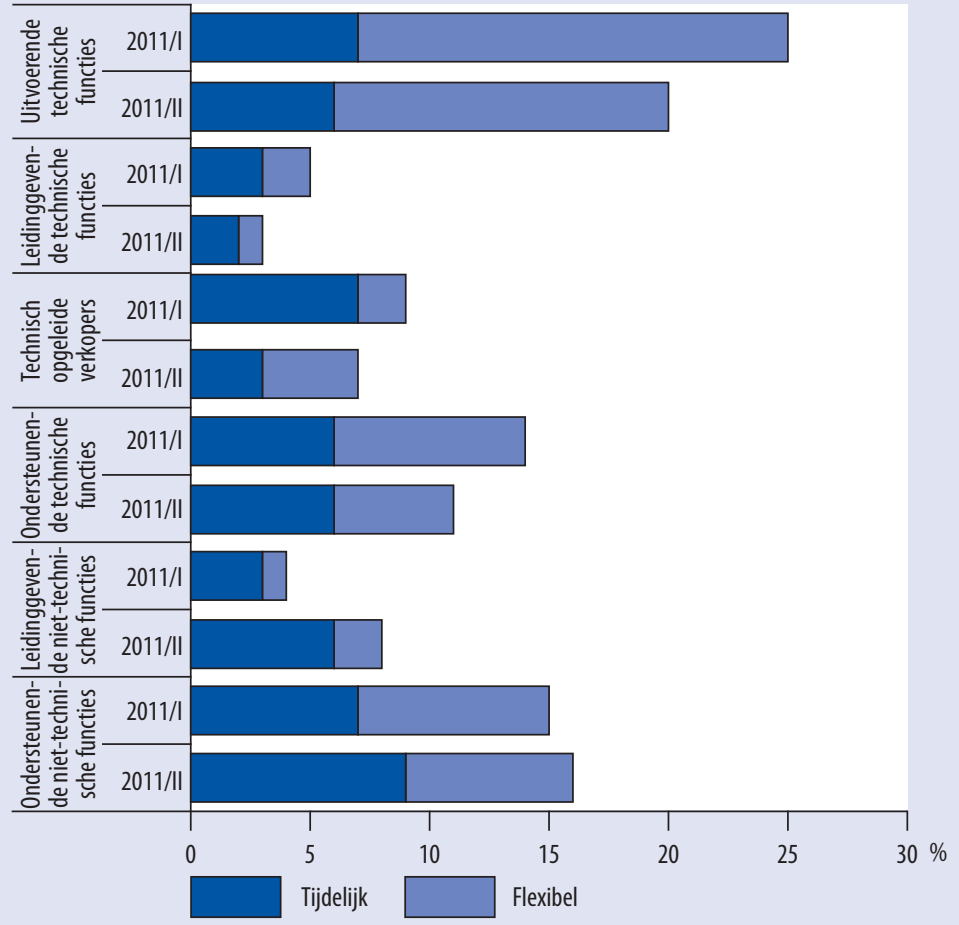

Bron: ROA, Arbeidsmarktmonitor Metalektro, 2011

De omvang van de flexibele schil is het kleinst voor de leidinggevende technische en niet-technische functies. Het percentage werknemers met leidinggevende niet-technische functies met een tijdelijk contract is echter in de loop van 201 toegenomen van $3 \%$ naar 6\%. Mede hierdoor is het percentage werknemers in een dergelijke functie met een vast dienstverband licht afgenomen. In de tweede helft van $201 \mathrm{I}$ had $97 \%$ van de werknemers in leidinggevende technische functies een vast dienstverband. Onder de technisch opgeleide verkopers heeft ruim 90\% van de werkenden een vast dienstverband. In deze functiegroep is het percentage werknemers met een tijdelijk dienstverband in de loop van $201 \mathrm{I}$ afgenomen, maar het percentage flexibele arbeidskrachten is toegenomen. In de ondersteunende technische functies is het percentage flexibele arbeidskrachten in de tweede helft van het jaar licht gedaald. 
HOOFDSTUK 2

\section{Flexibele schil in Metalektro}

Hoe verhoudt de omvang van de flexibele schil in de Metalektro zich tot die in andere sectoren van de economie? $0 \mathrm{p}$ basis van het Arbeidsaanbodpanel van het Sociaal Cultureel Planbureau is gekeken naar het gebruik van flexibele contracten in de Metalektro en andere sectoren in de periode 1998-2008. Flexibele contracten zijn daarbij gedefinieerd als tijdelijke contracten zonder uitzicht op een vaste aanstelling, uitzendcontracten, op- en afroepcontracten, gedetacheerden, e.d. De cijfers laten zien dat het gebruik van flexibele contractvormen in de Metalektro (ongeveer $6 \%$ ) gelijk is aan het gebruik daarvan in andere sectoren binnen de industrie en energie. In de overige sectoren vooral in de handel, horeca en overige dienstverlening - maakt men daarentegen veel vaker gebruik van flexibele contracten (11\%). 


\section{Vacatures en werving van personeel}

Het percentage bedrijven met openstaande vacatures is in $20 I 1$ duidelijk toegenomen. De meeste vacatures zijn voor de grootste functiecategorie; de uitvoerende technische functies. In het tweede deel van het jaar loopt de arbeidsmarktkrapte op. Dit blijkt uit de toegenomen gemiddelde duur die een vacature open staat. Afhankelijk van de functie die het betreft kunnen metalektrobedrijven verschillende wervingskanalen inschakelen. Bij de zoektocht naar uitvoerende en ondersteunende technici blijken uitzendbureaus het meest effectief, terwijl voor de werving van technisch opgeleide verkopers en leidinggevend technisch personeel beter gebruik gemaakt kan worden van de diensten van een commercieel werving-en selectiebureau. Een kwart van de bedrijven ondervindt in $201 \mathrm{I}$ veel problemen bij het aantrekken van technisch personeel. Sollicitanten blijken vaak niet over de juiste competenties te beschikken. In de praktijk leidt dit vooral tot een hogere werkdruk onder het zittende personeel. De meest genoemde maatregelen die bedrijven nemen bij tekorten aan technici zijn enerzijds het inschakelen van externe bureaus en anderzijds het flexibel inzetten van het zittende personeel. 


\subsection{Vacatures}

De arbeidsmarkt in de Metalektro trok in $201 \mathrm{I}$ weer aan. Ten opzichte van de eerste helft van 2010 is het percentage bedrijven dat vacatures heeft in de eerste helft van $20 I I$ in vrijwel elke functiecategorie toegenomen. De enige uitzondering hierop vormen bedrijven met vacatures voor ondersteunende niet-technische functies. Gezien het toegenomen aantal openstaande vacatures lijkt het erop dat de arbeidsmarkt begin 2OII iets krapper was dan in de eerste helft van 20 Io.

Figuur 3.I laat zien welk deel van de bedrijven in de eerste helft van 20 II openstaande vacatures had voor de verschillende functiecategorieën. Evenals in voorgaande jaren wordt er vooral gezocht naar medewerkers voor uitvoerende technische functies, de omvangrijkste functiecategorie in de Metalektro. Zes op de tien bedrijven hebben vacatures voor deze functies. Daarmee wordt in 201 bijna weer het niveau van voor de crisis bereikt. Destijds had tweederde van de bedrijven vacatures voor uitvoerende technici. Daarnaast hadden in $201 \mathrm{I}$ drie op de tien bedrijven vacatures voor ondersteunende technici en twee op de tien voor respectievelijk ondersteunende niettechnici, technisch opgeleide verkopers en leidinggevende technici. Evenals in andere jaren zijn er relatief weinig vacatures voor leidinggevenden in niet-technische functies. Overigens zijn er regionale verschillen in de mate waarin bedrijven vacatures hebben. Zo blijft in $201 \mathrm{I}$ de vraag naar uitvoerende technici in de regio Noord/Oost achter bij de rest van het land, terwijl in het Westen minder vraag naar technisch opgeleide verkopers is.

\section{Figuur 3.1}

Percentage bedrijven met vacatures, naar beroepscategorie van de werknemer, 2011

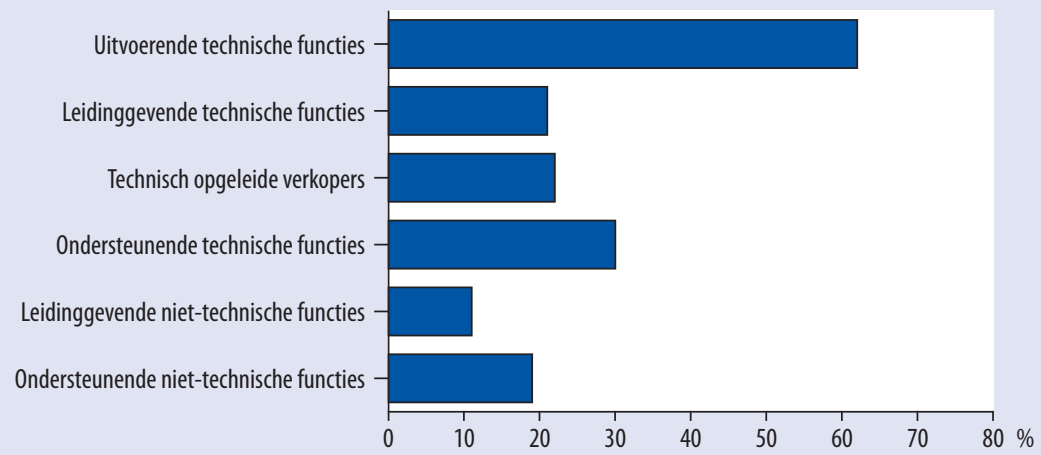

Bron: ROA, Arbeidsmarktmonitor Metalektro, 2011 


\section{Vacatureduur}

De arbeidsmarktkrapte kan niet alleen afgelezen worden aan het feit óf er veel vacatures open staan, maar ook aan hoelang deze open staan. Hoe schaarser het arbeidsaanbod, hoe langer het zal duren voordat een vacature ingevuld kan worden. Op deze wijze is de gemiddelde tijd dat vacatures open staan een belangrijke indicator voor de krapte op de arbeidsmarkt voor technici.

Tussen 2008 en 2010 werd de arbeidsmarkt duidelijk ruimer. Dit blijkt uit het feit dat een steeds groter deel van de bedrijven er in slaagde om vacatures binnen drie maanden in te vullen. In de eerste helft van 2010 had $72 \%$ van de bedrijven er gemiddeld minder dan drie maanden voor nodig om hun vacatures in te vullen. Sindsdien slagen bedrijven er echter duidelijk minder in om vacatures binnen drie maanden in te vullen en loopt de gemiddelde vacatureduur weer op. Met name in de tweede helft van 20 II nam de arbeidsmarktkrapte behoorlijk toe. Het aantal bedrijven dat de zoektocht naar technisch personeel binnen drie maanden succesvol afrondde, daalde aanzienlijk. Slaagden hier in de eerste helft van het jaar nog 6 op de io bedrijven in, in de tweede helft van het jaar was dit gedaald tot slechts een derde van de bedrijven. Vaak liep de gemiddelde tijd dat vacatures open stonden zelfs op naar meer dan zes maanden.

Figuur 3.2

Duur openstaande vacatures voor technisch personeel, 2008-2011

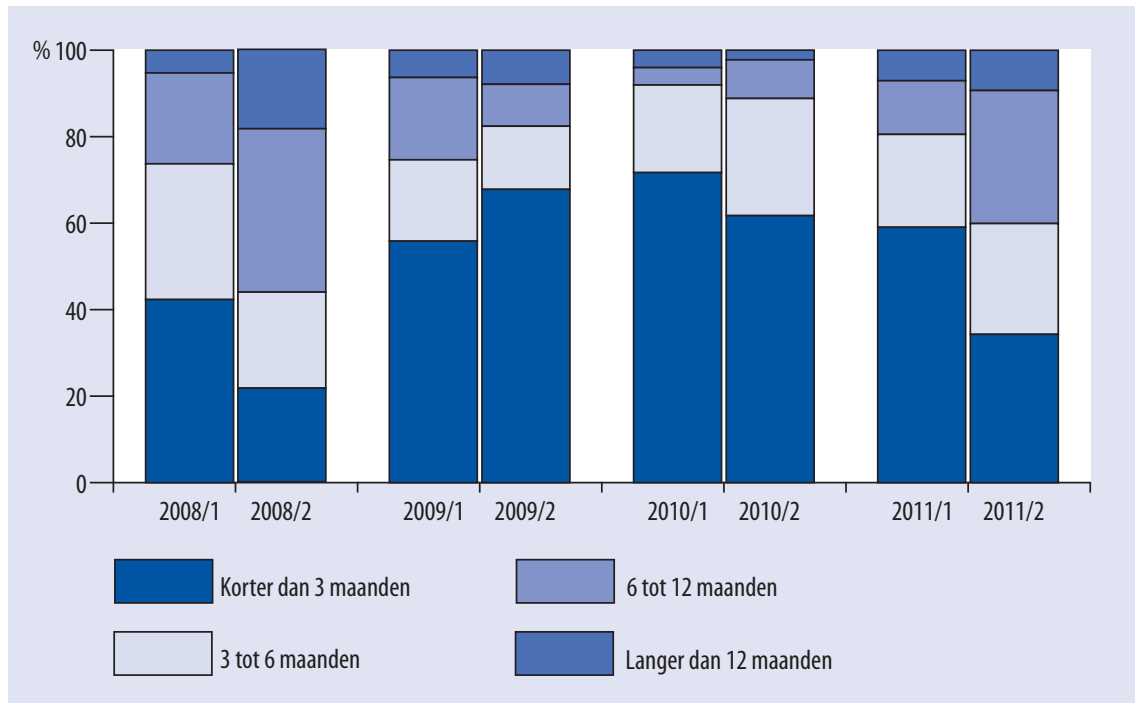

Bron: ROA, Arbeidsmarktmonitor Metalektro, 2008-2011 


\section{Functiecategorie}

Eerder gaf figuur 3.I al per functiecategorie weer welk deel van de bedrijven vacatures open had staan. Het grootste deel van het totaal aantal vacatures in de Metalektro bestaat uit uitvoerende technische functies, zo blijkt uit figuur 3.3. Evenals in 2010 gaat het om circa zes op de tien vacatures. Daarnaast zijn er met name vacatures voor ondersteunende functies en leidinggevende technische functies. Deze cijfers laten overigens geen grote verschuivingen zien in vergelijking met 20IO. Ook blijkt de verdeling van het aantal vacatures over de verschillende functiecategorieën in grote lijnen overeen te komen met de functiestructuur van de metalektrobedrijven. Alleen het aantal vacatures voor ondersteunende niet-technische functies is aanzienlijk lager dan verwacht zou worden op basis van de omvang van deze functiecategorie. Ook zijn er geen grote regionale verschillen. Wel blijkt dat er in het Noordoosten verhoudingsgewijs veel openstaande vacatures voor ondersteunende technici zijn.

\section{Figuur 3.3}

Verdeling totaal aantal openstaande vacatures naar functiecategorie, 2011

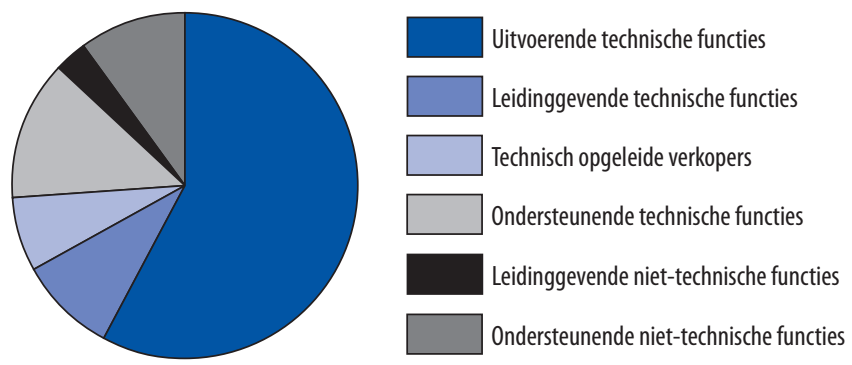

Bron: ROA, Arbeidsmarktmonitor Metalektro, 2011

Om een beter beeld te schetsen van het soort functies waarvoor medewerkers gezocht worden, wordt in de figuren 3.4 en 3.5 een overzicht gegeven van de specifieke functies waarvoor in de tweede helft van 20 II vacatures openstonden. Hierbij concentreren wij ons op de twee functiecategorieën met de meeste vacatures: de uitvoerende en ondersteunende technische functies. De bedrijven die op zoek waren naar geschikte uitvoerende technici zochten in het bijzonder naar pijpverwerkers, lassers en machinaal verspaners. Metalektrobedrijven die ondersteunend technisch personeel wilden aantrekken waren vooral op zoek naar personeel op $\mathrm{MBO}+$-niveau. Verder waren werkvoorbereiders en proces engineers in $201 \mathrm{I}$ gewilde arbeidskrachten. 
Figuur 3.4

Aantal openstaande vacatures voor uitvoerende technici in de Metalektro, 2011

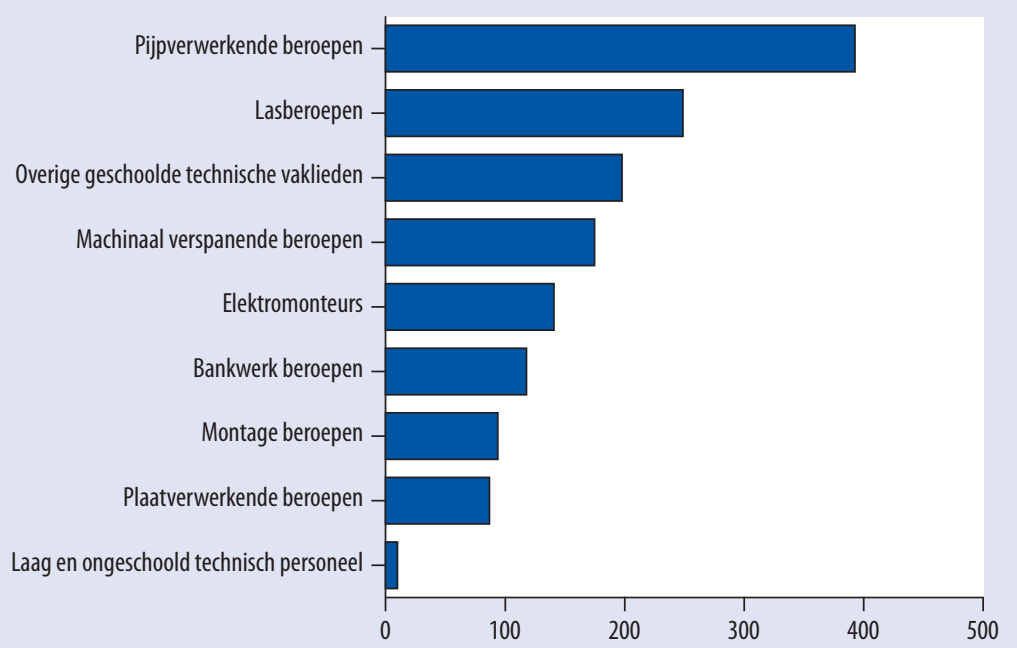

Bron: ROA, Arbeidsmarktmonitor Metalektro, 2011

Figuur 3.5

Aantal openstaande vacatures voor ondersteunende technici in de Metalektro, 2011

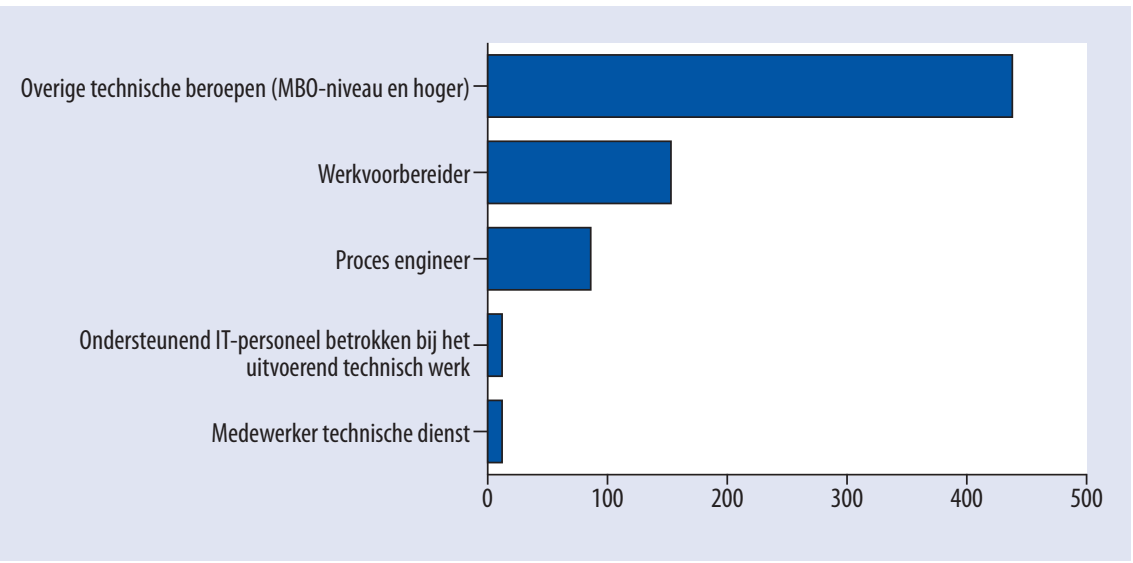

Bron: ROA, Arbeidsmarktmonitor Metalektro, 2011

De ontstaansreden van een vacature zegt iets over het beleid dat bedrijven voeren. Daarbij is het interessant om te kijken in hoeverre bedrijven op dit punt een proactief of reactief beleid voeren. Wanneer bedrijven aangeven dat vacatures zijn ontstaan doordat zij anticiperen op toekomstige veranderingen, dan heeft het bedrijf een proactief vacaturebeleid. Plaatsen bedrijven daarentegen een vacature als duidelijk is 
dat de functie snel vacant is, dan is er sprake van een reactief vacaturebeleid. Figuur 3.6 laat de belangrijkste ontstaansredenen zien van vacatures voor technisch personeel in de tweede helft van 20II. Daarbij wordt een onderscheid gemaakt tussen vacatures die ontstaan doordat bedrijven een reactief dan wel proactief vacaturebeleid voeren.

Hoewel de vergrijzingsproblematiek in de Metalektro vaak onderwerp van gesprek is, ontstaan er nog steeds betrekkelijk weinig vacatures doordat medewerkers met pensioen gaan. Veel vaker is er sprake van een toename van de hoeveelheid werk en vrijwillig vertrek van personeel. Meer dan twee derde van de openstaande vacatures voor technici in $201 \mathrm{I}$ was het gevolg van een toename van de hoeveelheid werk. Bij een toename van de hoeveelheid werk is er ook het vaakst sprake van een proactief vacaturebeleid. Het aantal bedrijven dat in het vacaturebeleid anticipeert op een verwachte toename van het werk is dan ook groter dan het aantal bedrijven dat de vacatures pas plaatst op het moment dat de hoeveelheid werk is toegenomen. Bij meer dan de helft van de bedrijven was er in 20II ook sprake van vacatures voor technisch personeel, omdat het vrijwillige vertrek van personeel opgevangen moet worden. Deze vacatures worden in verreweg de meeste gevallen pas geplaatst nadat technici het bedrijf vrijwillig verlaten hebben.

Minder dan 5\% van de bedrijven slaagt er bij deze vacatures in om een proactief vacaturebeleid te voeren. Hieruit blijkt dat bedrijven meestal moeilijk kunnen inschatten welke medewerkers het bedrijf gaan verlaten. Bij bijna $40 \%$ van de bedrijven ontstaan er ook vacatures omdat medewerkers met pensioen gaan. Daarbij geeft de helft van de bedrijven aan dat ze bij deze vacatures een proactief beleid voeren. Bij vacatures voor functies die ontstaan door interne functieveranderingen slagen de metalektrobedrijven er daarentegen weer veel minder goed in om een proactief vacaturebeleid te voeren. Dit illustreert dat bedrijven doorgaans veel beter zicht hebben op welke medewerkers er binnen afzienbare tijd met pensioen zullen gaan dan welke interne verschuiven er plaats gaan vinden en voor welke functies er daardoor nieuwe mensen zullen moeten worden geworven. Dit wijst er op dat er bij veel bedrijven nog onvoldoende sprake is van een goed loopbaanmanagement. 


\section{Figuur 3.6}

Ontstaansreden van vacatures voor technici; bedrijven die proactief of reactief handelen (\%), julidecember 2011

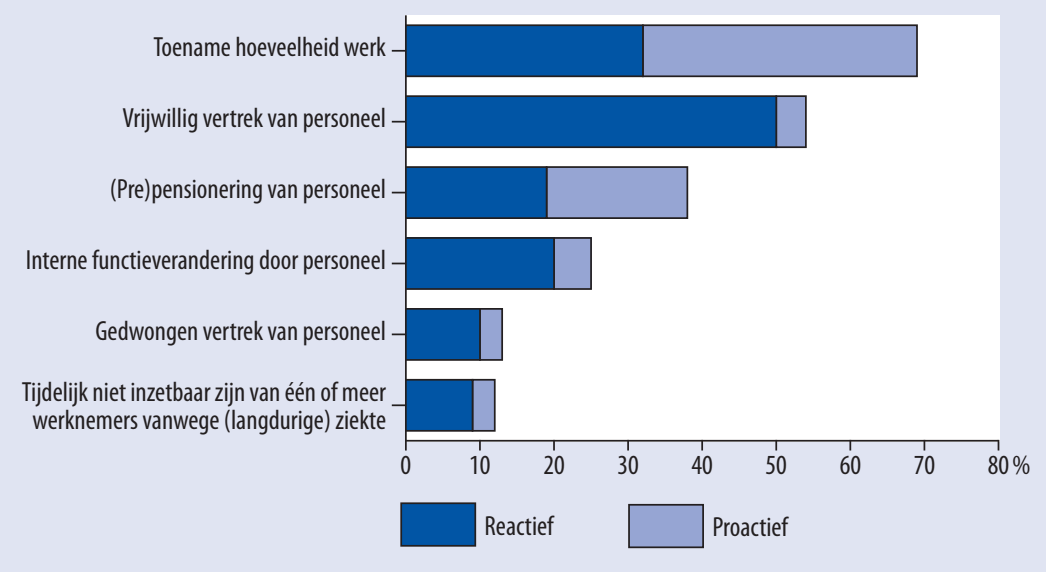

Noot: De ontstaansredenen 'het tijdelijk niet inzetbaar zijn van één of meer werknemers om andere redenen dan ziekte' en 'het minder werken door één of meer werknemers' zijn eveneens als antwoordcategorie opgenomen, maar worden door minder dan $5 \%$ van de bedrijven genoemd. Bron: ROA, Arbeidsmarktmonitor Metalektro, 2011

\subsection{Effectieve wervingskanalen}

Afhankelijk van de in te vullen vacature kunnen bedrijven kiezen welke wervingskanalen zij inzetten om de doelgroep te benaderen. Daarbij kan ook worden gekozen voor een combinatie van verschillende wervingskanalen om de attentiewaarde onder potentiële sollicitanten te vergroten. Bij deze overweging moet een afweging gemaakt worden van het verwachte succes van een wervingskanaal en het kostenplaatje dat dit met zich meebrengt. De kosten van de verschillende wervingskanalen kunnen doorgaans tamelijk eenvoudig inzichtelijk gemaakt worden, maar de effectiviteit van de verschillende kanalen is niet altijd even duidelijk. Bovendien is dit sterk afhankelijk van het type functie waarvoor de vacature open staat. Moet er bijvoorbeeld een uitvoerende technische functie ingevuld worden of een leidinggevende functie waarvoor niet direct technische expertise vereist is? Het spreekt voor zich dat antwoorden op vragen als deze in sterke mate bepalen welk wervingskanaal het best ingezet kan worden.

Wij beperken ons hier tot de technische functies. Aan de bedrijven is gevraagd om voor de verschillende technische functies aan te geven wat in hun ogen het meest effectieve wervingskanaal is. In figuur 3.7 worden de meest effectieve wervingskanalen voor uitvoerende en ondersteunende technici weergegeven, terwijl figuur 3.8 laat zien welke wervingskanalen doorgaans het meest geschikt worden geacht voor het 
aantrekken van technisch opgeleide verkopers en leidinggevende technici. Voor beide figuren geldt dat alleen de meest genoemde wervingskanalen gepresenteerd worden.

Figuur 3.7

Meest effectieve wervingskanalen voor uitvoerende en ondersteunende technici (\% bedrijven), 2011

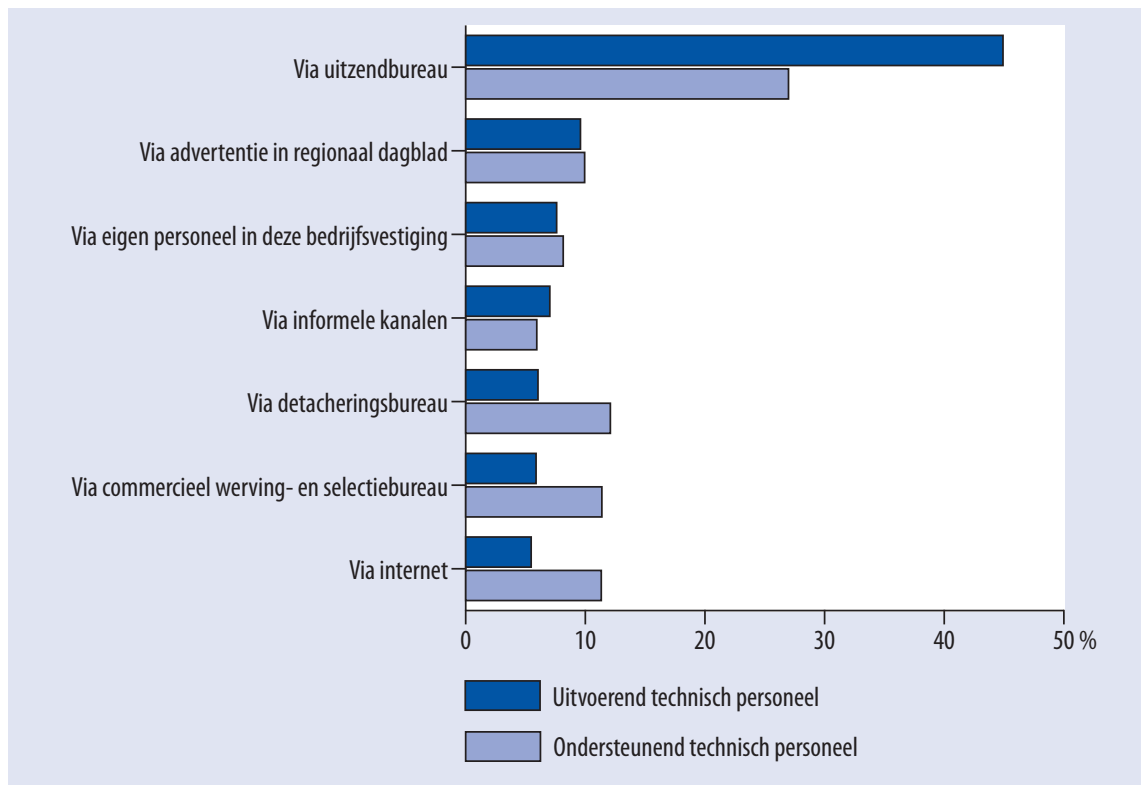

Noot: Ook andere wervingskanalen waren als antwoordcategorie opgenomen, maar worden door minder dan 5\% van de bedrijven genoemd: advertenties in landelijke dagbladen, advertenties in vakbladen, open sollicitaties, via personeel in andere bedrijfsvestiging(en), UWVWERKbedrijf (voormalig $(W \mathrm{I})$, externe relaties en de scholen.

Bron: ROA, Arbeidsmarktmonitor Metalektro, 2011

In 2011 gaven de metalektrobedrijven aan dat zij het uitzendbureau het meest effectieve wervingskanaal vinden voor het aantrekken van zowel uitvoerende als ondersteunende technici. Daarbij is er volgens de bedrijven tussen beide functiecategorieën echter wel sprake van een behoorlijk verschil in de effectiviteit van uitzendbureaus. Voor het aantrekken van ondersteunend technisch personeel geeft iets meer dan een kwart van de bedrijven aan dat het uitzendbureau het meest effectieve wervingskanaal is. Voor het aantrekken van uitvoerende technici is dit zelfs $45 \%$. Bij vacatures voor ondersteunende technici vinden bedrijven ook het inschakelen van een detacheringsbureau of een commercieel werving- en selectiebureau, het zoeken middels internet of het plaatsen van een advertentie in een regionaal dagblad vaker effectief. Deze vier kanalen worden elk door ongeveer IO\% van de bedrijven als het beste wervingskanaal voor deze functies gezien. Bij uitvoerende technische functies lijkt, op het uitzendbureau na, het plaatsen van advertenties in regionale dagbladen het meest effectief te zijn. 


\section{Wie bepaalt het wervingskanaal?}

De keuze voor wervingskanalen wordt in één bedrijf bepaald door de leidinggevende die voor de vacature verantwoordelijk is. Uit het brede scala aan wervingskanalen (uitzendbureaus, werving- \& selectiebureaus, headhunters, detacheringsbureaus voor technici, informele kanalen) wordt vaak gekozen voor het wervingskanaal dat de leidinggevende het meest voor de hand liggend vindt. Zeker als leidinggevenden hun eigen netwerk voor werving inzetten.

Bij vacatures voor leidinggevend technisch personeel en technisch opgeleide verkopers, boeken bedrijven doorgaans het meeste resultaat met andere wervingskanalen. Ook hier springt in 20 II één wervingskanaal er duidelijk uit. Voor deze hogere functies zijn het niet de uitzendbureaus maar de commerciële werving- en selectiebureaus die voor de metalektrobedrijven het meest effectief zijn. Dit geldt voor het invullen van vacatures voor zowel leidinggevende technici als technisch opgeleide verkopers (figuur 3.8).

\section{Figuur 3.8}

Meest effectieve wervingskanalen voor leidinggevend technisch personeel en technisch opgeleide verkopers (\% bedrijven), 2011

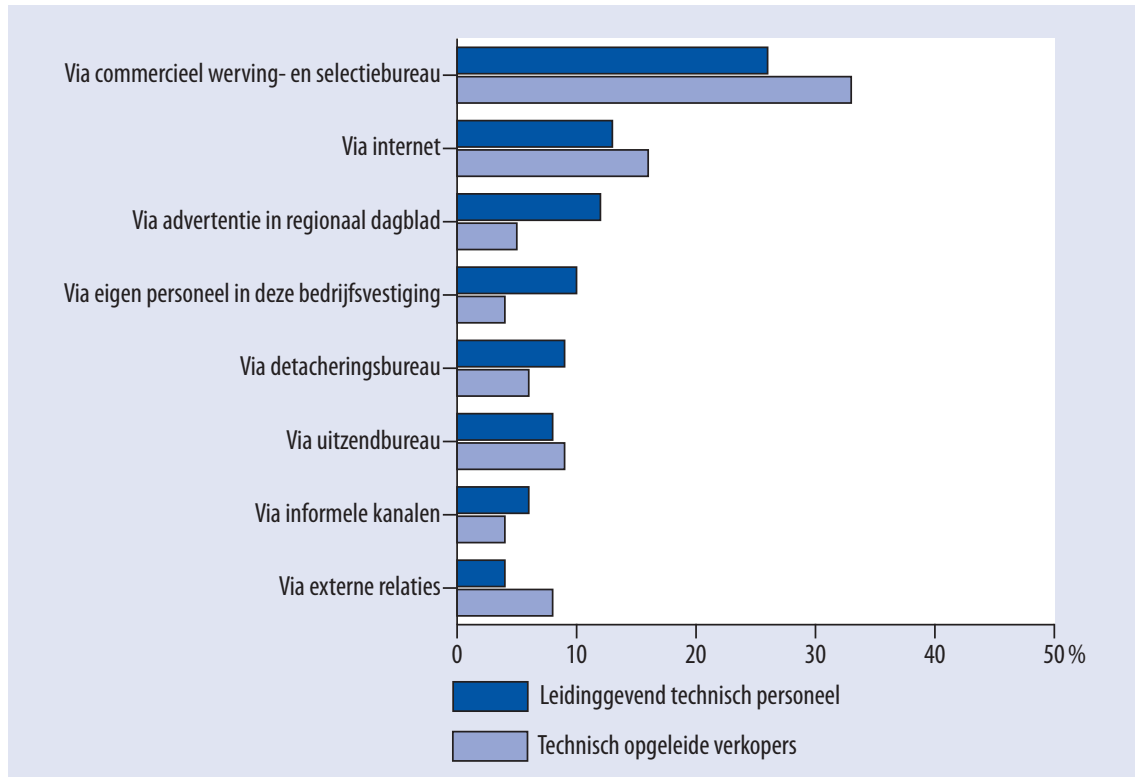

Noot: De navolgende wervingskanalen zijn eveneens als antwoordcategorie opgenomen, maar worden door minder dan $5 \%$ van de bedrijven genoemd: via school/opleiding, UWV WERKbedrijf (voormalig CWI), via personeel in andere bedrijfsvestiging(en), advertenties in vakbladen, advertenties in landelijke dagbladen, en open sollicitaties.

Bron: ROA, Arbeidsmarktmonitor Metalektro, 2011 
Een kwart van de bedrijven zegt dat het commercieel werving- en selectiebureau het meest effectieve wervingskanaal is bij vacatures voor leidinggevend technisch personeel. Voor het aantrekken van technisch opgeleide verkopers vindt I op de 3 bedrijven dit het meest effectieve wervingskanaal. Het is ook interessant om te zien dat het internet zowel voor leidinggevend technisch personeel als voor technisch opgeleide verkopers als het op één na meest effectieve wervingskanaal wordt gezien. Daarnaast wordt het plaatsen van advertenties in regionale dagbladen door I op de 8 bedrijven als het meest effectieve wervingskanaal gezien bij vacatures voor leidinggevend technisch personeel.

\section{Internet als wervingskanaal}

Internet speelt een belangrijke rol in de personeelswerving. In de Quickscan van december 20 II stond, naast de rol van sociale media, het gebruik van internet als wervingskanaal centraal. Bedrijven kregen de volgende stelling voorgelegd:

"Het internet is een belangrijk wervingskanaal voor het aantrekken van nieuw personeel”.

Daarbij varieerden de antwoordmogelijkheden van 'helemaal niet mee eens' tot 'helemaal mee eens'. De helft was het eens met deze stelling. Daarbij waren bijna 3 op de Io bedrijven het hier "helemaal mee eens". Vooral grote bedrijven en bedrijven in de machinebouw hechten veel waarde aan het internet als wervingskanaal. Slechts een kleine IO\% van de bedrijven vindt het internet geen belangrijk wervingskanaal.

Dat een aanzienlijk deel van de bedrijven positief is over het gebruik van internet als wervingskanaal, wil nog niet zeggen dat deze bedrijven het internet ook daadwerkelijk inzetten om technisch personeel aan te trekken. Ook kunnen bedrijven het internet weliswaar als een belangrijk wervingskanaal zien, maar een ander wervingskanaal in de praktijk nog steeds effectiever vinden. Figuur 3.9 laat zien hoe het aantal bedrijven dat het internet als het meest effectieve wervingskanaal ziet voor het aantrekken van technische medewerkers zich de afgelopen jaren ontwikkeld heeft. Daarbij wordt een onderscheid gemaakt tussen vacatures voor de verschillende technische functiecategorieën. De figuur laat zien dat het percentage bedrijven dat het internet als het meest effectieve wervingskanaal ziet aanzienlijk lager ligt dan het percentage bedrijven dat het internet in de Quickscan een belangrijk wervingskanaal noemde. Hieruit blijkt dat het internet door veel bedrijven nog steeds gezien wordt als een nuttige betrekkelijk goedkope aanvulling op andere meer effectieve wervingskanalen.

In de afgelopen vijf jaar wordt het internet het minst vaak als het meest effectieve wervingskanaal gezien voor het aantrekken van uitvoerende technici. Daarbij valt met name de forse daling in $2008 \mathrm{op}$. Voor het vervullen van vacatures in de drie overige technische functiecategorieën zijn werkgevers vaker positief over de effectiviteit van het internet als wervingskanaal. Daarbij is het opmerkelijk dat er - zoals misschien 
verwacht zou worden - geen sprake is van een stijgende trend. Integendeel, er lijkt eerder sprake te zijn van een lichte daling van het enthousiasme van de bedrijven om via internet aan nieuwe medewerkers te komen. Er lijkt derhalve nog steeds geen sprake te zijn van een echte 'take-off' van het internet als wervingskanaal. Mogelijk kan de opkomst van sociale media hier de komende jaren verandering in brengen als bedrijven hier meer ervaring gaan opdoen.

\section{Figuur 3.9}

Internet als meest effectieve wervingskanaal genoemd, naar technische functiecategorie, 2007-2011

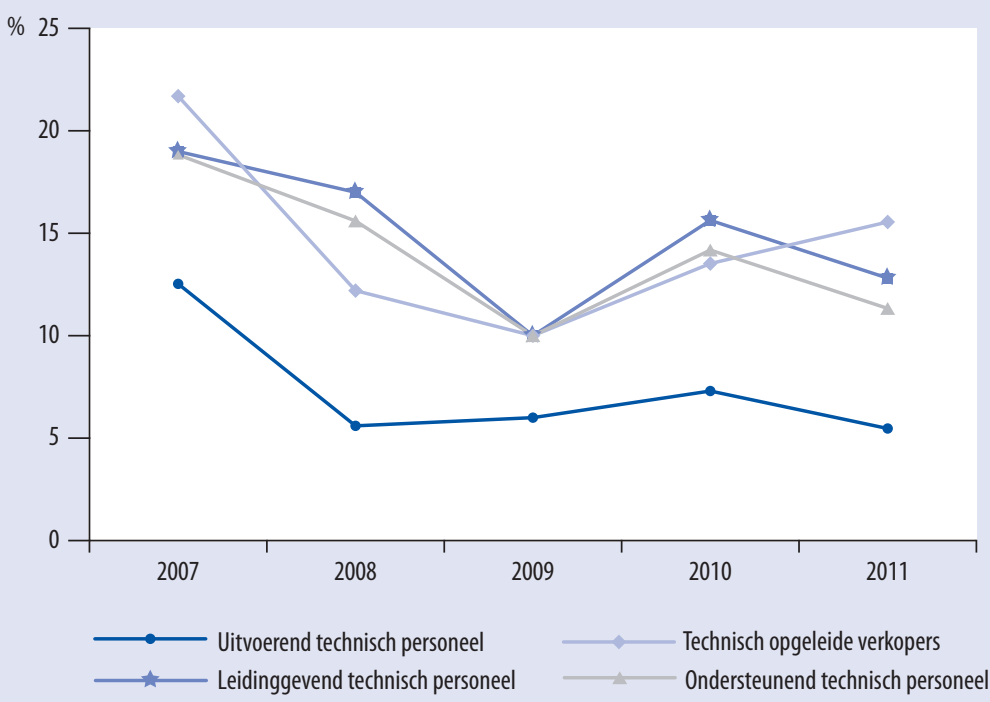

Bron: ROA, Arbeidsmarktmonitor Metalektro, 2007-2011

\section{Ben ik als werkgever aantrekkelijk genoeg voor de nieuwe generatie medewerkers?}

Een bedrijf dat klaar is voor die nieuwe generatie voldoet volgens een P\&0'er van een metalektrobedrijf aan de volgende criteria:

- gebruikt de communicatiekanalen van de nieuwe generatie (social media);

- biedt flexibiliteit (o.a. in werktijden, zelfroosteren);

- beseft dat de nieuwe generatie naast geld ontwikkelmogelijkheden erg belangrijk vindt

- biedt zijn medewerkers vrijheid;

- heeft een'lossere' managementstijl die gebaseerd is op vertrouwen in de medewerkers. 


\subsection{Wervingsproblemen en bijbehorende maatregelen}

Vanwege de aansluitingsproblemen tussen de vraag en het aanbod van technisch personeel is het lang niet altijd eenvoudig om voldoende geschikt personeel aan te trekken. Figuur 3.Io laat zien in welke mate metalektrobedrijven in de afgelopen vijf jaar problemen ondervonden bij het aantrekken van technische medewerkers. Er is een duidelijk verschil zichtbaar tussen de wervingsproblemen tot en met 2008 en de periode hierna. In 2007 en 2008 rapporteerde bijna de helft van de bedrijven veel problemen bij het vinden van geschikte technici. In 2009 kelderde dit percentage als gevolg van de economische crisis en had nog slechts minder dan IO\% van de bedrijven veel wervingsproblemen. Ruim de helft van de bedrijven had op dat moment geen of nauwelijks problemen om voldoende technici aan te trekken. In 2010 en 201 neemt het percentage bedrijven dat veel wervingsproblemen heeft door de krapper wordende arbeidsmarkt weer toe. Hoewel het niveau van de wervingsproblematiek van voor de crisis nog lang niet bereikt werd, gaf in $201 \mathrm{I}$ een kwart weer aan met veel of zelfs erg veel problemen te kampen bij het aantrekken van technici. Daar staat tegenover dat in $201 \mathrm{I}$ een derde van de bedrijven geen of nauwelijks wervingsproblemen ondervond. In 2009 was dat echter nog bij meer dan de helft (54\%) van de bedrijven het geval.

\section{Figuur 3.10}

Percentage bedrijven naar problemen bij het vinden van technisch personeel, 2007-2011

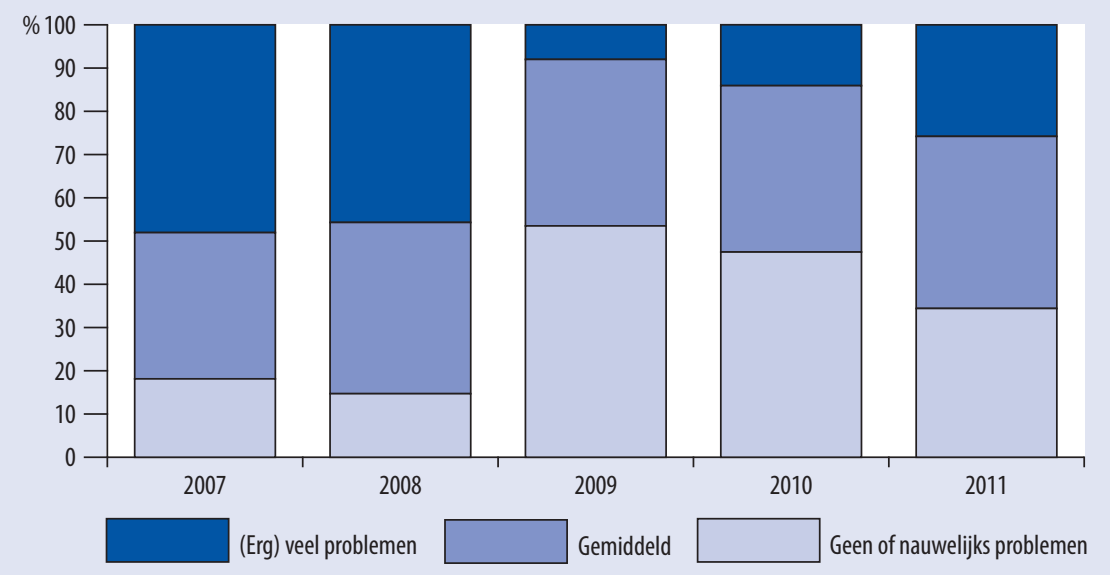

Bron: ROA, Arbeidsmarktmonitor Metalektro, 2007-2011

De wervingsproblematiek kan daarbij behoorlijk verschillen afhankelijk van de functiecategorie die het betreft. Uit figuur 3.Ir blijkt dat de bedrijven in alle jaren de meeste problemen hebben bij het aantrekken van nieuwe medewerkers voor de uitvoerende technische functies. Hoewel de conjunctuur ook hier een belangrijke rol speelt, is het opmerkelijk dat de wervingsproblematiek bij het aantrekken van uitvoerende technici continu op een hoog niveau ligt. Over alle jaren heen geeft gemiddeld 7 op de Io 
bedrijven in de Metalektro aan dat zij problemen ondervinden bij het zoeken naar geschikte uitvoerende technici. In $201 \mathrm{I}$ was dit niet anders. Functies voor technisch opgeleide verkopers worden daarentegen veel gemakkelijker ingevuld. Minder dan $20 \%$ van de bedrijven geeft aan problemen te ondervinden bij de werving voor deze functies. Bij de leidinggevende en ondersteunende technische functies ligt het aantal bedrijven dat wervingsproblemen ondervindt op een iets hoger niveau. Daarbij is het opmerkelijk dat het aantal bedrijven dat problemen ondervindt bij de werving van ondersteunende technici na 2008 sterk is teruggelopen, terwijl er bij de leidinggevende technici een lichte toename is van het aantal bedrijven met wervingsproblemen.

\section{Figuur 3.11}

Percentage bedrijven met problemen bij het vinden van technisch personeel, naar beroepscategorie van de werknemer, 2007-2011

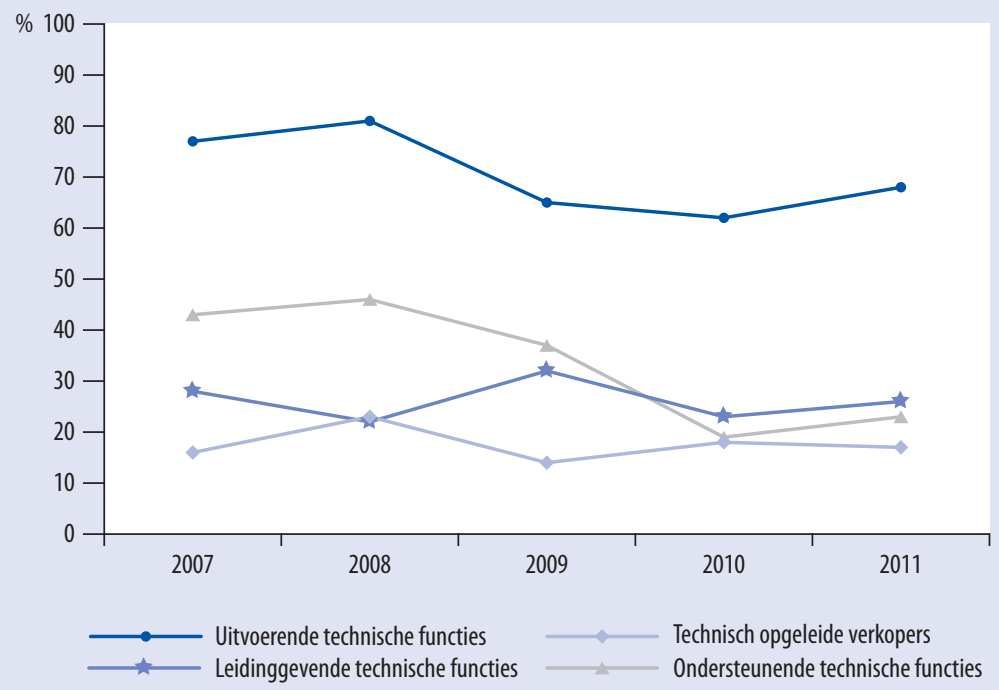

Bron: ROA, Arbeidsmarktmonitor Metalektro, 2007-2011

Er zijn in 20 II nog enkele opvallende regionale verschillen zichtbaar. Zo blijkt uit figuur 3.12 dat bedrijven in de regio Zuid minder vaak problemen ervaren bij de werving van uitvoerend technisch personeel. In deze regio geeft weliswaar de helft aan dat zij in $201 \mathrm{I}$ met problemen kampten bij het invullen van hun vacatures voor deze functies, maar in de regio's West en Noord/Oost geldt dit voor veel meer bedrijven (respectievelijk $75 \%$ en $79 \%$ van alle bedrijven in deze regio's). In het Zuiden worden daarentegen veel vaker problemen ondervonden bij de werving van technisch opgeleide verkopers. In het Westen van het land spitst de problematiek zich juist meer toe op de werving van leidinggevend technisch personeel. Deze regio kent daarentegen relatief minder problemen bij het aantrekken van ondersteunend technisch personeel. 
Figuur 3.12

Regionale verdeling percentage bedrijven met problemen bij het vinden van technisch personeel, naar beroepscategorie van de werknemer, 2011

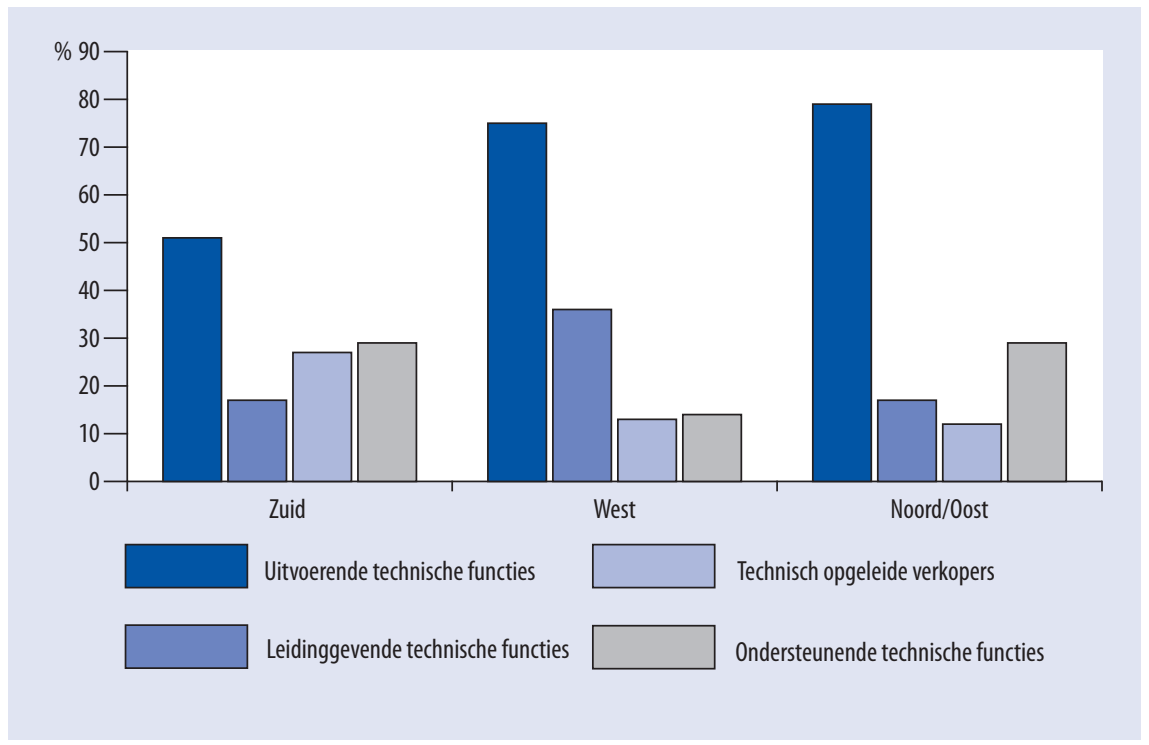

Bron: ROA, Arbeidsmarktmonitor Metalektro, 2011

Aan de wervingsproblemen die bedrijven ervaren als zij op zoek zijn naar technisch personeel kunnen uiteenlopende redenen ten grondslag liggen. Deze kunnen variëren van te weinig aanbod van technisch opgeleiden in het algemeen tot sollicitanten die in de ogen van de bedrijven onrealistische salariseisen hebben waardoor er geen match plaats kan vinden tussen vraag en aanbod. In figuur 3.13 worden de meest genoemde problemen die de bedrijven in 201 ondervonden weergegeven. Daarbij vindt bovendien een vergelijking met 20 Io plaats om te achterhalen of er zich op dit punt recentelijk belangrijke veranderingen hebben voorgedaan.

Evenals in voorgaande jaren gaven bedrijven in $201 \mathrm{I}$ te kennen dat er vooral vaak nog het een en ander schort aan de competenties waarover sollicitanten beschikken. Er is weliswaar sprake van een lichte afname van het percentage bedrijven dat dit aangeeft ten opzichte van 20I0, maar in 201 geeft nog altijd $57 \%$ van de bedrijven aan dat dit een probleem is dat het invullen van hun vacatures bemoeilijkt. Ongeveer de helft van de bedrijven geeft daarnaast aan dat er te weinig aanbod van sollicitanten is. Dit is een opmerkelijk toename ten opzichte van 2009 en 2010 , toen minder dan $30 \%$ van de bedrijven dit een probleem vond. In 20 II wordt het gebrek aan sollicitanten voor het eerst weer zo net vaak als probleem genoemd als voor de crisis. Aangenomen mag worden dat dit de komende jaren alleen nog maar zal toenemen doordat de generatie babyboomers die met pensioen gaat vervangen moet worden, waarvoor de arbeidsmarktinstroom van schoolverlaters niet toereikend zal zijn (zie hoofdstuk 7). 


\section{Figuur 3.13}

Percentage bedrijven met belangrijkste problemen bij het vinden van technisch personeel, 20102011

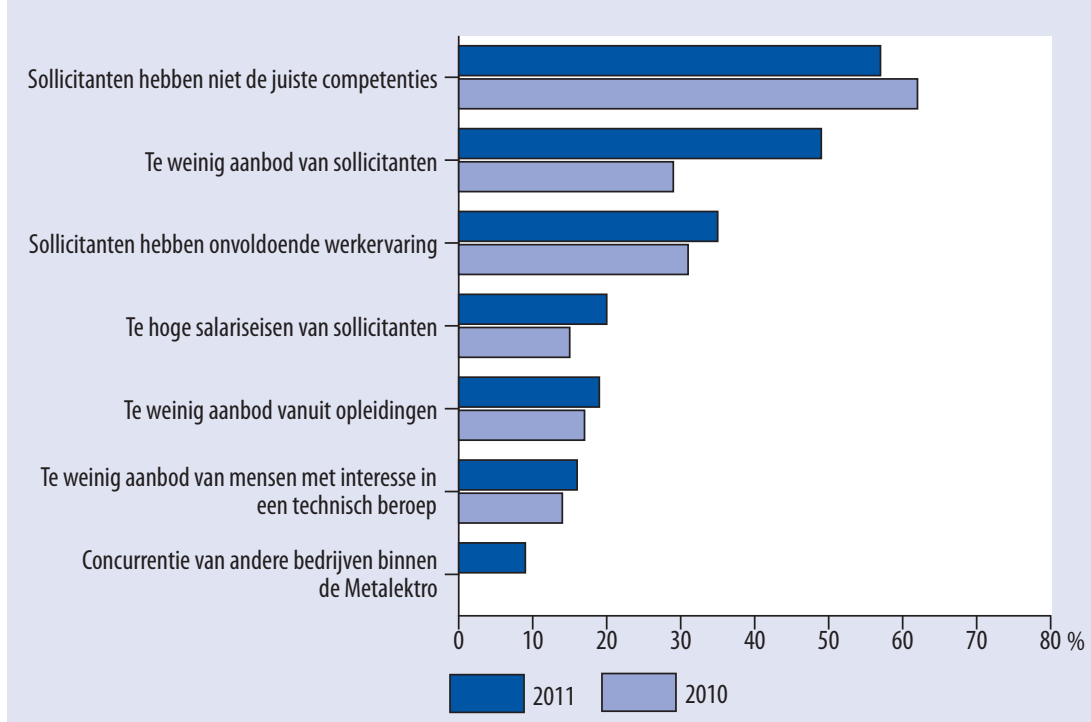

Noot: 'Te hoge andere eisen van sollicitanten (deeltijd, flexibel werken)' en 'concurrentie van andere bedrijven buiten de Metalektro' zijn eveneens als antwoordcategorie opgenomen, maar worden door minder dan $5 \%$ van de bedrijven genoemd.

Bron: ROA, Arbeidsmarktmonitor Metalektro, 2010-2011

Een ander veelgenoemd probleem bij de werving van technici is volgens de bedrijven dat sollicitanten onvoldoende werkervaring hebben. Dit probleem zouden bedrijven gedeeltelijk kunnen ondervangen door deze sollicitanten intern te laten begeleiden door meer ervaren medewerkers die hen het vak bijbrengen. Het risico is echter dat deze nieuwe medewerkers op de korte termijn onvoldoende productief ingezet kunnen worden. Opvallend is dat, met uitzondering van het gebrek aan de juiste competenties, alle wervingsprobleem in $201 \mathrm{I}$ vaker genoemd worden dan in 2010.

Wanneer bedrijven hier niet tijdig op anticiperen, zullen zij op kortere of langere termijn niet ontkomen aan de negatieve gevolgen van de tekorten aan technisch personeel (zie ook hoofdstuk 7). Dit roept de vraag op met welke direct merkbare problemen deze berdrijven dan geconfronteerd zullen worden. Om deze vraag te kunnen beantwoorden wordt hier ingezoomd op de gevolgen die bedrijven nu al ondervinden door de schaarste aan technisch personeel. Dit kan andere bedrijven helpen om mogelijke toekomstige problemen tijdig inzichtelijk te maken en - zo mogelijk - trachten te voorkomen. 
Figuur 3.I4 geeft de recente ontwikkeling weer van de vijf meest genoemde direct merkbare gevolgen van de tekorten aan technici. In de afgelopen jaren is bij tekorten aan technisch personeel vooral de werkdruk toegenomen. Tijdens de crisis in 2009 was er tijdelijk minder werk en nam ook de werkdruk af, maar sindsdien is deze weer fors gestegen. Aangezien veel bedrijven in eerste instantie terughoudend zijn om weer nieuw personeel aan te nemen, zorgt dit ervoor dat het werk door minder mensen gedaan moet worden. Het overgrote deel van de bedrijven die in 2011 met een tekort aan technisch personeel kampte noemt de toegenomen werkdruk als een direct merkbaar gevolg. Dit punt verdient zeker aandacht. Op de langere termijn kan een te hoge werkdruk het verzuim in een bedrijf omhoog stuwen. Voor de werknemers zelf kan een te hoge werkdruk op den duur ook negatieve gevolgen hebben in de vorm van mentale problemen of soms zelfs een burn-out.

\section{Figuur 3.14}

Ontwikkeling vaakst genoemde direct merkbare gevolgen van tekorten aan technisch personeel, 2008-2011

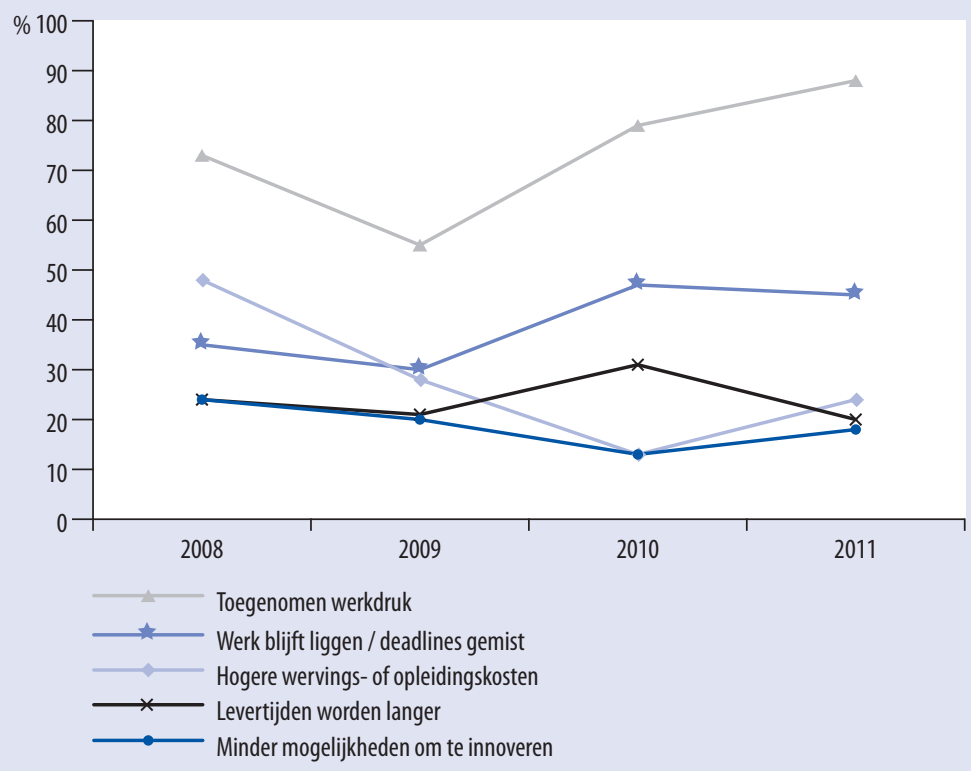

Bron: ROA, Arbeidsmarktmonitor Metalektro, 2008-2011

Sinds de krimp van de personeelsomvang in veel bedrijven in 2009, wordt vaker aangegeven dat er werk blijft liggen en deadlines worden gemist. Ook gaf in dat jaar bijna 3 op de Io bedrijven aan dat zij meer aan wervings- of opleidingskosten zijn gaan uitgeven om het personeelsbestand kwantitatief en kwalitatief op peil te houden. In 20IO was dat bij veel minder bedrijven het geval, maar in 20II neemt dit voor het eerst na de crisis weer toe. Een kwart van de bedrijven merkte de afgelopen jaren dat hun levertijden opliepen bij een tekort aan technisch personeel. In 20 II is dit echter 
behoorlijk afgenomen ten opzichte van het jaar daarvoor. Een ander gevolg van deze tekorten is dat er minder mogelijkheden zijn om te innoveren. Recentelijk is dit voor gemiddeld een vijfde van de bedrijven een direct merkbaar gevolg van de personeelstekorten. In $201 \mathrm{~s}$ stijgt het percentage bedrijven dat vanwege personeelstekorten minder mogelijkheden ziet om te innoveren weer enigszins.

\section{Maatregelen}

Bedrijven die te kampen hebben met personeelstekorten en daardoor problemen ondervinden bij de werving van nieuwe medewerkers zullen hun wervingsbeleid normaal gesproken aanpassen om meer succes te kunnen boeken bij het invullen van de moeilijk vervulbare vacatures. Figuur 3.15 laat zien in hoeverre bedrijven hun wervings- en selectiebeleid aanpassen om moeilijk vervulbare vacatures voor technisch personeel toch ingevuld te krijgen. Daarbij wordt ook aangegeven hoe effectief deze aanpassingen volgens de bedrijven zijn. Bedrijven konden bij elke aanpassing aangeven dat zij deze (I) niet hebben toegepast, (2) wel hebben toegepast maar weinig baat ervan hadden, (3) wel hebben toegepast en het effect ervan merkten, of (4) wel hebben toegepast en merkten dat het zeer effectief was.

In de figuur geeft de horizontale as aan hoeveel procent van de bedrijven hun wervingsen selectiebeleid op een bepaald punt aanpassen, terwijl de verticale as aangeeft of een aanpassing effectief of zelfs zeer effectief is (antwoordcategorie 3 en 4 ). Verwacht mag worden dat de aanpassingen die het meest effectief zijn ook het meest toegepast worden. Dit zijn de aanpassingen die rechtsboven in de figuur staan. De minst effectieve aanpassingen die ook weinig toegepast worden staan daarentegen helemaal linksonder in de figuur.

De figuur laat zien dat nagenoeg alle bedrijven die met moeilijk vervulbare vacatures kampen de expertise van uitzendbureaus, commerciële werving- en selectiebureaus of detacheringsbureaus inschakelen (punt I). Van deze groep vindt 8 op de Io bedrijven dit een effectief of zelfs zeer effectief middel om moeilijk vervulbare vacatures ingevuld te krijgen. Bijna $80 \%$ van de bedrijven probeert moeilijk vervulbare vacatures ingevuld te krijgen door goede loopbaanperspectieven te bieden (punt 2) en mensen met minder ervaring aan te trekken punt (3). In beide gevallen vindt iets meer dan de helft van de bedrijven dat dit (zeer) effectief is. Er zijn nog twee andere aanpassingen in het wervings- en selectiebeleid die door meer dan de helft van de bedrijven toegepast worden. Zo worden scholieren door $70 \%$ van de bedrijven actiever benaderd (punt 4), terwijl $40 \%$ van de bedrijven dit een (zeer) effectief middel vindt om vacatures ingevuld te krijgen. Ook wordt bij bijna $60 \%$ van de bedrijven een wervingsbonus uitgekeerd aan het personeel als zij een geschikte nieuwe medewerker aandragen (punt 5). Echter, minder dan een kwart van de bedrijven vindt dit een effectief middel. 


\section{Figuur 3.15}

Percentage bedrijven naar aanpassingen in werving en selectie om met moeilijk vervulbare vacatures voor technisch personeel om te gaan, 2011

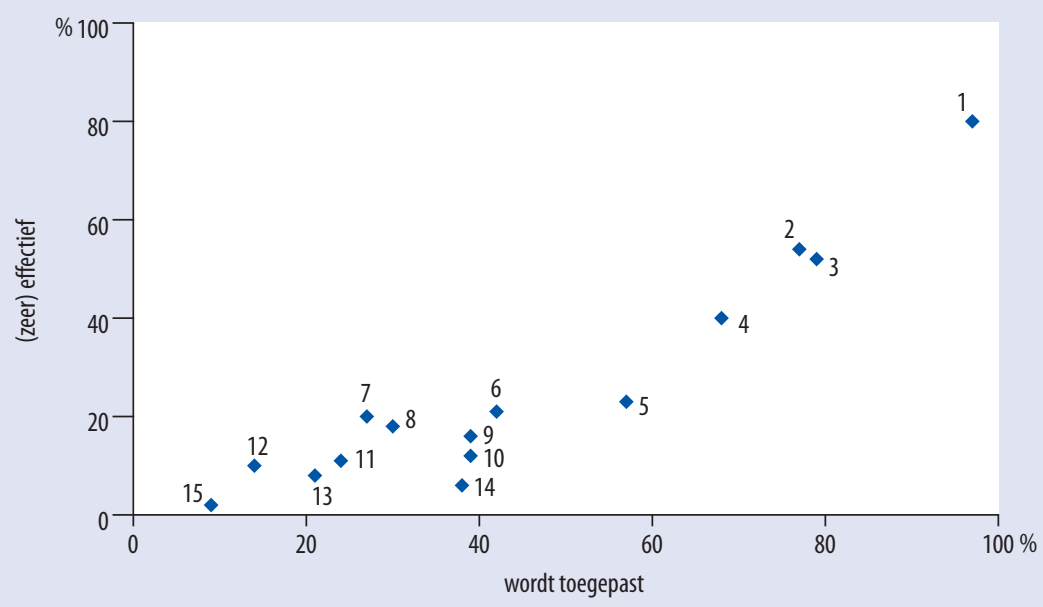

1. Inschakelen uitzend-, commerciële werving- en selectie- of detacheringsbureaus;

2. Bieden goede loopbaanperspectieven;

3. Aantrekken minder ervaren personeel;

4. Scholieren actiever benaderen;

5. Wervingsbonus voor eigen personeel;

6. Competentiegericht werven;

7. Werven in het buitenland;

8. Collegiaal inlenen van personeel;

9. Aantrekken opgeleiden uit andere richting;

10. Aantrekken van lager opgeleiden;

11. Bieden van hoger salaris;

12. Inschakelen bureau voor arbeidsmarktcommunicatie;

13. Bieden van CAO-overstijgende arbeidsvoorwaarden;

14. Inschakelen UWV WERKbedrijf (voormalig: (WI);

15. Actiever benaderen van gedeeltelijk arbeidsongeschikten.

Bron: ROA, Arbeidsmarktmonitor Metalektro, 2011

De overige aanpassingen worden door minder bedrijven toegepast en zijn vaak ook minder effectief. De minst effectieve aanpassingen blijken het actiever benaderen van gedeeltelijk arbeidsongeschikten (punt 15), het inschakelen van het UWV WERKbedrijf (punt I4) en het bieden van betere CAO-overstijgende arbeidsvoorwaarden (punt 13). Mogelijke aanpassingen in het wervings- en selectiebeleid die bedrijven naar eigen zeggen nauwelijks toepassen zijn het actiever benaderen van gedeeltelijk arbeidsongeschikten (punt I5) en het inschakelen van een bureau voor arbeidsmarktcommunicatie (punt I2).

Naast aanpassingen in het werving- en selectiebeleid kan een bedrijf er ook voor kiezen om de interne organisatie aan te passen. Figuur 3.16 laat zien welk deel van de bedrijven overgaat tot acht mogelijke aanpassingen. Evenals in figuur 3.15 worden deze 
gerelateerd aan de effectiviteit die deze aanpassingen volgens de bedrijven zelf hebben. De meest toepaste en tegelijkertijd meest effectieve aanpassing in de interne organisatie bestaat uit het flexibel inzetten van de eigen medewerkers. Dit wordt door ruim 9 van de Io toegepast, waarvan driekwart dit een (zeer) effectieve aanpassing vindt. Ook laten veel bedrijven hun personeel als gevolg van moeilijk vervulbare vacatures veel overwerken en wordt het personeel om- of bijgeschoold voor de vacante functies. Dit wordt door $70 \%$ van de bedrijven als (zeer) effectief ervaren. De andere aanpassingen van de interne organisatie die relatief vaak worden ingezet en redelijk effectief blijken te zijn, zijn het uitbesteden van werk binnen Nederland en het aanpassen van de organisatie van het werk.

\section{Figuur 3.16}

Percentage bedrijven naar interne aanpassingen om met moeilijk vervulbare vacatures voor technisch personeel om te gaan, 2011

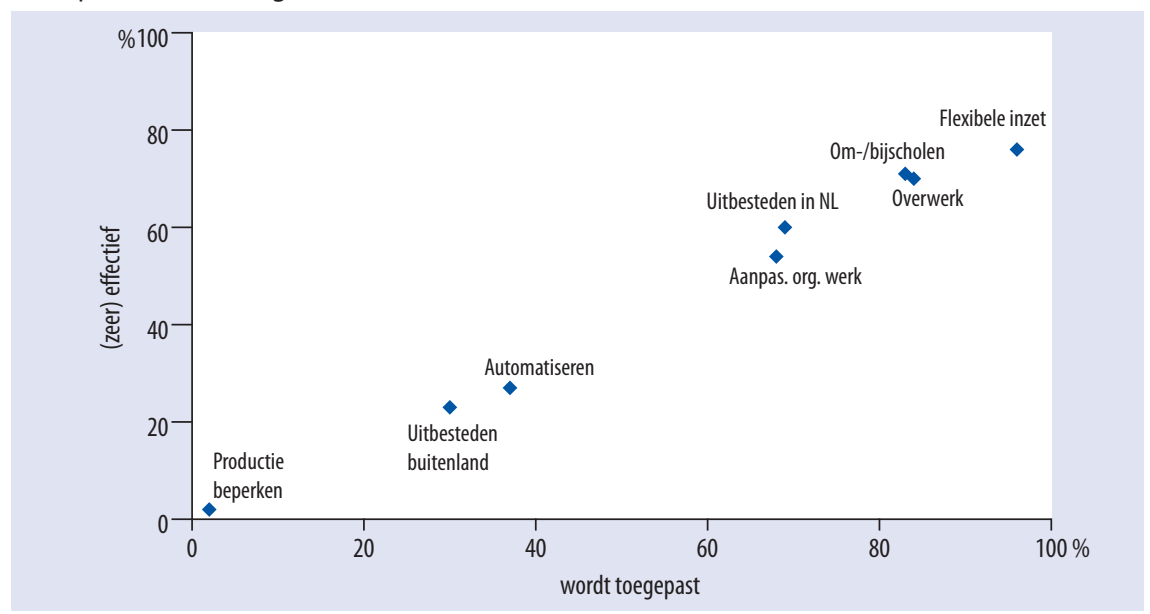

Bron: ROA, Arbeidsmarktmonitor Metalektro, 2011

Het beperken van de productie is duidelijk de maatregel waartoe bedrijven als allerlaatste toe overgaan. Eigenlijk werpt men dan de handdoek in de ring. Slechts $2 \%$ van de bedrijven was hiertoe in $201 \mathrm{I}$ genoodzaakt. Bedrijven kiezen dan nog vaker voor automatisering of het uitbesteden van werk aan bedrijven die gevestigd zijn in het buitenland. Circa een derde van de bedrijven probeerde op deze manier de problemen die ze ondervonden door moeilijk vervulbare vacatures op te vangen. Een kwart van de bedrijven vond dit (zeer) effectief. 



\section{Competenties en opleidingsinspanningen}

Vanwege de elkaar snel opvolgende veranderingen in de meeste technische functies, moet er in de Metalektro continu gë̈nvesteerd worden in het competentieniveau van het personeel. In de toekomst zullen gedragsmatige competenties steeds belangrijker worden. De trainingsdeelname is in 201 I echter over de gehele linie afgenomen, zowel bij medewerkers met een vast, tijdelijk als flexibel dienstverband. Gemiddeld besteden metalektrobedrijven in 2011 I.800 euro per getrainde werknemer.

Bedrijven bieden hun technisch personeel in $20 I I$ voornamelijk de mogelijkheid om hun vaktechnische vaardigheden verder te ontwikkelen. In vergelijking met $20 I$ zal er volgens de bedrijven in 20I2, naast de vaktechnische vaardigheden, vooral meer aandacht besteed worden aan veiligheid en communicatieve vaardigheden.

De interne mobiliteit in de Metalektro is vrij laag. Een hogere interne mobiliteit zou zowel de duurzame inzetbaarheid van het personeel als de aantrekkingskracht die de sector op de arbeidsmarkt heeft kunnen verbeteren. Dit vereist een goed loopbaanmanagement. Wat dat betreft is het een gunstige ontwikkeling dat metalektrobedrijven, na een flinke daling in 20I0, in 2011 weer iets vaker functionerings- en beoordelingsgesprekken inzetten voor het loopbaanmanagement van hun technisch personeel. Daarentegen lijkt het in de afgelopen jaren toegenomen gebruik van persoonlijke ontwikkelingsplannen (POP's) weer over zijn hoogtepunt heen te zijn. 


\subsection{Huidig en gewenst competentieniveau}

De aanhoudende stroom technologische en sociale innovaties vergt van het personeel dat zij meegaan met het tempo van deze ontwikkelingen. Dit is alleen mogelijk als werknemers hun competenties continu blijven ontwikkelen. Ook de verwachte toekomstige tekorten aan kennis en vaardigheden die de komende jaren kunnen ontstaan door de uitstroom van technisch personeel als gevolg van de vergrijzing in de sector, maken het noodzakelijk dat de competenties van het personeel continu op peil gehouden moeten worden. In succesvolle bedrijven staat het begrip Leven Lang Leren dan ook hoog op de agenda. Zij zijn doordrongen van het feit dat goed geschoolde medewerkers productiever werken waardoor bedrijven op hun beurt weer kunnen profiteren van de ontwikkeling van hun medewerkers. Veel medewerkers waarderen het bovendien als zij de mogelijkheid krijgen om zich te blijven ontwikkelen, omdat dit hun eigen werkzekerheid en loopbaanmogelijkheden vergroot. Zo snijdt het mes aan twee kanten.

Om hun medewerkers optimaal productief inzetbaar te houden, is het van belang dat bedrijven tijdig anticiperen op de verwachte toekomstige veranderingen binnen functies. Zij moeten hierop inspelen door er voor te zorgen dat het personeel tijdig over de vereiste competenties beschikt. Wanneer bijvoorbeeld nu al bekend is dat er over twee jaar bepaalde kennistekorten zullen ontstaan door de uitstroom van oudere medewerkers met specifieke ervaring, kan nu reeds begonnen worden met de kennisoverdracht van oudere op jongere medewerkers. In figuur 4.I is te zien welke veranderingen binnen de technische functies er door de bedrijven verwacht worden. Hierbij wordt een onderscheid gemaakt tussen competenties die in toenemende mate gevraagd zullen worden op de korte termijn (2OI2) en de middellange termijn (20I32016).

Evenals in 2010 is de meest genoemde verwachte verandering in de technische functies dat het belang van gedragsmatige competenties de komende vijf jaar zal toenemen. Zowel in 2010 als in $201 \mathrm{I}$ verwachten twee van de drie bedrijven dat deze competenties nog belangrijker zullen worden. In tegenstelling tot 2010 is ditmaal echter de verwachting dat deze verwachte trend zich vooral op de middellange termijn zal doorzetten. Verwachtte in 2010 nog $5 \mathrm{I} \%$ dat gedragsmatige competenties op de korte termijn belangrijker zouden worden, in $20 \mathrm{II}$ is dit afgenomen tot $38 \%$. De verwachte ontwikkeling voor de middellange termijn laat daarentegen het omgekeerde beeld zien en wordt in 201 juist vaker genoemd. Verwachtte in 2010 nog $17 \%$ van de bedrijven dat het belang van gedragsmatige competenties op de middellange termijn zou toenemen; in $201 \mathrm{II}$ is dit gestegen tot $29 \%$. De toekomst moet uitwijzen of er in dit geval gewoon sprake is van uitstel, of dat de meest urgente problemen op dit punt al zijn verminderd. Ook bij de meeste andere verwachte veranderingen vindt er in $20 \mathrm{II}$ een verschuiving plaats van de korte naar de middellange termijn. 
Verder verwacht ruim de helft van de bedrijven dat er in de toekomst meer verantwoordelijkheden in de technische functies op een lager niveau binnen de organisatie komen te liggen en dat technische functies ook meer allround zullen worden. Naast de grote groep bedrijven die verwacht dat technische functies meer allround worden, zijn er echter ook nogal wat bedrijven die aangeven dat technische functies in hun bedrijf de komende jaren juist specialistischer van aard zullen worden. Een derde verwacht namelijk meer functiespecialisatie binnen nu en vijf jaar. Ook interessant om te zien is dat meer dan $40 \%$ van de bedrijven verwacht dat er zich de komende vijf jaar geen wezenlijke veranderingen binnen de technische functies zullen voordoen en voorziet een status quo. Dit roept de vraag op of in deze bedrijven de verwachte dynamiek minder hectisch is dan in andere bedrijven, of dat deze bedrijven de veranderingsprocessen onderschatten.

Figuur 4.1

Verwachte veranderingen in de technische functies in 2012 en 2013-2016

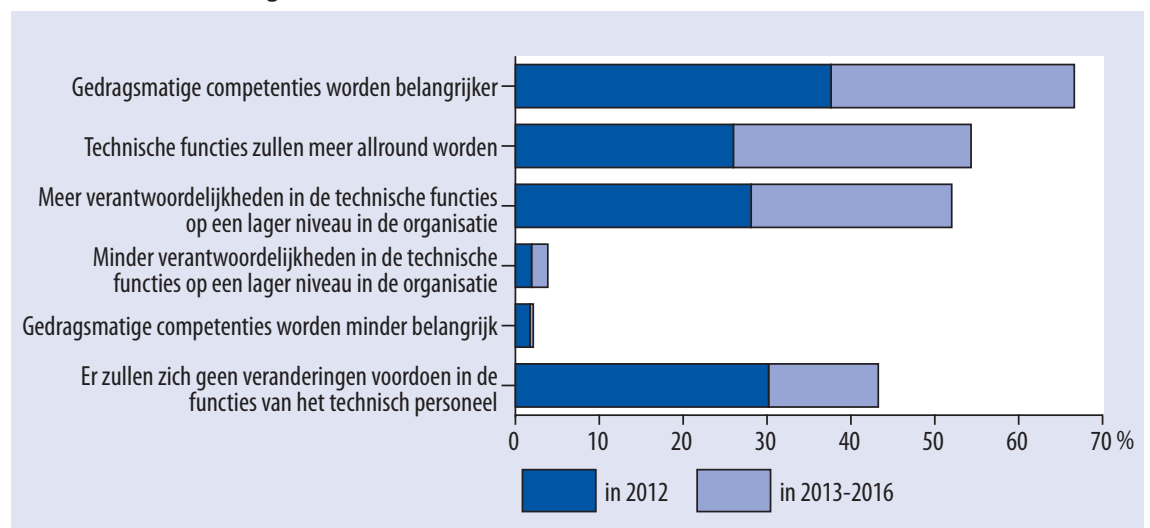

Bron: ROA, Arbeidsmarktmonitor Metalektro, 2011

\subsection{Scholing en competentieontwikkeling}

Nadat bedrijven zich een beeld hebben gevormd van de veranderingen die er naar alle waarschijnlijkheid zullen optreden in de technische functies in hun bedrijf, kunnen zij vaststellen of het nodig is om hun medewerkers op deze specifieke competenties bij te scholen. Technische medewerkers met competentietekorten worden zo in staat gesteld om cursussen of trainingen te volgen die hen helpen om hun huidige functie of een andere functie binnen het bedrijf in de toekomst optimaal te kunnen uitoefenen. Vaak wordt in goed onderling overleg tussen de leidinggevende en de werknemer afgesproken om de werknemer een cursus of training te laten volgen. Dit gebeurt in meer dan 40\% van de bedrijven. Daarnaast ligt het initiatief tot cursusdeelname vaak bij de direct leidinggevende (35\%). In mindere mate wordt vanuit de HRM-afdeling geïnitieerd dat medewerkers een bepaalde training moeten volgen (I6\%). Technische 
werknemers zelf blijken slechts bij 7\% van de bedrijven zelf het initiatief te nemen door te vragen of ze een cursus mogen volgen. Dit kan er op wijzen dat werknemers op dit punt te weinig assertief of proactief zijn, maar het is ook mogelijk dat werknemers minder goed kunnen inschatten welke veranderingen er de komende jaren in hun werk zullen optreden dan het bedrijf zelf.

De scholing die medewerkers volgen is vooral gericht op hun huidige functie. Bijna driekwart van de cursussen is hierop gericht. Daarnaast worden er voornamelijk opleidingen gevolgd die gericht zijn op de verdere carrière van de werknemer binnen het bedrijf (25\%). In lijn met de verwachting is slechts een marginaal deel van de cursussen bedoeld voor de ontwikkeling van werknemers met het oog op een loopbaan buiten het bedrijf ( $3 \%)$. Bedrijven zullen immers primair investeren in competenties waar zij zelf de vruchten van kunnen plukken. Daar staat echter tegenover dat zowel werknemers als het bedrijf zelf er baat bij kan hebben als medewerkers die niet tot hun pensioen bij het bedrijf kunnen werken vroeg genoeg worden om- of bijgeschoold om hen voor andere bedrijven aantrekkelijk te maken.

\section{Dienstverband}

Het is algemeen bekend dat er doorgaans meer geïnvesteerd wordt in medewerkers met een vast dienstverband dan in medewerkers met een contract voor bepaalde tijd of uitzend- en oproepkrachten. Dit wordt veroorzaakt doordat bedrijven willen profiteren van hun investeringen in menselijk kapitaal. Wanneer bedrijven meer zekerheid hebben dat zij kunnen profiteren van deze investeringen dan zullen zij ook eerder geneigd zijn om hierin te investeren. Dit verband blijkt duidelijk uit figuur 4.2. Deze figuur geeft voor de verschillende soorten dienstverbanden weer welk deel van de technische medewerkers met een dergelijke contractvorm in $201 \mathrm{I}$ ten minste één cursus of training heeft gevolgd. In 201 i volgde iets minder dan de helft van het technisch personeel in vaste dienst een cursus. Bij de tijdelijke arbeidskrachten was dit een veel kleiner deel: slechts I op de 5 volgde scholing, terwijl bij de technische medewerkers die geen dienstverband bij het bedrijf zelf hadden (gedetacheerden, uitzend- en oproepkrachten) in 20 II slechts I op de 20 aan een cursus of training heeft deelgenomen.

In de figuur wordt ook een vergelijking met 20 Io gemaakt. Hieruit blijkt dat de trainingsdeelname van technische medewerkers in $20 \mathrm{II}$ is afgenomen ten opzichte van die in 20IO. Dit geldt zowel voor medewerkers met een vast contract als voor degenen met een tijdelijk contract en medewerkers zonder dienstverband (gedetacheerden, uitzendkrachten, etc.). Daarbij vond de sterkste daling van de trainingsdeelname plaats onder de medewerkers in vaste dienst. Dit heeft er wellicht mee te maken dat er in mindere mate bezuinigd kon worden op cursussen die gevolgd moeten worden door personen met een tijdelijk contract of uitzendkrachten en gedetacheerden. Zij volgen immers vooral trainingen en cursussen die noodzakelijk zijn om de functie uit te kunnen oefenen. Bij medewerkers in vaste dienst gaat het bovendien vaker om 
iets langer durende en duurdere cursussen die soms wel enige tijd uitgesteld kunnen worden als er bezuinigd moet worden. Daarbij speelt dat het niveau van de cursusdeelname in 2010 sowieso al erg hoog was doordat nogal wat bedrijven hun boventallige medewerkers die gebruik maakten van deeltijd-WW bijschoolden.

\section{Figuur 4.2}

Percentage van het technisch personeel dat minimaal één cursus of training heeft gevolgd naar dienstverband, 2010-2011

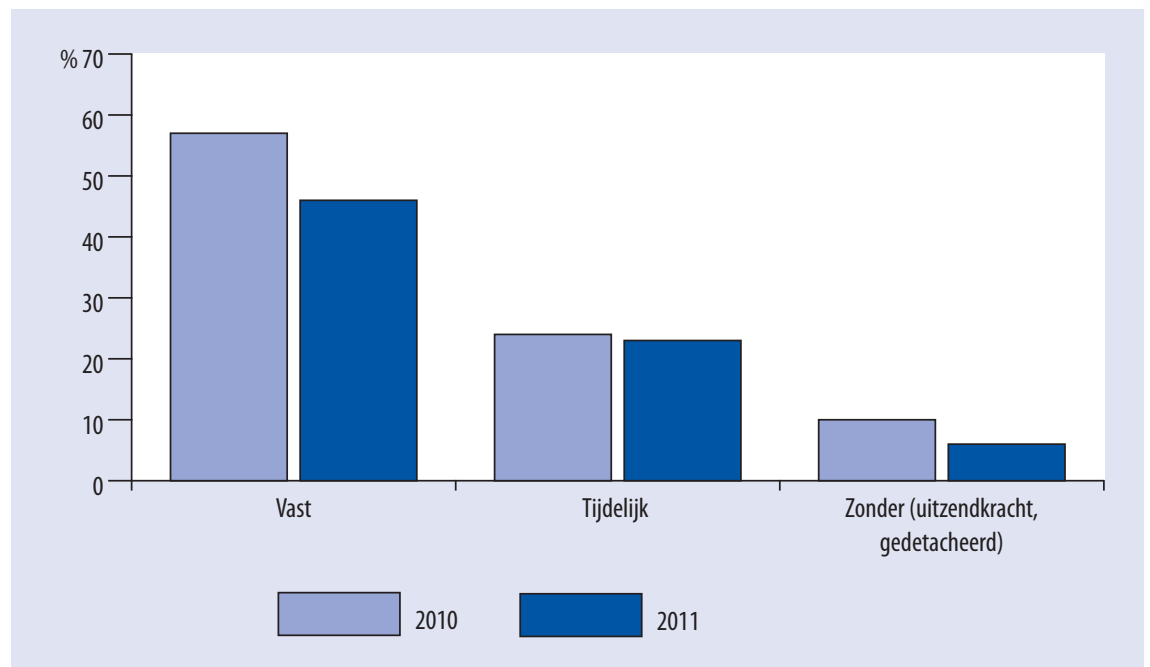

Bron: ROA, Arbeidsmarktmonitor Metalektro, 2010-2011

Bij de trainingsdeelname onder het technisch personeel zijn er bovendien enkele opvallende regionale verschillen (figuur 4.3). In de regio Noord/Oost ligt de scholingsdeelname lager dan in de andere regio's. Van de technische medewerkers met een vast dienstverband in deze regio volgde in 20 II slechts I op de 3 een cursus of training, terwijl dit landelijk gezien bijna de helft was. Bij medewerkers met een tijdelijk contract blijft de regio Noord/Oost eveneens achter bij het landelijk gemiddelde. In die regio volgde in 2011 II\% minimaal één cursus, wat nog niet de helft is van het landelijke gemiddelde van bijna een kwart. Bedrijven in het Westen van het land scoren daarentegen bovengemiddeld wat betreft de trainingsdeelname van medewerkers met een tijdelijk dienstverband en personeel zonder dienstverband. Zoals gezegd, daalde de trainingsdeelname tussen 2010 en 201 het hardst onder vaste medewerkers. Daarbij ging het in de regio's West en Noord/Oost zelf om een daling met zo'n I8\%-punt. 


\section{Figuur 4.3}

Scholingsdeelname technisch personeel naar dienstverband en regio, 2011

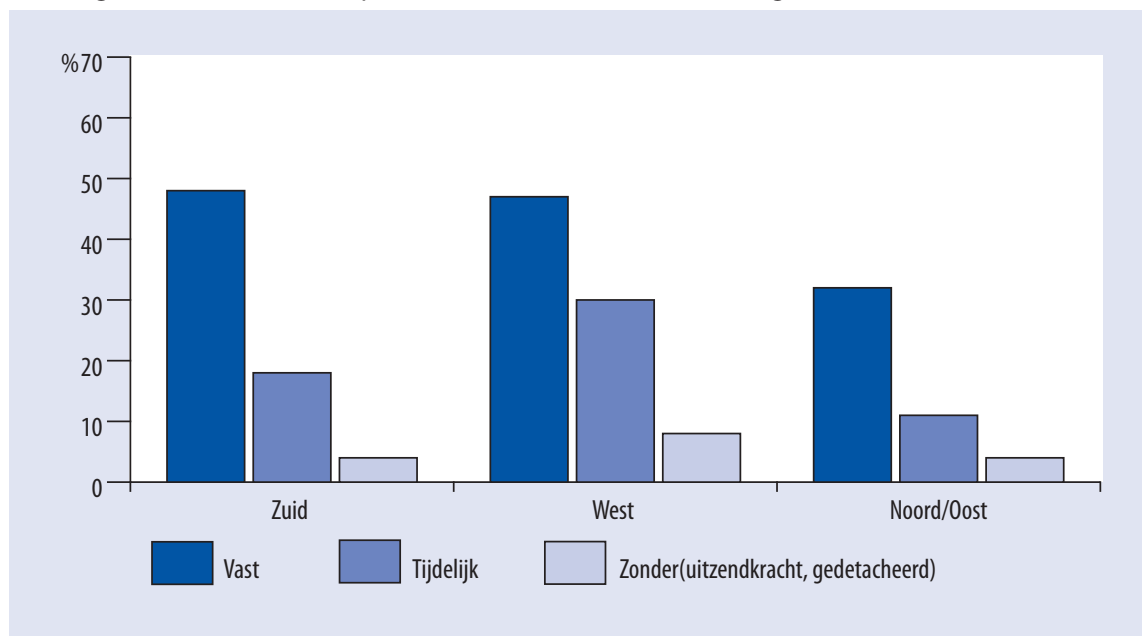

Bron: ROA, Arbeidsmarktmonitor Metalektro, 2011

Metalektrobedrijven besteden in 20 II gemiddeld I.80o euro (out-of-pocket) per getrainde medewerker. Deze directe kosten voor cursussen en trainingen zijn het hoogst bij de bedrijven in de sectoren metaalproducten en machinebouw. In totaal besteden metalektrobedrijven gemiddeld $\mathrm{I}, 5 \%$ van de loonsom an out-of-pocket kosten aan scholing. Dit is duidelijk minder dan in de afgelopen jaren (figuur 4.4).

\section{Figuur 4.4}

Ontwikkeling gemiddelde totale opleidingskosten per bedrijf als percentage van de loonsom, 2004-2011

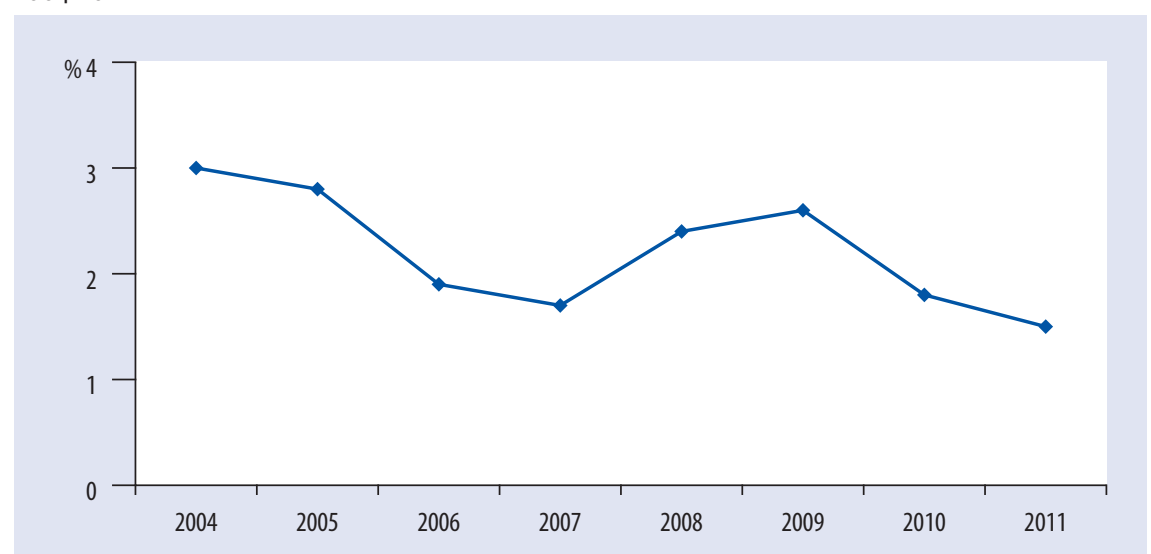

Bron: ROA, Arbeidsmarktmonitor Metalektro, 2004-2011 
Aan de bedrijven in de Metalektro is eveneens gevraagd welke cursussen en trainingen hun technisch personeel zoal volgt. Figuur 4.5 laat zien welke opleidingen het technisch personeel in $201 \mathrm{I}$ gevolgd heeft. Daarnaast wordt in de figuur weergegeven welke scholing het technisch personeel naar verwachting in 2012 zal gaan volgen. Deze verwachtingen worden weergegeven aan de hand van ruitjes. Als de ruitjes boven de staaf uitkomen wordt dus een hogere deelname aan de desbetreffende scholing verwacht, terwijl een ruitje onder de top van een staaf betekent dat deze opleidingen in 2012 naar verwachting minder belangrijk zullen zijn dan in $20 I I$.

\section{Figuur 4.5}

In 2011 gevolgde trainingen en cursussen en in 2012 verwachte trainingen en cursussen (\% bedrijven)

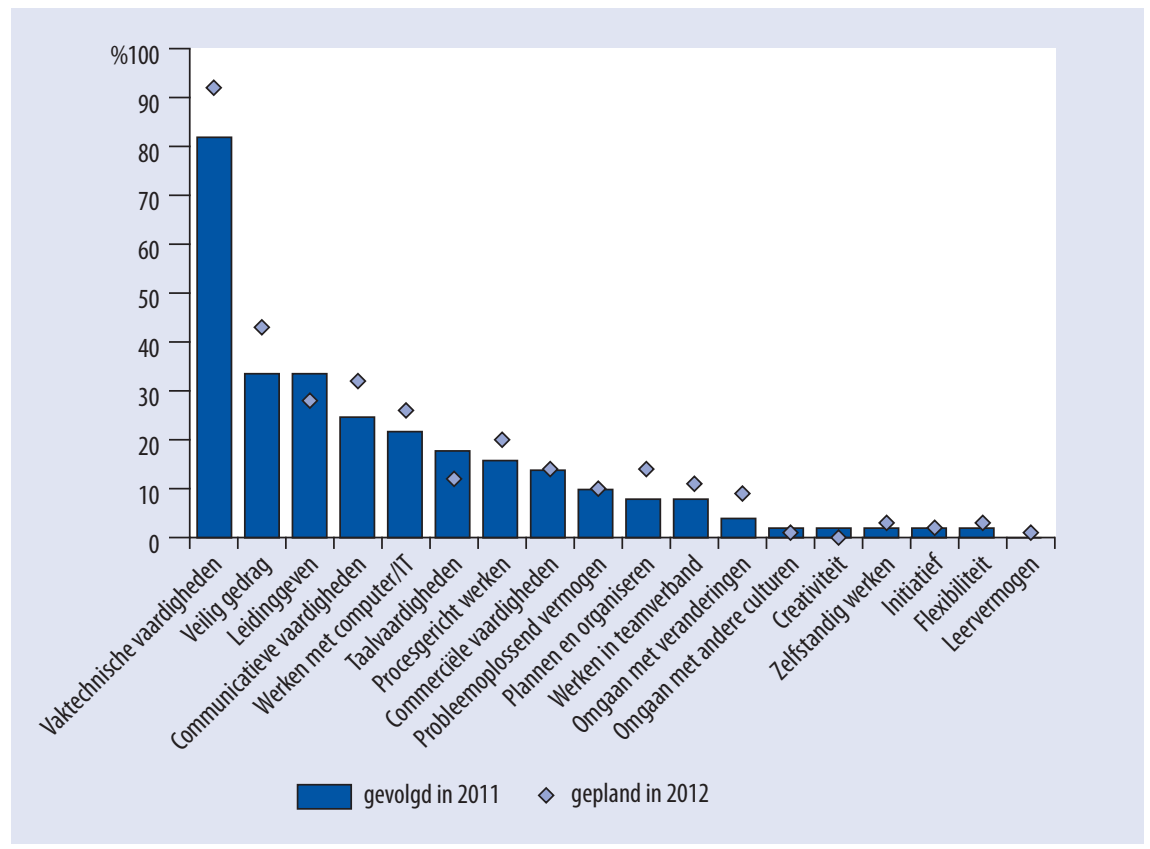

Bron: ROA, Arbeidsmarktmonitor Metalektro, 2011

Bedrijven boden hun technisch personeel in $201 \mathrm{I}$ voornamelijk de mogelijkheid om hun vaktechnische vaardigheden verder te ontwikkelen. In 2011 volgde het technisch personeel in ruim $80 \%$ van de bedrijven vaktechnische scholing. Daarmee ligt dit percentage tussen het niveau van 2009 en 2010 in. Dit percentage overstijgt de verwachting die de bedrijven in 2010 op dit punt hadden voor $201 \mathrm{I}$ ruimschoots. Toen verwachtte namelijk slechts $68 \%$ van de bedrijven dat hun technisch personeel een jaar later een vaktechnische cursus of training zou gaan volgen. In de praktijk lag dit maar liefst $15 \%$-punt hoger. Daarmee is dit de enige cursuscategorie waar bedrijven 
er met hun voorspelling in 2010 behoorlijk naast zaten. Voor het overige deel hebben bedrijven vrij goed voor ogen welke opleidingen zij hun personeel een jaar later willen laten volgen. Dit illustreert dat veel bedrijven aandacht besteden aan hun kennismanagement. Als de verwachtingen van de bedrijven voor 2012 uitkomen zal een nog groter deel (92\%) een vaktechnische cursus gaan volgen. Naast vaktechnische cursussen volgt het technisch personeel in $201 \mathrm{I}$ valk ook trainingen die betrekking hebben op veiligheid, leidinggeven, communicatieve vaardigheden en het werken met computers/IT. Deze opleidingen worden allemaal door meer dan I op de 5 bedrijven genoemd.

Bedrijven verwachten dat er in 2012 enkele duidelijke veranderingen zullen optreden in de scholingsdeelname van hun technisch personeel. Afgaande op de voorspelkracht van de verwachtingen van een jaar eerder lijkt dit een goede indicatie te vormen voor de werkelijke cursusdeelname in 20I2. Voor veruit de meeste cursuscategorieën wordt een lichte toename van de cursusdeelname verwacht. In 2012 zal er volgens de bedrijven in vergelijking met 20II, naast de eerder genoemde vaktechnische opleidingen, vooral meer aandacht besteed worden aan trainingen op het terrein van veiligheid en communicatieve vaardigheden. Er zijn daarentegen ook enkele terreinen waarin de cursusdeelname waarschijnlijk zal afnemen. Zo zullen in 2012 naar verwachting minder technici aan een cursus deelnemen die gericht is op leidinggeven of taalvaardigheden dan in $201 \mathrm{I}$ het geval was.

\section{Belemmeringen die scholing in de weg staan}

Uit figuur 4.2 bleek reeds dat lang niet alle technische medewerkers in 201 i een training of cursus volgden. Bovendien bleek de cursusdeelname in $201 \mathrm{I}$ gedaald te zijn voor zowel arbeidskrachten in vaste loondienst, tijdelijke loondienst als zonder dienstverband. Daarom is het van belang de mogelijke belemmerende factoren die deze scholing momenteel in de weg staan nader te analyseren. Krijgen technici bijvoorbeeld onvoldoende mogelijkheden van hun werkgever om zich te kunnen ontwikkelen, of volgen sommige medewerkers geen scholing omdat zij zelf gewoonweg geen interesse hebben in het volgen van cursussen of trainingen? Figuur 4.6 laat een breed scala aan factoren zien die de scholing van technisch personeel in de weg kunnen staan. Tevens wordt de situatie in 20 II vergeleken met die in 2010.

Meer dan een derde van de bedrijven ervaart in 20 II geen noemenswaardige belemmeringen die de scholing van het technisch personeel in de weg kunnen staan. Een jaar eerder in 2010 ervaarde een kwart geen belemmeringen voor de scholing. Deze op zich positieve ontwikkeling lijkt paradoxaal met de eerder besproken daling van de trainingsdeelname van het technisch personeel. Wanneer meer bedrijven van mening zijn dat er geen belemmerende factoren een rol spelen die de scholing van technici in de weg staan, zou immers verwacht worden dat de cursusdeelname niet zou dalen. Het is echter ook mogelijk dat bedrijven door hun lagere scholingsambities niet meer tegen de eerder ervaren belemmeringen opliepen. 


\section{Figuur 4.6}

Percentage bedrijven met belemmerende factoren voor het scholen van het technisch personeel, 2010-2011

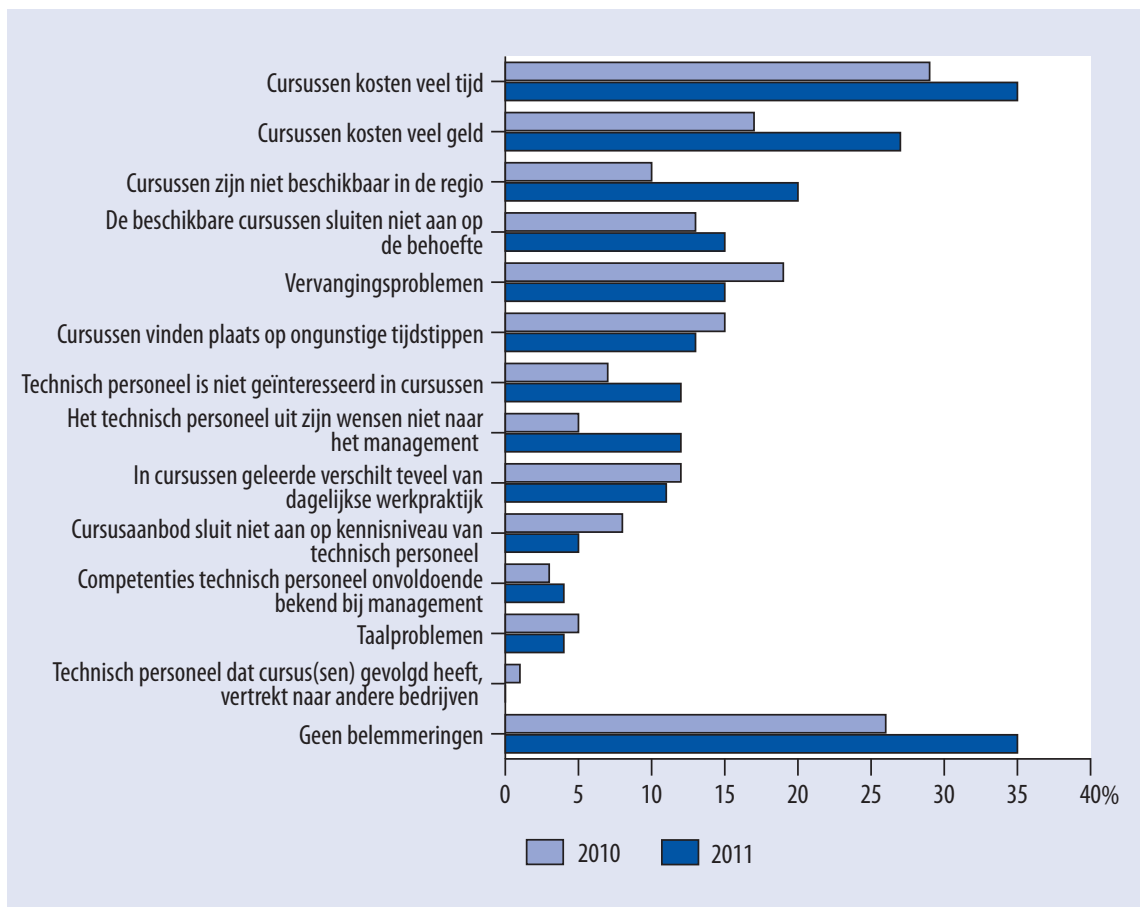

Bron: ROA, Arbeidsmarktmonitor Metalektro, 2010-2011

De drie vaakst voorkomende factoren die de scholing van het technisch personeel in de praktijk in de weg staan zijn in aflopende volgorde van belangrijkheid: de tijd die cursussen in beslag nemen $(35 \%)$, de kosten die hiermee gemoeid gaan $(27 \%)$ en het feit dat bepaalde cursussen niet in de nabijheid van het bedrijf aangeboden worden $(20 \%)$. Met name de twee laatstgenoemde belemmeringen worden in $201 \mathrm{I}$ vaker genoemd dan in 20IO. Ook ervaren bedrijven in $201 \mathrm{I}$ vaker dat het technisch personeel zijn wensen om bepaalde trainingen te volgen niet kenbaar maakt aan het management, dat cursussen te veel tijd kosten en dat het technisch personeel zelf niet geïnteresseerd is in het volgen van cursussen. Vervangingsproblemen staan de cursusdeelname in $201 \mathrm{I}$ juist minder in de weg dan in het jaar ervoor.

Uit de achterliggende informatie blijkt dat bedrijven de betrokkenheid van het technisch personeel bij hun eigen cursusdeelname in de eerste plaats denken te kunnen vergroten door hier meer aandacht aan te besteden tijdens functioneringsgesprekken. Ook wil circa één op de drie bedrijven de betrokkenheid van medewerkers voor hun eigen ontwikkeling stimuleren door de direct leidinggevenden te leren om coachend leiding te geven. Bijna even veel bedrijven willen de motivatie van hun medewerkers om scholing te volgen vergroten door extra inspanningen van $\mathrm{P} \& \mathrm{O}$ op dit punt of 
door medewerkers over te halen elkaar aan te spreken en enthousiast te maken om aan opleidingen deel te nemen. Het blijft echter de vraag in welke mate deze factoren de cursusdeelname in de praktijk daadwerkelijk zullen verbeteren. Dit vraagt namelijk om een cultuuromslag binnen bedrijven en dit is, zeker op de korte termijn, niet altijd even eenvoudig te verwezenlijken.

\subsection{Interne mobiliteit en competentieontwikkeling}

De interne mobiliteit van technisch personeel naar andere functies binnen het bedrijf heeft twee belangrijke doelen. Ten eerste is het een instrument voor de ontwikkeling van de competenties van de medewerkers. Ten tweede betekent doorstroom voor werknemers een loopbaanstap, wat ten goede komt aan de medewerker zelf, maar wat ook de sector als geheel interessant makt om in te gaan werken. Een goede doorstroom van technici kan dus een motiverend effect hebben op de aantrekkingskracht van de sector op de arbeidsmarkt. Indien het mogelijk is om vooruit te komen en carrière te maken, zijn schoolverlaters en technici die werkzaam zijn in een andere sector eerder geneigd om in de Metalektro te gaan werken.

\section{Interne doorstroom of externe doorstroom: de juiste mix}

In één bedrijf zijn de afgelopen jaren veel leidinggevenden vervangen, zowel door interne doorstroom als door instroom van buiten het bedrijf. Bij die vervanging is er op gelet dat de nieuwe leidinggevenden goed kunnen werken volgens de managementfilosofie van het bedrijf, kunnen vertrouwen en 'loslaten', en om kunnen gaan met het nieuwe werken. Zo kan het bedrijf voorbereid worden op toekomstige veranderingen en vernieuwing.

Interne mobiliteit kan betrekking hebben op zowel horizontale als verticale doorstroming. Waar in het eerste geval sprake is van een andere functie op hetzelfde niveau, is in het tweede geval sprake van promotie naar een hogere functie. Beide vormen van interne mobiliteit kunnen ervoor zorgen dat een werknemer niet vastroest in een functie en verbeteren het loopbaanperspectief en de duurzame inzetbaarheid van het personeel. De doorstroom draagt ook in belangrijke mate bij aan het optimaal inzetten van de competenties waarover het personeel beschikt. Onder technische medewerkers is de mobiliteit in de praktijk echter vrij laag. In de helft van de bedrijven is er weliswaar sprake van interne mobiliteit, maar dan gemiddeld voor slechts $4 \%$ van de medewerkers. Deze lage mobiliteit is vaak het gevolg van een vrij hoge specialisatie in de verschillende functies, waardoor er weinig horizontale mobiliteit plaatsvindt. Daarom heeft de interne mobiliteit in de Metalektro vooral betrekking op promoties naar een hoger functieniveau. Bij zes op de tien interne functieveranderingen is dit het geval (figuur 4.7). 
Figuur 4.7

Percentage bedrijven naar niveau waarnaar technische werknemers doorstroomden, 2011

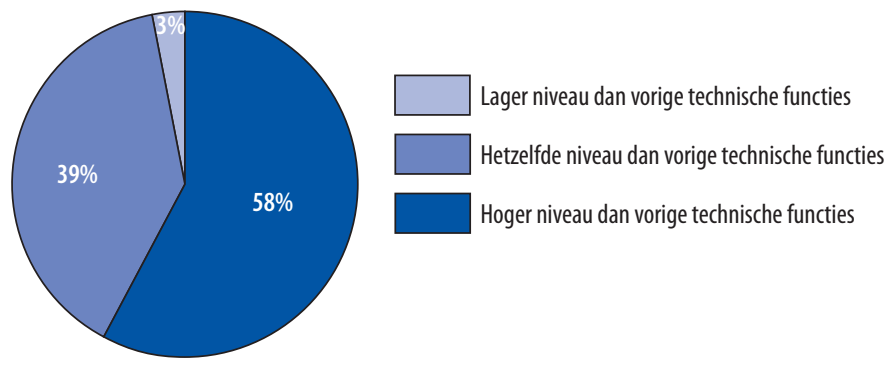

Bron: ROA, Arbeidsmarktmonitor Metalektro, 2011

\subsection{HRM-instrumenten gericht op het loopbaanmanagement}

Tot dusverre lag de focus in dit hoofdstuk op de opleidingsmogelijkheden en competentieontwikkeling van technische medewerkers in de Metalektro. Dit kan echter ook in een breder perspectief geplaatst worden door te kijken naar de HRM-instrumenten die ingezet worden bij het loopbaanmanagement voor het technisch personeel. Het competentiemanagement dat in voorgaande paragrafen besproken werd, vormt een specifiek onderdeel van de loopbaanmanagementcyclus. De hele cyclus bestaat uit (I) het bepalen van het huidige competentieniveau van het personeel (i.e. assessment), (2) het vastleggen van doelen en acties, (3) het volgen van scholing en (4) het opdoen van de gewenste werkervaring. Figuur 4.8 laat voor deze vier componenten van de loopbaanmanagementcyclus zien welke HRM-instrumenten door de bedrijven ingezet worden ten behoeve van hun technisch personeel. Daarnaast staan in dit overzicht twee HRM-instrumenten die niet strikt bij de genoemde onderdelen van loopbaanmanagement thuishoren, maar een rol kunnen spelen over de gehele loopbaanmanagementcyclus. Dit geldt voor zowel de loopbaanplanning als werkoverleggen.

Voor het vaststellen van het huidige niveau van de kennis en vaardigheden van de medewerkers (assessment), maken bedrijven vooral gebruik van informatie die naar voren komt uit functionerings- en beoordelingsgesprekken. Circa driekwart van de bedrijven zet deze HRM-instrumenten in. Voor zowel de functionerings- als de beoordelingsgesprekken geldt dat deze, na een forse daling in 20IO, in 20II weer iets vaker worden ingezet voor het loopbaanmanagement van het technisch personeel.

Om eventuele misverstanden te voorkomen is het verstandig om doelen en acties zwart op wit vast te leggen. Wanneer afspraken worden vastgelegd kan er achteraf tussen werkgever en werknemer geen onduidelijkheid bestaan over de gemaakte afspraken. Dit is dan ook een belangrijk onderdeel van een goed functionerend loopbaanma- 
nagementsysteem. Metalektrobedrijven maken hierbij vooral gebruik van persoonlijke ontwikkelingsplannen (POP's). Afspraken over de ontwikkeling van medewerkers worden in $201 \mathrm{I}$ echter duidelijk minder vaak in een POP vastgelegd dan in de twee jaren ervoor. Daarmee lijkt het groeiende gebruik van dit HRM-instrument in de afgelopen jaren over zijn hoogtepunt te zijn. Ook het bedrijfsopleidingsplan (BOP) lijkt in dit kader al enkele jaren op zijn retour. Terwijl in 2007 nog zes op de tien bedrijven dit HRM-instrument inzetten, waren dit er in $201 \mathrm{I}$ nog maar drie op de tien.

\section{Figuur 4.8}

Percentage bedrijven dat HRM-instrumenten inzet voor de meerderheid van hun technisch personeel, 2010-2011

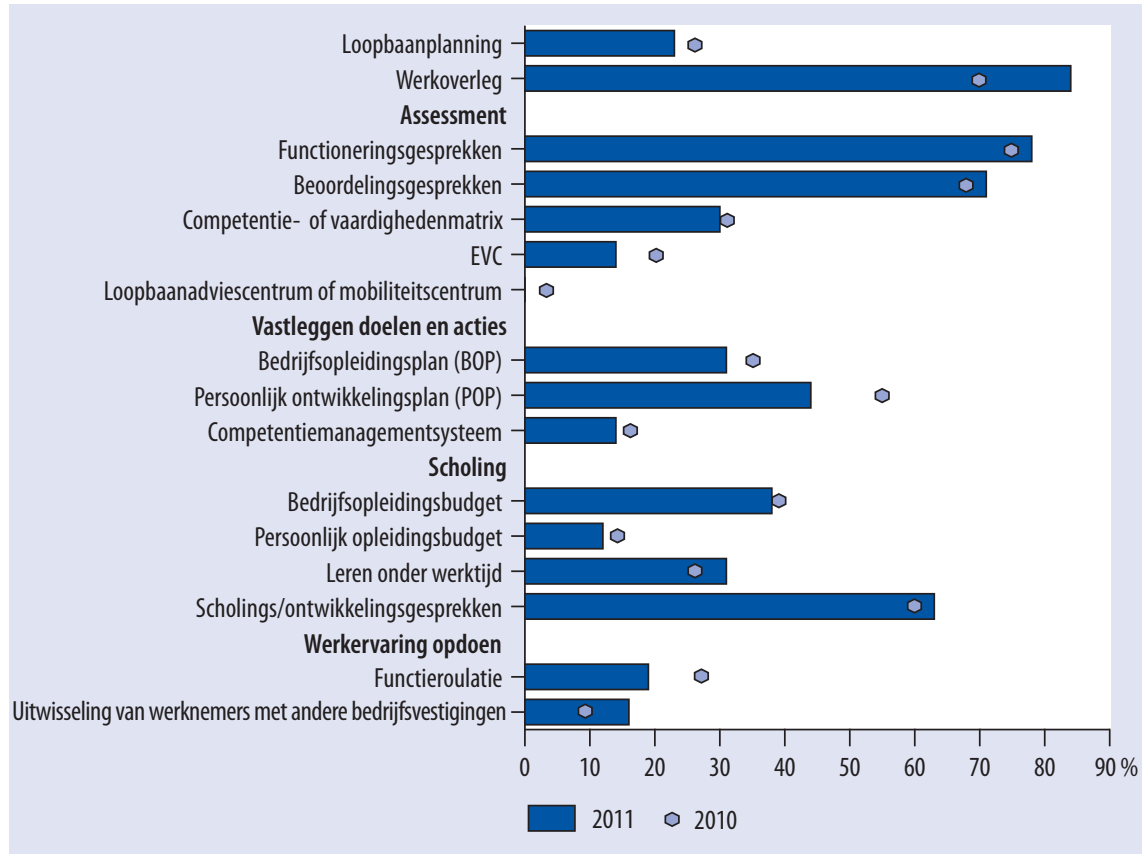

Bron: ROA, Arbeidsmarktmonitor Metalektro, 2010-2011

Uit de figuur blijkt eveneens welk deel van de bedrijven scholings- en ontwikkelingsgesprekken aanbiedt, of tijd en geld beschikbaar stelt om de scholing van het technisch personeel te faciliteren. Zes op de tien bedrijven grijpen scholings- en ontwikkelingsgesprekken aan om scholing te faciliteren. Na een forse daling in 2010 werd dit instrument in $201 \mathrm{I}$ weer iets vaker ingezet. Verder heeft bijna $40 \%$ van de bedrijven een bedrijfsopleidingsbudget en biedt 30\% hun technisch personeel de mogelijkheid om te leren onder werktijd.

Het technisch personeel kan zich eveneens in belangrijke mate verder ontwikkelen door daarvoor relevante werkervaring op te doen. Daarbij kan gedacht worden aan 
het leren door functieroulatie of door de uitwisseling van werknemers met andere bedrijfsvestigingen. Functieroulatie wordt in $201 \mathrm{I}$ duidelijk minder vaak toegepast dan de jaren ervoor toen telkens zo'n 30\% van de bedrijven dit HRM-instrument voor zijn technisch personeel inzette. In vergelijking met een jaar eerder wisselden in $201 \mathrm{I}$ meer bedrijven werknemers uit met andere bedrijfsvestigingen. 



\section{Innovatie in de Metalektro}

De technologische ontwikkeling binnen de Metalektro was in $20 I I$ weer op hetzelfde hoge niveau als in de jaren voor de crisis. Bedrijven twijfelen echter of deze ontwikkeling zich zal voortzetten. Voor de komende vijfjaar wordt er weer een terugval verwacht van het aantal technologische innovaties. Sociale innovaties stonden in 2011 op een lager peil dan in 2010. Hier speelt wellicht mee dat sociale innovatie vaak betrekking heeft op processen die over een langere termijn geïmplementeerd worden. Ook de productiviteitseffecten van sociale innovaties manifesteren zich vaak op langere termijn. Dit verklaart waarom er in $20 I I$ in metalektrobedrijven wat minder nadruk lag op sociale innovatie. Maar voor de komende jaren verwachten veel bedrijven weer meer sociale innovaties door te gaan voeren. Hoe belangrijk sociale innovaties zijn blijkt ook uit de sterke relatie die er bestaat tussen sociale innovaties en technologische innovaties. Meer dan de helft van de bedrijven besteedt ook productieactiviteiten uit aan andere bedrijven. Een aanzienlijk aantal bedrijven verwacht echter de komende jaren minder activiteiten uit te besteden. 


\subsection{Technologische innovaties}

In de Metalektro zijn innovaties cruciaal voor de concurrentiekracht van een bedrijf. Bedrijven veranderen, innoveren en streven er naar dat hun producten en diensten zich op hun afzetmarkten onderscheiden. Technologische innovatie is traditiegetrouw sterk verankerd in deze branche. Daarbij gaat het zowel om productinnovaties en het ontwikkelen van nieuwe vormen van dienstverlening, als om het continu verbeteren van het productieproces. Volgens cijfers van het CBS scoren vooral de machine en de elektrotechnische industrie, en in iets mindere mate de transportmiddelenindustrie, hoog bij het introduceren van innovaties.

In $201 \mathrm{II}$ is het percentage bedrijven dat technologische innovaties heeft doorgevoerd licht gestegen tot $82 \%$. Dit betekent dat technologische innovatie weer min of meer op het niveau ligt dat in de jaren voor de crisis gebruikelijk was (zie Figuur 5.I). Het percentage bedrijven dat ook in 2012 nieuwe innovaties verwacht door te voeren is echter lager. In het lopende kalenderjaar verwacht $72 \%$ van de bedrijven technologische innovaties door te voeren. Het is niet duidelijk of dit een vertraagde uitwerking van de crisis is, waar men wellicht ook de R\&D-uitgaven terugschroefde, of dat dit andere oorzaken heeft.

\section{Figuur 5.1}

Gerealiseerde technologische innovaties (\% bedrijven), 2010-2011

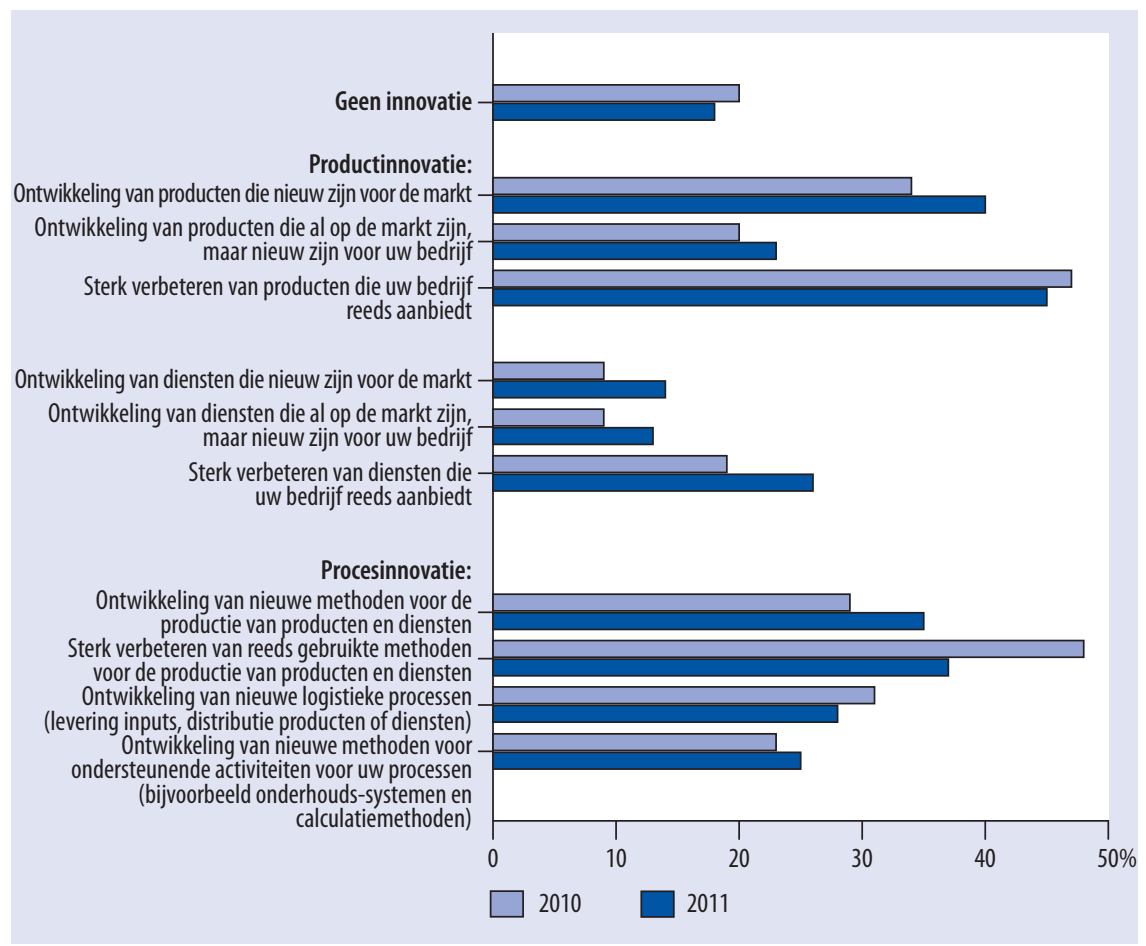

Bron: ROA, Arbeidsmarktmonitor Metalektro, 2010-2011 
De drie belangrijkste technologische innovaties die in $201 \mathrm{I}$ werden doorgevoerd hadden betrekking op:

- de verbetering van reeds bestaande producten;

- de ontwikkeling van nieuwe producten;

- de verbetering van bestaande productieprocessen.

Het percentage bedrijven dat bestaande productieprocessen vernieuwde is echter in $201 \mathrm{I}$ afgenomen. In $20 \mathrm{IO}$ werden deze procesinnovaties namelijk nog door bijna de helft van de bedrijven genoemd; in 201 I nog maar door minder dan $40 \%$ van de bedrijven. Daar staat tegenover dat meer bedrijven nieuwe productiemethoden hebben geïntroduceerd. Ook de positieve trend in het percentage bedrijven dat technologische innovaties implementeert op het gebied van diensten heeft zich doorgezet. Dit illustreert het toenemende belang van innovatieve dienstverleningsconcepten voor veel metalektrobedrijven.

Vooral middelgrote bedrijven blijken sterk in te zetten op het ontwikkelen of verbeteren van nieuwe producten. Daarbij valt regionaal gezien op dat het Westen duidelijk minder goed scoort wanneer rekening gehouden wordt met het type bedrijven. De regio Noord-Oost blijkt daarentegen minder gericht te zijn op service innovaties. Innovaties in de dienstverlening komen vaak voor in de machinebouw en de elektrotechnische industrie. Procesinnovaties worden het meest door grotere bedrijven vanaf Ioo medewerkers doorgevoerd. In de transportmiddelen wordt hieraan de minste aandacht besteed. Bedrijven die sociale innovaties doorvoeren blijken overigens duidelijk beter te scoren bij alle drie de vormen van technologische innovaties (zie paragraaf 5.5).

\section{Innovatie-uitgaven in de technologische industrie}

Uit een recent onderzoek van FME-CWM over de bestedingen van ondernemingen blijkt dat de bestedingen voor innovaties in 2011 hoger lagen dan in 2010. De 157 bedrijven uit de 'technologische industrie' besteden gemiddeld 7\% van hun omzet aan R\&D. Dit resulteert ook in het uitbreiden van het aantal medewerkers dat zich met $R \& D$ bezig houdt. Bedrijven gaven aan dat zij zich vooral op productinnovaties richten. Innovaties op het gebied van de processen of op organisatorisch vlak worden eveneens belangrijk geacht, maar in mindere mate dan de productinnovaties. Deze prioriteit voor het product is vergelijkbaar met de resultaten uit het voorliggende onderzoek van de Arbeidsmarktmonitor.

Bron:Vereniging FME-CWM (2012): Onderzoek Technologie \& Innovatie in de technologische industrie

\subsection{Organisatie en management}

Naast de ontwikkeling van technologische innovaties besteden metalektrobedrijven ook veel aandacht aan sociale innovatie. Het slimmer organiseren van werk- en ontwikkelingsprocessen van bedrijven kan een belangrijke factor zijn om ook op 
product- en productieniveau innovatief en efficiënt te blijven opereren. Een goede bedrijfsorganisatie en -sfeer zijn belangrijke factoren, zo niet absolute voorwaarden, om op nationaal en internationaal vlak concurrerend te kunnen zijn. Voor een bedrijf in een snel veranderende sector, met veel werknemers met uiteenlopende competenties en achtergronden, die bovendien soms werkzaam zijn in verschillende vestigingen van het bedrijf, is een goede organisatie vanzelfsprekend erg belangrijk om goed te kunnen functioneren. Het management van een bedrijf moet dan ook voortdurend de huidige organisatie van het bedrijf toetsen aan nieuwe ontwikkelingen op de markten, en evalueren in het licht van de ervaringen uit het verleden (learning-bydoing). Daarbij moet het management altijd een evenwicht zoeken tussen verandering en stabiliteit: men kan er heel wat mooie ideeën op nahouden over efficiëntere structuren, maar de implementatie ervan kan vaak hoge kosten met zich meebrengen. Veranderingen in de organisatie vergen meestal ook veel energie van werknemers die veel van hun routines moeten loslaten, en te veel veranderingen kunnen bovendien onrust opwekken binnen het bedrijf.

In de vorige arbeidsmarktmonitor werd aangegeven dat er in 20Io, na de turbulente jaren 2008 en 2009, behoefte was om het tempo waarin sociale innovaties worden doorgevoerd ietwat te temperen. Bedrijven wilden kennelijk een rustpauze inlassen in hun sociale innovatiebeleid. Immers, toen er tijdens de crisisjaren minder werk voor handen was en mensen meer openstonden voor veranderingen, ontstond er voor bedrijven een mooie gelegenheid om aanpassingen in de werking en structuur van het bedrijf door te voeren. Zoals figuur 5.2 laat zien, hebben de bedrijven er ook in 20 II voor gekozen de sociale innovaties beperkt te houden. In 2010 gaf $38 \%$ van de bedrijven aan geen enkele vorm van sociale innovaties toe te zullen passen. In 20 II steeg dit percentage zelfs enigszins tot $43 \%$.

\section{Figuur 5.2}

Gerealiseerde sociale innovaties (\% bedrijven), 2010-2011

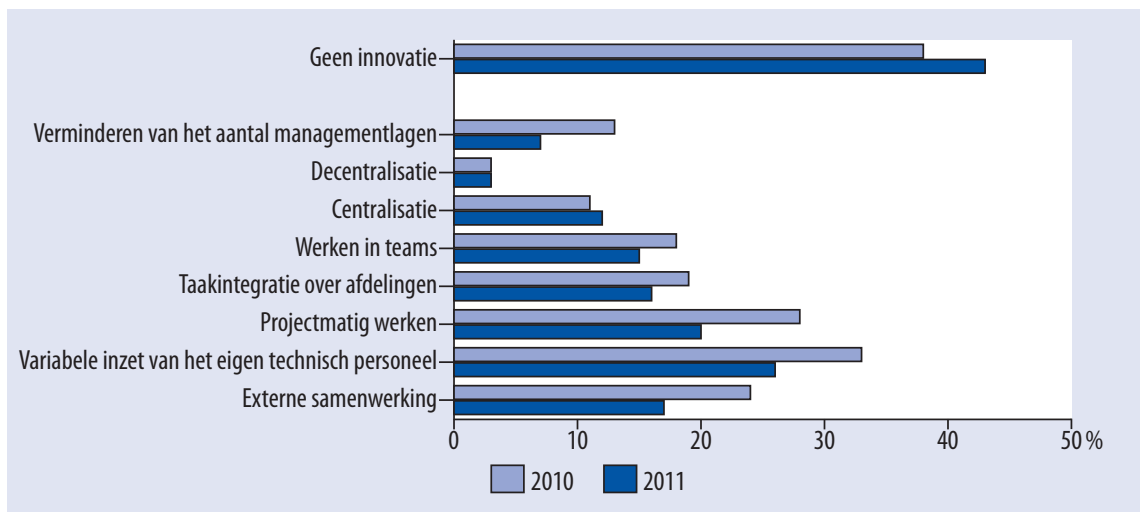

Bron: ROA, Arbeidsmarktmonitor Metalektro, 2010-2011 
In feite zien we dat in $201 \mathrm{I}$ op alle terreinen van sociale innovaties minder bedrijven vernieuwingen doorvoerden. Vooral de behoefte om het aantal managementlagen te verminderen lijkt zeer gering te zijn geworden. In 20 Io had I $3 \%$ van de bedrijven deze intentie, tegenover $7 \%$ in 20 II. Slechts $20 \%$ van de bedrijven zette in 2011 in op het bevorderen van projectmatig werken. In 20 IO was dat nog bij $28 \%$ van de bedrijven het geval. Ook het meer flexibel maken van de werktijden kende in 201 r een terugval, evenals de zoektocht naar nieuwe samenwerkingsverbanden met externe partners. Het percentage bedrijven met nieuwe plannen ter bevordering van de variabele inzet van het eigen personeel, en externe samenwerking, nam tussen 2010 en $201 \mathrm{I}$ af met $7 \%$-punt, respectievelijk van $33 \%$ naar $26 \%$, en van $24 \%$ naar $17 \%$. Zowel in 20 Io als in $201 \mathrm{I}$ waren er nauwelijks bedrijven die bepaalde processen wilden decentraliseren (3\%). Het percentage bedrijven dat in $201 \mathrm{I}$ wilde innoveren op het vlak van werken in teams of het integreren van taken over de afdelingen heen bedroeg zo'n I $5 \%$. In beide gevallen was dat $3 \%$-punt minder dan in 2010 . Alleen het percentage bedrijven dat verder wilde centraliseren kende een lichte toename, van II\% in 2010 naar $12 \%$ in $20 I I$.

$\mathrm{Al}$ met al kan geconcludeerd worden dat metalektrobedrijven in $201 \mathrm{I}$ vooral interesse hadden in sociale innovaties op lagere niveaus, zoals meer projectmatig werken en het (daarbij) meer samenwerken in teamverband. Dit zijn veranderingen die wellicht ook voor minder weerstand zorgen dan veranderingen in de macrostructuur van het bedrijf, die betrekking hebben op de centralisatie en decentralisatie van bepaalde activiteiten of het verminderen van het aantal managementlagen.

Sociale innovaties verlopen in de praktijk uiteraard niet altijd als gepland. In 20 I verliepen veranderingen in de hiërarchische structuren zoals het verminderen van managementlagen, het centraliseren of decentraliseren, in het gros van de gevallen zoals vooropgesteld. Metalektrobedrijven slaagden er in $201 \mathrm{I}$ ook beter in om hun sociale innovaties op dit terrein waar te maken dan in 20I0. Ook plannen ter bevordering van het werken in teams werden in 20 II beduidend vaker uitgevoerd zoals voorzien dan in 20I0. Mogelijk heeft dit te maken met het feit dat veel herstructureringen, die in 2010 nog niet afgerond waren, in $201 \mathrm{I}$ pas volledig uitgevoerd zijn. Vaak duurt het namelijk enige tijd voordat de implementatie van sociale innovaties afgerond kan worden.

De vraag doet zich nu voor of we in de Metalektro op korte en middellange termijn een verlengde organisatorische status quo mogen verwachten, of juist een opleving van een klimaat van sociale innovatie. De verwachtingen van de bedrijven geven aan dat de aandacht voor sociale innovatie de komende jaren wellicht opnieuw zal toenemen (zie Figuur 5.3). Ruim 70\% van de bedrijven zegt in 2012 minstens op één aspect sociaal te zullen innoveren, en dit percentage stijgt tot $80 \%$ voor de periode 2013-2016. Aan nieuwe veranderingen in de algemene hiërarchische structuur, zoals centralisatie en decentralisatie en het verminderen van het aantal managementlagen, lijkt voorlopig nog steeds geen grote behoefte te bestaan. Geplande veranderingen die veel vaker genoemd worden zijn gericht op het bevorderen van het werken in 
teamverband, het integreren van taken over afdelingen heen, de variabele inzet van het eigen technisch personeel en de samenwerking met externe partners. Het huidige economische klimaat verandert echter zeer snel, en het is dan ook interessant om in de volgende edities van de arbeidsmarktmonitor te toetsen in hoeverre eventuele plannen om te innoveren zijn bijgestuurd. De nu genoemde trends komen overigens wel duidelijk overeen met wat de bedrijven in 20 Io aangaven. Veel bedrijven waren toen van plan verdere sociale innovaties door te voeren, maar eerder op de middellange termijn (2OI2-20I5) dan op de korte termijn (2OII).

\section{Figuur 5.3}

Percentage bedrijven met organisatorische veranderingen in 2012, en 2013-2016

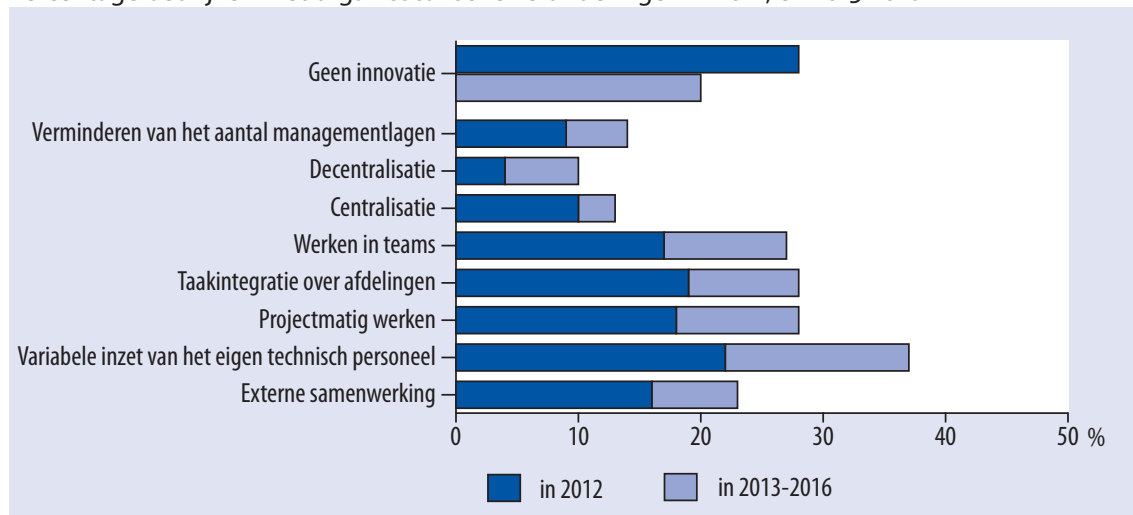

Bron: ROA, Arbeidsmarktmonitor Metalektro, 2011

\subsection{Inzetbaarheid van het personeel}

In hoofdstuk 4 werd uitgebreid ingegaan op de ontwikkeling van menselijk kapitaal. Deze paragraaf zal slechts kort ingaan op de invloed van innovaties op de behoefte aan menselijk kapitaal. Meer in het bijzonder zal ingegaan worden op de behoefte aan en de beschikbaarheid van breed inzetbaar personeel. Evenals in veel andere sectoren is ook in de Metalektro specialisatie een kernbegrip. Bedrijfsstructuren en productieprocessen zijn vaak complex, en voor iedere taak is specifieke expertise nodig. Naast gespecialiseerde vaardigheden en kennis, is er in veel bedrijven echter ook behoefte aan mensen met een brede basis, die routines kunnen loslaten en ingezet kunnen worden waar dat nodig is.

Uit figuur 5.4 blijkt dat de brede inzetbaarheid van het personeel in de meeste bedrijven geen prangend probleem is. Het overgrote deel van de bedrijven zegt voldoende breed inzetbaar personeel te hebben voor technisch opgeleide verkopers, leidinggevende en ondersteunende technische en niet-technische functies. Een groter probleem lijkt er op dit punt te bestaan bij het uitvoerend technisch personeel. Meer dan een kwart van 
de bedrijven heeft behoefte aan een bredere inzetbaarheid van hun uitvoerend technisch personeel en zou dus willen dat deze werknemers hun kennis en vaardigheden bijspijkeren die het mogelijk maken om werkzaamheden te verrichten die buiten hun (vaak zeer specifieke) standaard takenpakket vallen. Het gaat daarbij vaak niet alleen om het bijschaven of verbreden van vaktechnische kennis of vaardigheden, maar ook over het overwinnen van drempelvrees. Een lasser die plots op een andere afdeling moet inspringen moet, als hij dat nog niet eerder heeft gedaan, immers ook zijn onzekerheid kunnen overwinnen.

Figuur 5.4

Brede inzetbaarheid van het personeel in 2011 (\% bedrijven)

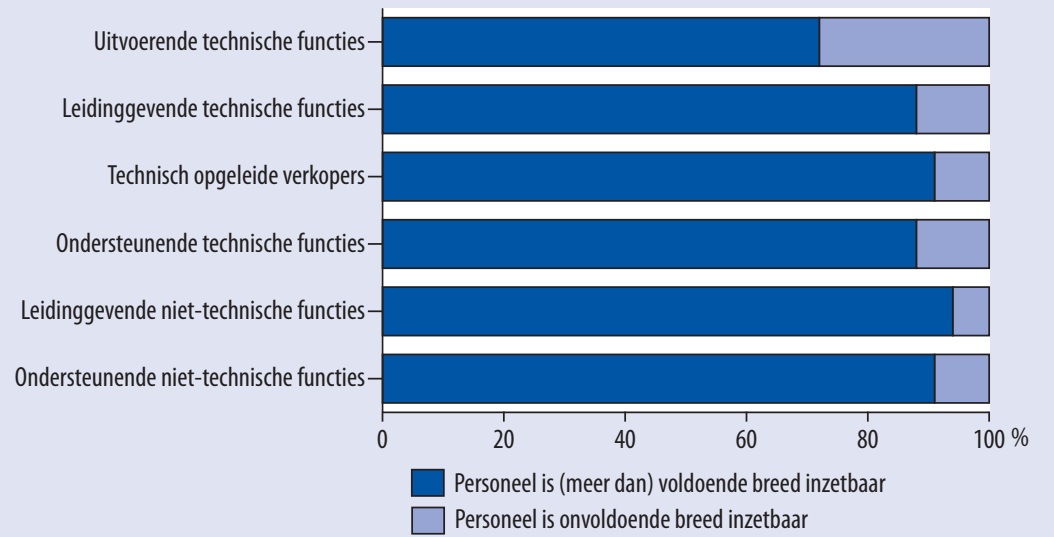

Bron: ROA, Arbeidsmarktmonitor Metalektro, 2011

Om de knelpunten in de inzetbaarheid beter te kunnen kaderen en analyseren, werd aan de bedrijven ook gevraagd waarom brede inzetbaarheid werd verlangd. Bijna de helft van de bedrijven gaf in 2010 en 2011 aan dat brede inzetbaarheid vaak wenselijk is omwille van de continue proces- en productinnovatie. Schommelingen in de vraag lijken echter de belangrijkste bron van behoefte aan brede inzetbaarheid te zijn: meer dan twee derde van de bedrijven geeft deze reden op en in de periode 200520 Io was dit aandeel bedrijven vaak nog veel groter. Daarnaast zijn er nog tal van andere redenen waarom brede inzetbaarheid belangrijk kan zijn. Hierbij kan gedacht worden aan het aantrekkelijker maken van de baan door variatie in de taken aan te brengen, tekorten op te vangen van bepaalde categorieën werknemers, ziekteverzuim tegen te gaan of uitstroom door vergrijzing of afwezigheid door vakantie op te vangen. Ook kan voor sommige bedrijven brede inzetbaarheid belangrijk zijn om kosten te besparen en voor het uitvoeren van eenmalige werkzaamheden. In vergelijking met 20 o lijken vooral het bestrijden van ziekteverzuim en de voorkeuren van werknemers zelf voor meer divers werk factoren te zijn die aan belang toenamen. Het belang van brede inzetbaarheid omwille van kostenbesparing lijkt te zijn afgenomen: deze reden wordt door een derde minder aangegeven in $201 \mathrm{I}$ ten opzichte van 2010. 


\subsection{Outsourcing}

In een geglobaliseerde economie is een goede integratie in de internationale markt cruciaal voor de competitiviteit, en dat geldt ook voor de Metalektro. Een belangrijke factor in dit proces is specialisatie in taken en uitbesteding van taken indien dit, op termijn, de kostenefficiëntie verhoogt. In deze paragraaf wordt dan ook gekeken in hoeverre taken in de Metalektro worden uitbesteed en welke trends zich daarbij voordoen.

Figuur 5.5 laat zien dat veel metalektrobedrijven activiteiten uitbesteden. Daarbij gaat het ook in 2OII vooral om productieactiviteiten in de supply chain. Meer dan de helft van de bedrijven besteedt bepaalde productieactiviteiten uit aan andere bedrijven. Een kwart heeft hiervoor toeleveranciers buiten Nederland gezocht. Verder doet ruim een derde van de bedrijven voor ondersteunende activiteiten een beroep op derden. Meestal zoekt men dan wel naar een binnenlandse partner. Voor andere taken zoals administratie en onderzoek blijft de outsourcing, evenals in voorgaande jaren, eerder beperkt.

Figuur 5.5

Uitbestede activiteiten (\% bedrijven), 2011

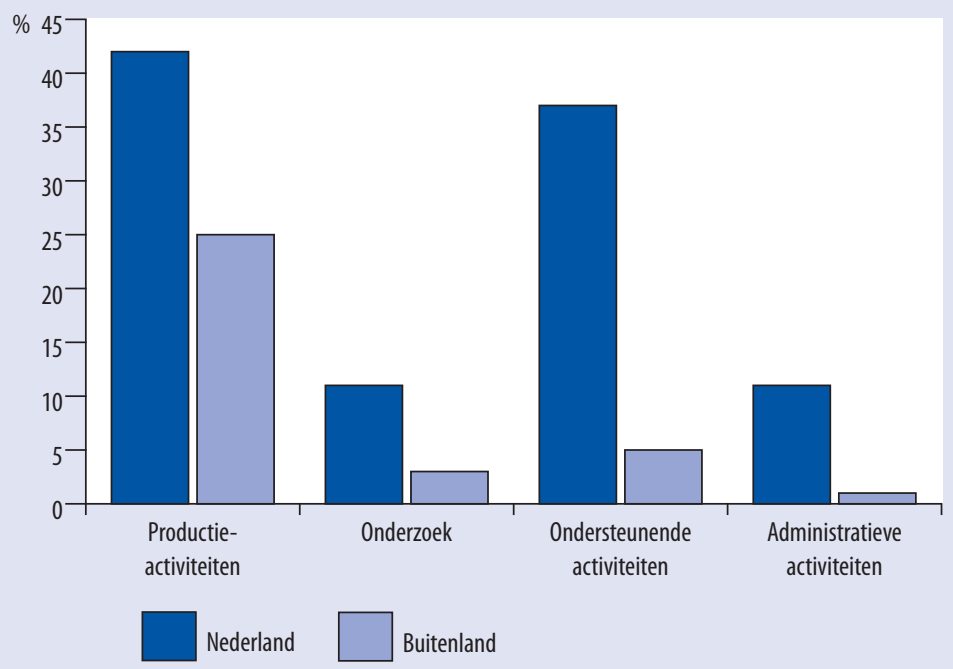

Bron: ROA, Arbeidsmarktmonitor Metalektro, 2011

Voor al deze taken verwacht het overgrote deel van de bedrijven voor de komende jaren geen verandering in het uitbestedingspatroon (zie Figuur 5.6). Zo denkt bijna drie kwart van de bedrijven dat hun strategie voor het uitbesteden van productieactiviteiten de komende vijf jaar niet zal veranderen. Bij de andere terreinen van outsourcing ligt dit percentage nog hoger. Het is echter wel opmerkelijk dat, hoewel het een minderheid van de bedrijven betreft, toch een aanzienlijk aantal bedrijven verwacht 
de outsourcingactiviteiten af te bouwen. Een kleine $20 \%$ die momenteel een deel van de productieactiviteiten uitbesteedt aan bedrijven binnen Nederland wil deze uitbestedingen terugschroeven. Bij de bedrijven die de productie (deels) uitbesteden aan buitenlandse bedrijven is dat zelfs een kwart. Daartegenover zijn er maar weinig bedrijven die van plan zijn hun bestaande uitbestedingen verder uit te breiden.

\section{Figuur 5.6}

Verwachte verandering in outsourcing (\% bedrijven), 2012-2016

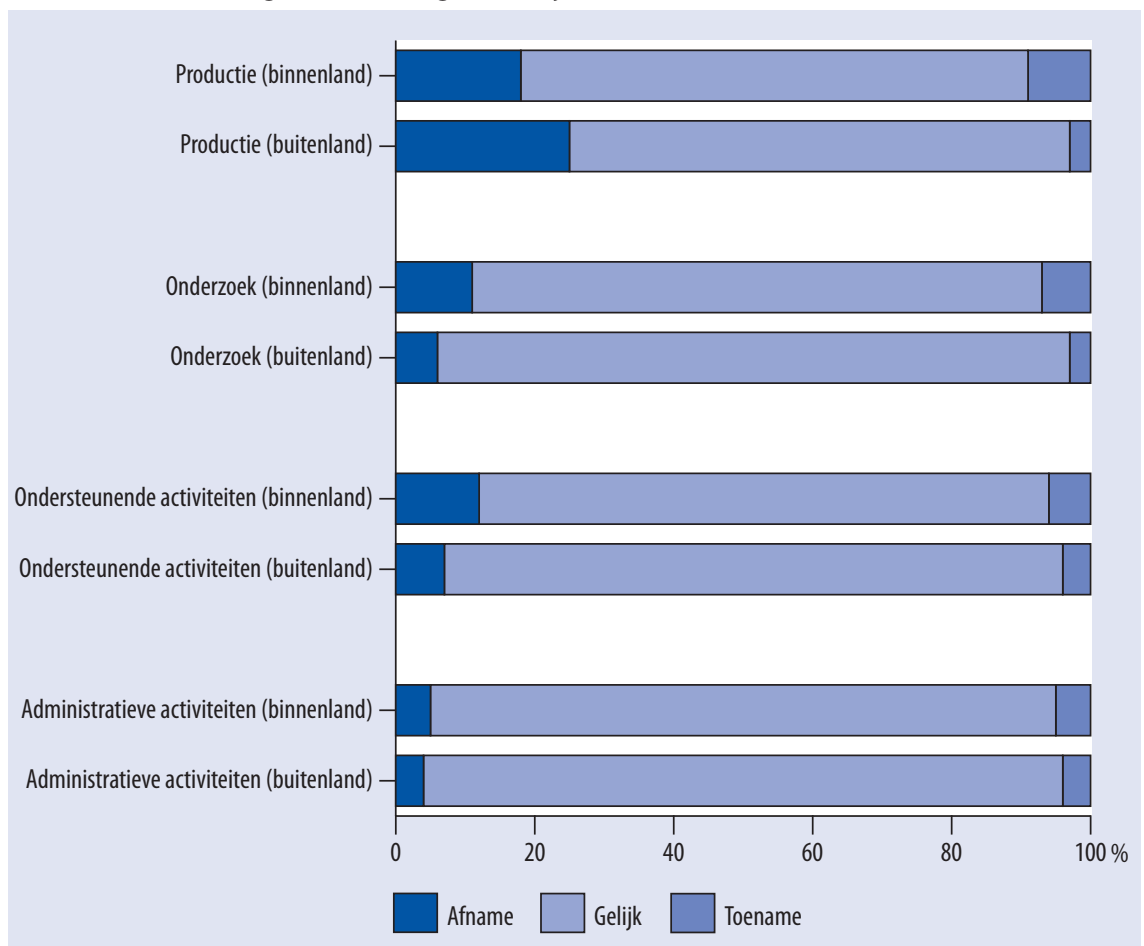

Bron: ROA, Arbeidsmarktmonitor Metalektro, 2011

\subsection{Het verband tussen sociale en technologische innovatie}

Sociale innovatie is voor de Metalektro uiteraard geen doel op zich, maar een middel tot het bereiken van een hogere productiviteit en grotere concurrentiekracht. Daarbij kunnen sociale innovaties bovendien leiden tot meer technologische innovatie. De onderstaande analyses laten zien dat er inderdaad een verband bestaat tussen de sociale en technologische innovativiteit van een bedrijf. Bedrijven met sociale innovaties hebben vaker technologische innovaties en deze zijn bovendien meer vernieuwend. 
Zoals in het begin van het hoofdstuk werd aangegeven, kan er een onderscheid gemaakt worden tussen technologische innovaties die betrekking hebben op (I) innovatie van producten, (2) innovatie van diensten en (3) innovatie van productieprocessen. Regressieanalyses waarbij het al dan niet doorvoeren van deze drie types technologische innovatie wordt verklaard door de mate waarin het bedrijf sociale innovaties doorvoert geven een eenduidig resultaat: zij laten zien dat er inderdaad sprake is van een positief en substantieel verband tussen sociale innovatie en technologische innovatie. Bedrijven die sociaal innoveren hebben ruim $20 \%$-punt meer kans om productinnovaties of procesinnovaties door te voeren en zelfs ruim 30\%-punt meer kans om aan service innovatie te doen. Hieruit blijkt dat technologische en sociale innovaties elkaar in belangrijke mate aanvullen.

Uiteraard kan men zich hierbij afvragen wat het precieze mechanisme is achter de samenhang tussen technologische en sociale innovaties. Zijn het de sociale innovaties die een goed klimaat creëren voor technologische innovatie? Of zijn het bijvoorbeeld eerder de grote bedrijven waarvoor sociale innovatie belangrijk is, omdat ze complexer zijn om te managen, terwijl deze grote bedrijven ook meer middelen hebben om innovatief te zijn op technologisch vlak? Er zijn inderdaad andere factoren die zowel positief samenhangen met sociale innovatie als met technologische innovatie. Kleinere bedrijven doen aanzienlijk minder aan productinnovatie of procesinnovatie, maar doen ook minder aan sociale innovatie.

Tabel 5.I geeft een overzicht van de resultaten van regressieanalyses, waarin rekening wordt gehouden met de grootte van het bedrijf, de regio waar het bedrijf gevestigd is en de sector waarin het bedrijf actief is. De tabel laat zien dat de relatie tussen sociale innovatie en de verschillende vormen van technologische innovatie erg groot is. Sociale innovatie vergroot de kans dat een bedrijf aan technologische innovatie doet met 20 tot 30\%-punt. Sociale innovaties leiden tot meer creativiteit in de organisatie en stimuleren daarmee de technologische vernieuwing.

Tabel 5.1

Relatie tussen technologische innovaties en sociale innovaties (waarbij rekening wordt gehouden met de grootte van het bedrijf, de regio en de sector), 2011

\begin{tabular}{|c|c|c|c|}
\hline & Product & Service & Proces \\
\hline Bedrijf heeft sociale innovaties doorgevoerd & ++ & ++ & ++ \\
\hline Grootte & Ja & Ja & $\mathrm{Ja}$ \\
\hline Branche & Ja & Ja & $\mathrm{Ja}$ \\
\hline Regio & Ja & Ja & $\mathrm{Ja}$ \\
\hline \multicolumn{4}{|c|}{$\begin{array}{l}\text { Noot: In deze analyses is gekeken naar de mate van innovativiteit: innovatie op wereldmarkt (3), } \\
\text { nieuw voor Nederland ( } 2 \text {, nieuw voor het bedrijf (1), geen innovaties (o). De resultaten geven } \\
\text { telkens een beeld van het verschil met de referentiegroep. Daarbij is achtereenvolgens als refe- } \\
\text { rentiegroep gekozen voor grote bedrijven met meer dan } 250 \text { medewerkers, bedrijven in de regio } \\
\text { Zuid, bedrijven in de sector 'Overig'. De resultaten zijn weergegeven in termen van statistische } \\
\text { verbanden: ++ geeft sterke positieve significante verbanden weer. }\end{array}$} \\
\hline
\end{tabular}


Een goed management en een goede aansluiting van de taken die medewerkers uitvoeren op hun voorkeuren en capaciteiten kunnen een belangrijke impact hebben op de motivatie en baantevredenheid van werknemers. Recent onderzoek heeft via laboratoriumexperimenten overtuigend aangetoond dat mensen die beter in hun vel zitten veel productiever zijn. Dat een lage baantevredenheid een goede voorspeller is voor een hoog arbeidsverloop, is reeds uitgebreid gedocumenteerd in de vakliteratuur. Aandacht voor een bedrijfssfeer waarbij werknemers zich goed in hun vel voelen, is dus niet alleen goed voor de medewerkers zelf. Het kan ook voor het bedrijf een hoog rendement opleveren.

Ook door taken uit te besteden en door samen te werken met nationale en internationale partners kan er nieuwe knowhow het bedrijf binnenstromen. Zo heeft de recente vakliteratuur op het vlak van internationale economie herhaaldelijk aangetoond dat bedrijven veel leren door te exporteren, omdat er vaak belangrijke 'knowhow' wordt overgedragen tussen bedrijven die samenwerken in de supply chain of in allianties met betrekking tot 'research \& development'. 



\section{Duurzame inzetbaarheid}

Duurzame inzetbaarheid binnen de Metalektro verdient alle aandacht, zeker met het oog op de dreigende toekomstige tekorten aan technici. Bedrijven verwachten dat de komende jaren vooral veel uitvoerende technici met pensioen zullen gaan. Opvallend is daarbij de sterk dalende trend bij alle vier de technische functiecategorieën. Dit houdt waarschijnlijk verband met de latere leeftijd waarop medewerkers met pensioen gaan.

Metalektrobedrijven geven aan dat zij de komende jaren de grootste problemen verwachten bij hun zoektocht naar nieuwe uitvoerende technici en leidinggevende technici die de medewerkers die met pensioen gaan moeten vervangen. In $20 I I$ stijgt in alle technische functiecategorieën het percentage bedrijven dat veel vervangingsproblemen voorziet bij het invullen van vacatures die ontstaan door pensionering van technici. Wel lijkt de meerderheid doordrongen van het belang om hier beleidsmatig op in te spelen. De twee meest toegepaste HRM-instrumenten op dit gebied hebben betrekking op het aantrekken van nieuwe medewerkers. Het vaakst worden nieuwe medewerkers aangenomen die vervolgens zelf worden opgeleid of die reeds goed opgeleid zijn.

Veel metalektrobedrijven voeren bovendien een leeftijdsbewust of levensfasebewust beleid om hun personeel duurzaam inzetbaar te houden. Dit betekent dat zij tijdens hun gehele carrière zo goed mogelijk productief inzetbaar blijven. Daartoe nemen deze bedrijven maatregelen die erop gericht zijn medewerkers productief, gemotiveerd en gezond te houden. 


\subsection{Uitstroom vanwege pensionering}

$\mathrm{Nu}$ de babyboomgeneratie langzaam maar zeker de pensioengerechtigde leeftijd bereikt zal een substantieel deel van deze groep vervangen moeten worden. Daarom is het van groot belang dat bedrijven hier tijdig op inspelen en hier beleidsmatig op anticiperen, zodat zij achteraf niet voor verrassingen komen te staan. Een belangrijk onderdeel van dit proces is het in kaart brengen van de verwachte personeelsuitstroom op korte en middellange termijn. Op basis hiervan kunnen bedrijven bepalen welk deel van deze uitstroom vervangen moet worden door nieuwe medewerkers. De verwachte uitstroom, maar ook de gewenste toekomstige inhoud van verschillende functies en de gewenste competenties van werknemers kunnen nogal verschillen van de huidige situatie. Ook kan de verwachte personeelsuitstroom behoorlijk uiteenlopen tussen de verschillende functiecategorieën.

\section{Figuur 6.1}

Verwacht aandeel medewerkers dat de komende vijf jaar met pensioen gaat per technische functiecategorie, 2007-2011

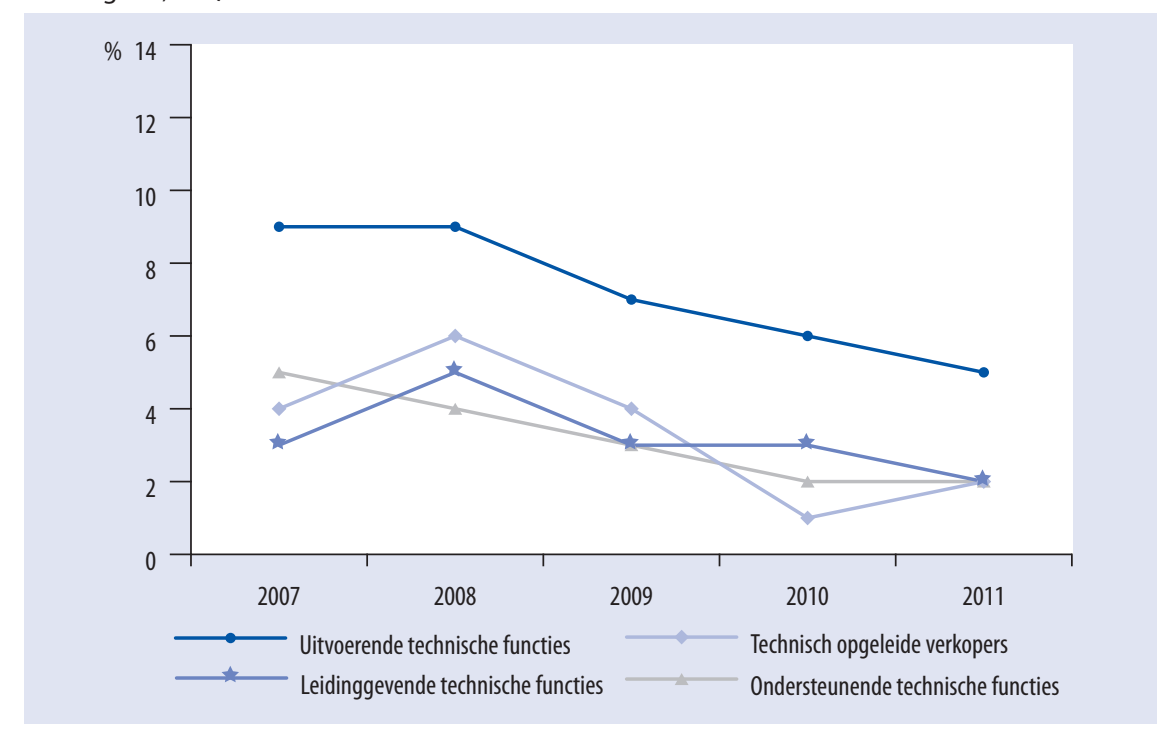

Bron: ROA, Arbeidsmarktmonitor Metalektro, 2007-2011

Figuur 6.I laat voor de verschillende technische functies zien welk deel van het personeel de komende vijf jaar naar verwachting met pensioen zal gaan. Tussen 2007 en 2OII verwachten de metalektrobedrijven vooral dat er binnen vijf jaar veel medewerkers die werkzaam zijn in de uitvoerende technische functies met pensioen zullen gaan. Opvallend is echter dat er in deze periode sprake is van een sterk dalende trend. In 2007 was de algemene verwachting dat 9\% van de uitvoerende technici tussen 2008 en 2012 met pensioen zou gaan. In $201 \mathrm{I}$ is dit percentage gehalveerd en zal naar verwachting 4,6\% binnen vijf jaar de Metalektro verlaten vanwege pensionering. 
Ook in de andere technische functiecategorieën verwachten bedrijven in $201 \mathrm{I}$ voor de komende vijf jaar een lage uitstroom vanwege pensionering. Zowel voor de technisch opgeleide verkopers, de leidinggevende technische functies als de ondersteunende technische functies wordt verwacht dat zo'n $2 \%$ van de medewerkers binnen vijf jaar met pensioen gaat. Daarmee is de verwachte uitstroom van oudere medewerkers duidelijk lager dan voor de crisis. Dit illustreert het feit dat arbeidskrachten de laatste jaren langer doorwerken. Cijfers van CBS laten zien dat de gemiddelde pensioenleeftijd van werknemers in 201 is opgelopen tot ruim 63 jaar. In 2006 was dit bijvoorbeeld nog gemiddeld 6I jaar. Dit betekent dat oudere medewerkers langer voor de arbeidsmarkt beschikbaar blijven. Dit houdt echter tegelijkertijd in dat dit percentage op termijn weer hoger zal worden, want deze ontwikkeling zorgt feitelijk alleen voor uitstel van pensionering.

\subsection{Vervangingsproblemen}

Uitstroom van technisch personeel hoeft niet noodzakelijkerwijs tot vervangingsproblemen te leiden. Wanneer het economisch gezien slechter gaat kunnen bedrijven er immers voor kiezen deze uitstroom voorlopig niet te vervangen. Dit is bijvoorbeeld het geval als er overcapaciteit is, of als er te veel onzekerheid is of er nog wel voldoende orders binnen zullen komen. Daar staat tegenover dat bedrijven die verwachten dat er maar weinig medewerkers met pensioen gaan toch veel problemen kunnen ervaren bij het invullen van de vrijgekomen vacatures. Dit is bijvoorbeeld het geval als er onvoldoende geschikte werknemers voor deze functies op de arbeidsmarkt beschikbaar zijn. Het gaat immers niet alleen om de vraag naar arbeid, maar eveneens om het aanbod dat voor handen is om een goede match te kunnen maken.

In figuur 6.2 wordt voor de periode 2007-20II nagegaan in hoeverre bedrijven verwachten dat er veel vervangingsproblemen zullen ontstaan door het vertrek van technische medewerkers die de komende vijf jaar met pensioen gaan. Ook hier wordt een uitsplitsing gemaakt naar de verschillende technische functiecategorieën. Evenals in 20IO, geven de bedrijven in $201 \mathrm{I}$ aan dat zij de komende jaren de grootste problemen verwachten bij het aantrekken van nieuwe uitvoerende technici en leidinggevende technici ter vervanging van oudere medewerkers die met pensioen gaan. Bijna een derde van de bedrijven verwacht veel problemen bij de vervanging van gepensioneerde medewerkers uit deze functiecategorieën. In alle technische functiecategorieën stijgt het percentage bedrijven dat in $201 \mathrm{I}$ veel vervangingsproblemen voorziet bij het vervullen van vacatures die ontstaan door pensionering van technici ten opzichte van 20IO. Eerder was vooral de aanzienlijke daling van het percentage bedrijven dat vervangingsproblemen verwacht in 2009 opvallend. Door de crisis kelderde het aantal dat veel vervangingsproblemen verwacht. Ondanks de toename van de verwachte vervangingsproblemen in $2 \mathrm{OII}$, is het percentage dat vervangingsproblemen verwacht bij de uitstroom van medewerkers die met pensioen gaan in alle functiecategorieën nog steeds veel lager dan net voor de crisis in 2008. 


\section{Figuur 6.2}

Ontwikkeling aandeel bedrijven dat in de komende vijf jaar veel vervangingsproblemen verwacht door pensionering, per technische functiecategorie, 2007-2011

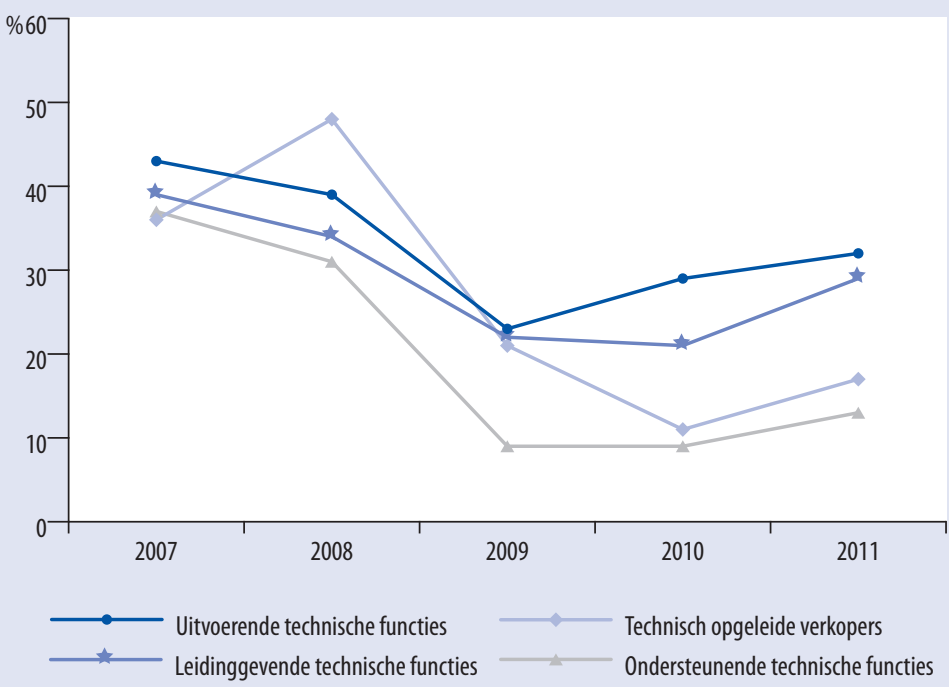

Bron: ROA, Arbeidsmarktmonitor Metalektro, 2007-2011

De vervangingsproblematiek verschilt duidelijk per regio. In de regio Noord/Oost is het percentage bedrijven dat de komende vijf jaar veel vervangingsproblemen verwacht door pensionering van uitvoerende technici en technisch opgeleide verkopers in $20 \mathrm{II}$ aanzienlijk kleiner dan in de regio's West en Zuid. Bedrijven in het Westen van het land verwachten juist vaker dat er veel problemen zullen ontstaan bij de vervanging van leidinggevende technici die met pensioen gaan. In het Westen verwacht bijna de helft van de bedrijven veel problemen bij de vervanging van gepensioneerde leidinggevende technici.

\subsection{Aanpak vervangingsproblemen}

Bedrijven denken verschillend over hoe zij de vervangingsproblemen die ontstaan door de vergrijzing van het technisch personeel willen aanpakken. Wel lijkt de meerderheid doordrongen van het belang om deze verwachte vervangingsproblematiek adequaat aan te pakken. Op de vraag of bedrijven in $201 \mathrm{I}$ al maatregelen nemen, ofwel van plan zijn maatregelen te gaan nemen, om de vervangingsproblemen van gepensioneerde technici te beperken, antwoorden 6 op de ro bedrijven bevestigend. In 2007 en 2008 gold dit nog voor 7 op de Io bedrijven. Hoewel het merendeel van de bedrijven dus reeds maatregelen neemt, of denkt te gaan nemen, om de problemen vanwege de uitstroom van oudere technische medewerkers te beperken, betekent dit eveneens dat een aanzienlijk deel van de bedrijven dit kennelijk niet belangrijk genoeg 
vindt om in te grijpen. Figuur 6.3 laat zien welke HRM-maatregelen in $201 \mathrm{I}$ al werden toegepast om deze problemen te ondervangen. Bovendien blijkt uit deze figuur welke maatregelen bedrijven in dit kader de komende vijf jaar denken te gaan nemen.

\section{Figuur 6.3}

HRM-maatregelen om problemen met vervanging van gepensioneerde technici te beperken (\% bedrijven), 2011

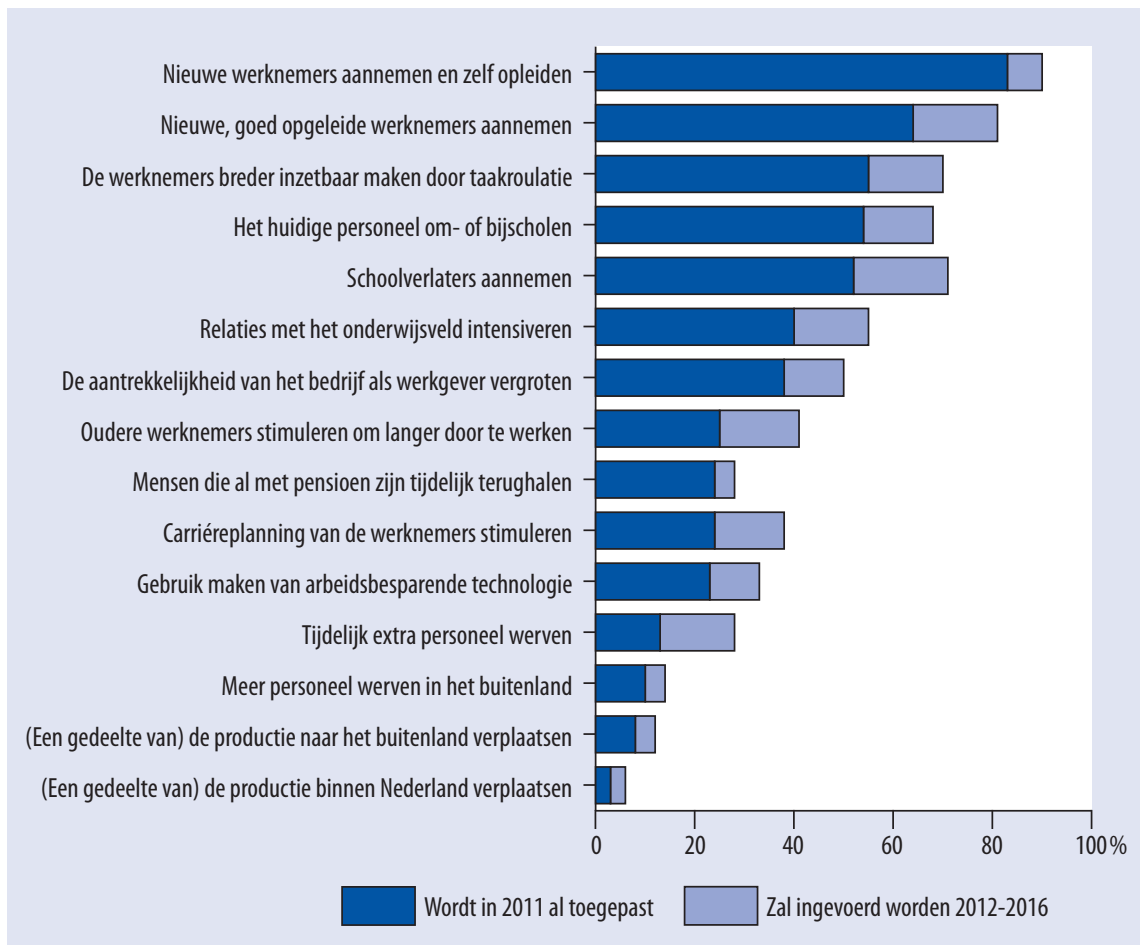

Bron: ROA, Arbeidsmarktmonitor Metalektro, 2011

De twee meest genoemde HRM-maatregelen die nu al worden toegepast hebben betrekking op het aantrekken van nieuwe medewerkers. Het vaakst worden nieuwe medewerkers aangenomen die vervolgens zelf opgeleid worden. Dit wordt door ruim $80 \%$ nu al toegepast. Veel bedrijven proberen ook nieuwe medewerkers aan te trekken die reeds goed opgeleid zijn. Op plaats drie en vier volgen maatregelen die de inzetbaarheid van het huidige personeel verbeteren. Zo worden medewerkers vaak breder inzetbaar gemaakt door taakroulatie of krijgen ze de mogelijkheid om zich om of bij te scholen. Op de vijfde plaats staat het aantrekken van schoolverlaters. In vergelijking met 2010 trachten bedrijven in toenemende mate om de aantrekkelijkheid van het bedrijf te vergroten om personeel aan te trekken, schoolverlaters aan te trekken en nieuwe medewerkers aan te nemen en deze vervolgens zelf verder op te leiden. 
Wanneer bedrijven in de toekomst daadwerkelijk voet bij stuk houden en ook echt de HRM-maatregelen nemen die zij zeggen te gaan nemen, dan zal de komende jaren vooral de strijd om de schoolverlaters losbarsten. Bij één op de vijf zal tussen nu en vijf jaar meer aandacht komen te liggen op het aantrekken van schoolverlaters. Hoewel vanzelfsprekend niet van schoolverlaters verwacht kan worden dat zij hetzelfde niveau qua kennis en vaardigheden hebben als oudere medewerkers, zien bedrijven zich hier kennelijk toch toe genoodzaakt. Daarnaast ligt de nadruk op de middellange termijn op het aantrekken van nieuwe medewerkers die reeds goed opgeleid zijn en het stimuleren van oudere medewerkers om langer door te werken. Puur als laatste redmiddel denken bedrijven pas terug te hoeven grijpen naar werving in het buitenland, verplaatsing van de productie en het tijdelijk terughalen van reeds gepensioneerden.

Een belangrijke HRM-maatregel om problemen met de vervanging van gepensioneerde technici op te vangen bestaat uit het om- of bijscholen van het personeel dat al bij het bedrijf werkzaam is (zie bijvoorbeeld figuur 6.3). Een veel gehoord probleem in de praktijk is de lagere trainingsparticipatie van ouderen. Werkgevers geven aan dat veel oudere werknemers er zelf helemaal niet voor open staan om nog een cursus of training te volgen. Probleem hierbij is dat het opleiden van oudere werknemers ook minder effectief blijkt te zijn en dat zij minder ambitieuze doelstellingen nastreven dan hun jongere collega's. Volgens Zwick (2011) wordt dit veroorzaakt doordat oudere medewerkers zowel qua vorm als inhoud vaak de verkeerde training krijgen aangeboden. Zij leren meer van praktische en informele trainingen die direct relevant voor zijn voor hun werk en waarbij de inhoud van de training voortbouwt op de competenties die zij eerder hebben verworven. Wanneer werkgevers in de Metalektro hier rekening mee houden kan dit de resultaten van trainingen aan oudere medewerkers verbeteren.

Figuur 6.4 geeft een overzicht van de ontwikkeling van de drie meest genomen HRM-maatregelen om vervangingsproblemen tegen te gaan in de jaren 2007-20II. In lijn met de verwachting kent het aantrekken van nieuwe werknemers, zowel degenen die goed opgeleid zijn als degenen die zelf nog opgeleid moeten worden, een dip tijdens de crisis. Maar in beide gevallen stijgt dit percentage weer bij het aantrekken van de economie. De om- en bijscholing van het zittende personeel laat juist een heel ander verloop zien. Hier valt het anticyclische karakter van deze HRM-maatregel op. Veel metalektrobedrijven gingen tijdens de crisis meer investeren in het eigen personeel. Ten dele speelt hierbij ook dat zij hier min of meer toe gestimuleerd werden, omdat het opstellen van een scholingsplan een voorwaarde was voor bedrijven die in aanmerking wilden komen voor deeltijd-WW. In $201 \mathrm{I}$ is de situatie zoals deze in 2007 was weer min of meer hersteld. 


\section{Figuur 6.4}

Ontwikkeling van HRM-maatregelen die het meest toegepast worden om problemen met de vervanging van gepensioneerde technici te beperken (\% bedrijven), 2007-2011

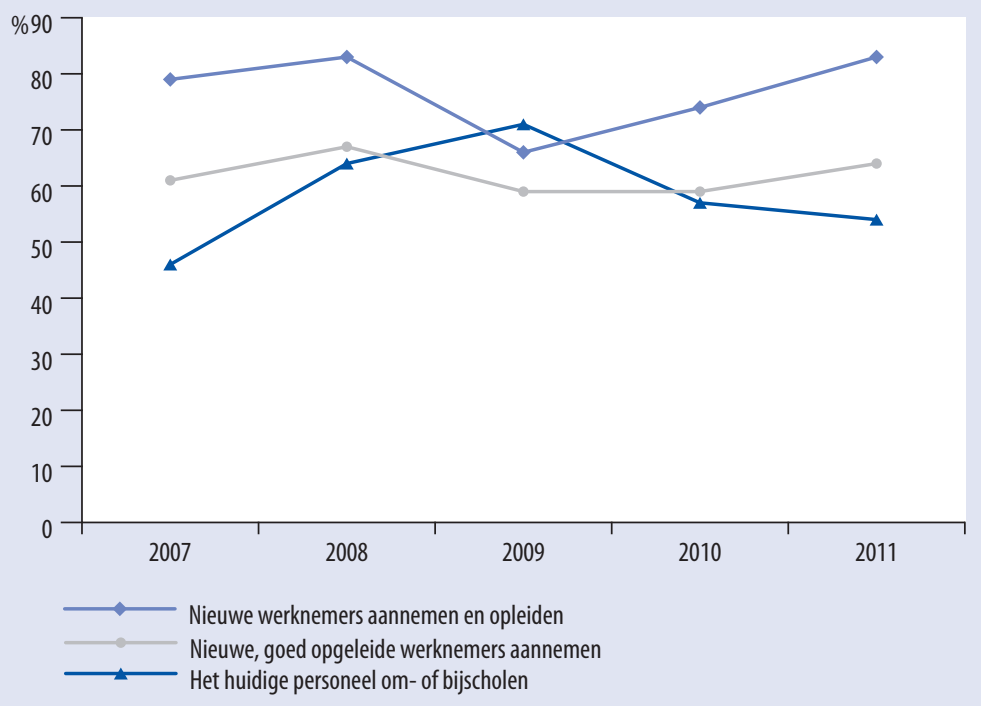

Bron: ROA, Arbeidsmarktmonitor Metalektro, 2007-2011

\subsection{Leeftijdsbewust personeelsbeleid}

Iets wat de laatste jaren in toenemende mate onderwerp van gesprek is, is de speciale aandacht voor specifieke groepen werknemers. Of er in dit kader nu gesproken wordt over maatregelen gericht op duurzame inzetbaarheid van personeel, leeftijdsbewust personeelsbeleid of levensfasebewust personeelsbeleid, alle hebben als gemeenschappelijk doel om medewerkers zo lang mogelijk op een productieve wijze inzetbaar te houden. Hierbij trachten bedrijven te voorkomen dat medewerkers vroegtijdig uitvallen of op een te laag niveau productief zijn.

Tijdens een internationaal seminar 'Learning later in life' van Cedefop, het Europees centrum voor de ontwikkeling van beroepsopleidingen, in september 2011 te Brussel was de duurzame inzetbaarheid van oudere medewerkers het centrale thema. Als het over oudere werknemers gaat, gaat het in de regel over werkzaamheden die zij niet meer optimaal zouden kunnen uitvoeren. Vaak wordt hierbij gewezen op hun afnemende fysieke gesteldheid, vaardigheden, flexibiliteit, innovatievermogen, bereidheid aan cursussen deel te nemen, of in het algemeen om in zichzelf te investeren. Daar staan bovendien meestal hoge salariskosten tegenover. Vaak wordt echter te gemakkelijk voorbijgegaan aan de positieve eigenschappen van oudere werknemers die hen juist aantrekkelijk kunnen maken voor werkgevers, zoals een goede arbeidsmoraal, kwaliteitsbewustheid, loyaliteit en waardevolle ervaring. 
Aan de bedrijven is gevraagd om aan te geven of zij bepaalde HRM-instrumenten aan jongere $(<45$ jaar) of juist aan oudere medewerkers (45-plussers) aanbieden. Figuur 6.5 laat zien dat metalektrobedrijven een drietal HRM-instrumenten vaak aanbiedt voor 45-plussers. Bedrijven laten 45-plussers vaker werkzaamheden verrichten waarbij kennis overgedragen wordt. Ook laten ze oudere medewerkers vaker (gedeeltelijk) andere werkzaamheden verrichten en minder uren werken. Het komt minder vaak voor dat het HRM-beleid specifiek op jongeren gericht is. Jongeren krijgen wel vaker dan ouderen opleidingsmogelijkheden en loopbaangesprekken. Deze mogelijkheden worden echter vaak ook aangeboden aan alle medewerkers.

\section{Figuur 6.5}

Inzet van HRM-instrumenten voor medewerkers die jonger of ouder zijn dan 45 jaar (\% bedrijven), 2011

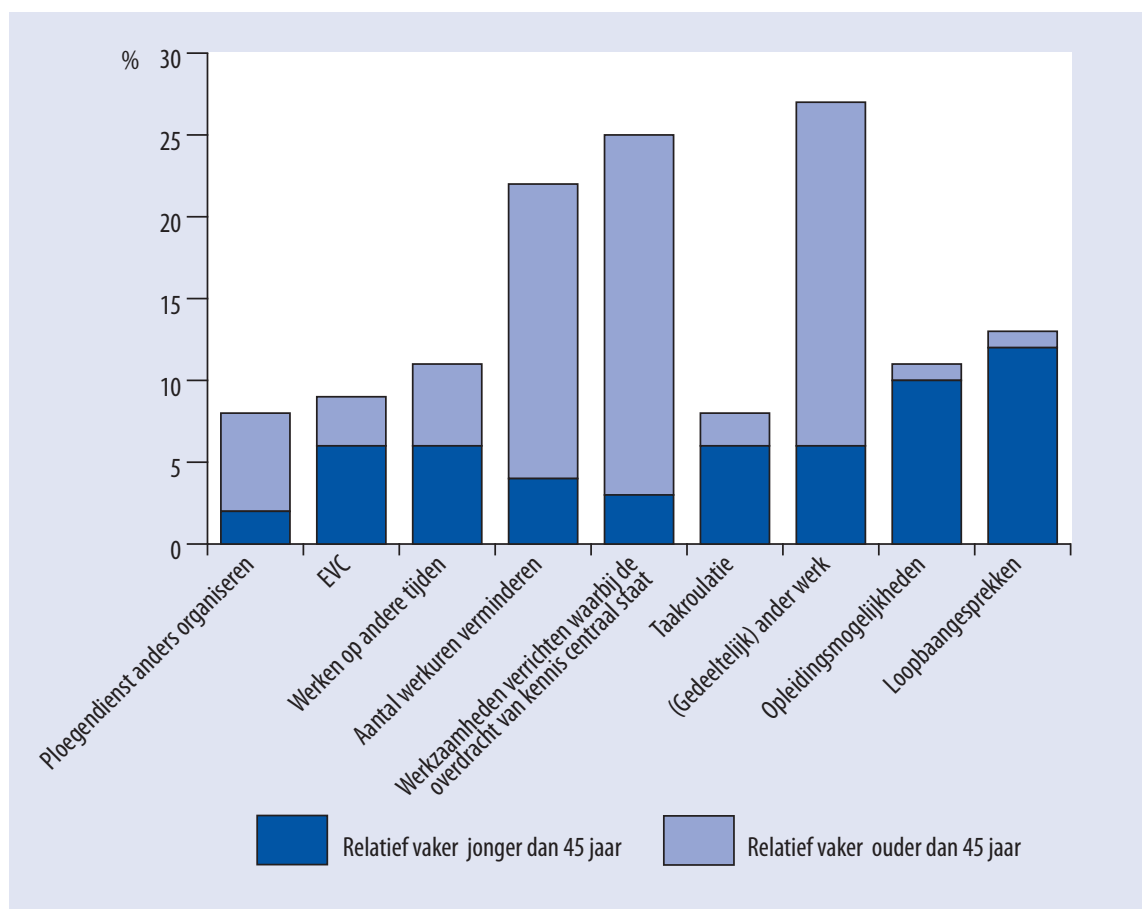

Bron: ROA, Arbeidsmarktmonitor Metalektro, 2011

\section{Duurzame inzetbaarheid: een praktisch voorbeeld}

Eén bedrijf gaf tijdens een interview aan dat er geen speciaal op oudere werknemers gericht beleid is, maar dat er wel maatregelen genomen zijn om de duurzame inzetbaarheid van alle medewerkers te bevorderen. Zo zijn er in het hele bedrijf werkplekanalyses gemaakt door een bedrijfsergonoom. Op deze manier kunnen personen die niet meer goed kunnen functioneren op een werkplek die voor hen te belastend is, gemakkelijker overgeplaatst worden naar een andere, beter passende werkplek. 


\section{Prognoses voor de Metalektro}

De uitdagingen in het personeelsbeleid van de Metalektro zijn vooral gelegen in de toenemende uitstroom van oudere werknemers die vervangen moeten worden. De afnemende instroom van schoolverlaters zal tekorten op de arbeidsmarkt van technisch opgeleide werknemers veroorzaken. De bedrijven zien voor de komende jaren wel een trend in het upgraden van hun personeel naar hogere opleidingsniveaus. Een duidelijke verschuiving richting werknemers met hoger middelbaar en hoger beroepsonderwijs ten koste van lager en lager middelbaar opgeleide werknemers wordt door bijna alle bedrijven verwacht. De vergrijzing zal ook de nodige veranderingen in het personeelsbeleid ten opzichte van de duurzame inzetbaarheid resulteren. Zo blijven de belangrijkste speerpunten voor de komende vijf jaar het werken aan de inzetbaarheid van het personeel en het terugdringen van verzuim. 


\subsection{Prognose arbeidsmarkt tot 2016}

Het ROA voorspelt voor de komende jaren flinke tekorten aan technisch opgeleiden. Bij veel technische functies zal het problemen opleveren om voldoende nieuwe medewerkers aan te kunnen trekken. In deze functies zal de vraag naar nieuwe medewerkers groot zijn. De vraag is niet zozeer groot omdat de werkgelegenheid voor deze functies sterk zal toenemen, maar vooral omdat de komende jaren veel oudere medewerkers met pensioen zullen gaan en vervangen moeten worden om het personeelsbestand op peil te kunnen houden.

De meest recente arbeidsmarktprognoses van het ROA voorspellen flinke tekorten aan technisch opgeleiden. ${ }^{2}$ Op alle opleidingsniveaus ontstaan meer baanopeningen dan dat er arbeidsmarktinstroom tegenover staat, waardoor in totaal een tekort van meer dan 150.000 technici verwacht wordt. De grootste tekorten worden volgens de prognoses van het ROA op de lagere en middelbare opleidingsniveaus verwacht, maar ook op hoger opleidingsniveau zullen er tekorten optreden.

\section{Figuur 7.1}

Arbeidsmarktprognose technische opleidingen, 2011-2016

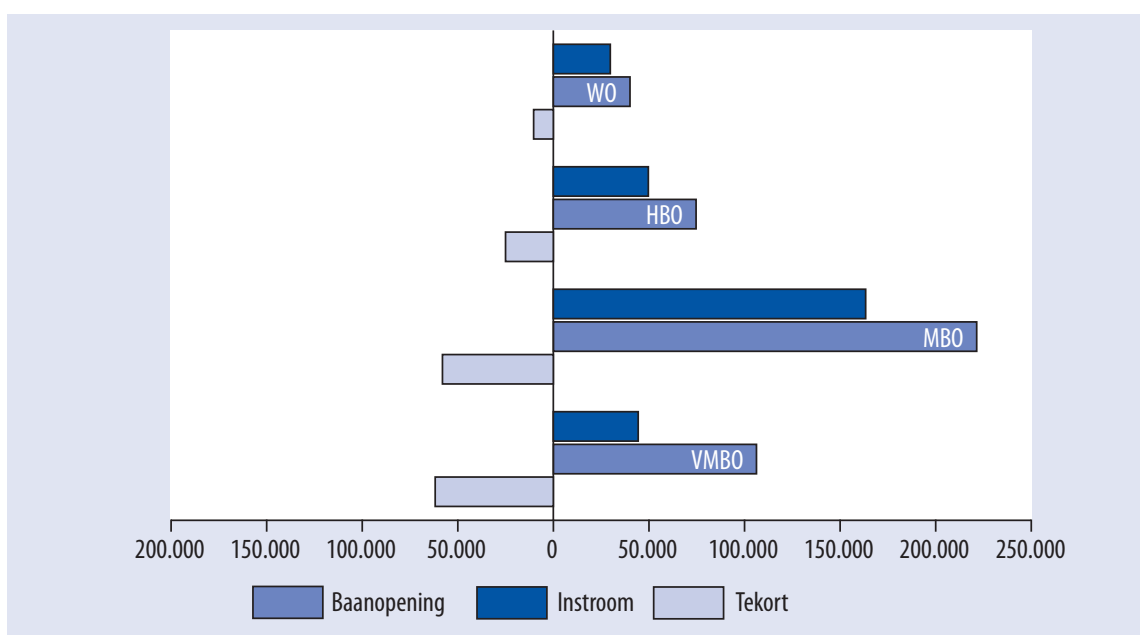

Noot: Tekorten zijn berekend als baanopening minus instroom.

Bron: ROA, Arbeidsmarkt naar opleiding en beroep tot 2016

Figuur 7.I geeft een overzicht van de baanopeningen voor de technische opleidingen op de verschillende niveaus in de periode 20II-20I6. Deze baanopeningen zijn een optelsom van de uitbreidingsvraag en de vervangingsvraag. De baanopeningen worden afgezet tegen de verwachte arbeidsmarktinstroom vanuit de opleidingen. De figuur laat duidelijk zien dat de instroom van technisch opgeleiden op alle niveaus

2. Bertrand-Cloodt, D., F. Cörvers, T. Dohmen, A. Dupuy, D. Fouarge, A. de Grip, B. Kriechel, A. Nelen \& J. van Thor (20II). De arbeidsmarkt naar opleiding en beroep tot 20I6. Maastricht: ROA-R-20II/8. 
tekort schiet om in de vraag te kunnen voorzien. Daarbij zijn de tekorten op vmboen mbo-niveau in absolute zin het grootst.

Meer specifieke prognoses van het ROA laten zien dat de knelpunten in de personeelsvoorziening vooral groot zullen zijn voor de opleidingen elektrotechniek op mbo- en hbo-niveau en werktuigbouwkunde op hbo- en wo-niveau. Overigens werken uiteraard niet alle technisch opgeleide werknemers in de industrie of in technische functies. Hoewel het gros van de technisch opgeleiden in technische functies werkzaam is, is er ook in andere sectoren en beroepen behoefte aan werknemers met een technische opleiding. Dit betekent dat metalektrobedrijven op de arbeidsmarkt ook concurrentie zullen ondervinden van andere bedrijfstakken. Daarom is het van groot belang dat de Metalektro een goed imago heeft onder de schoolverlaters van het technisch onderwijs.

Tabel 7.1

Prognose percentage technisch opgeleiden in totale arbeidsmarktinstroom, 2011-2016

\begin{tabular}{lccc|}
\hline Instroom & $\begin{array}{c}\text { Instroom } \\
\text { technische opleidingen }\end{array}$ & Technisch \\
\hline VMBO & 193.700 & 44.400 & $23 \%$ \\
MBO & 623.800 & 163.400 & $26 \%$ \\
\hline HBO & 328.500 & 49.700 & $15 \%$ \\
W0 & 183.500 & 29.800 & $16 \%$ \\
\hline Totaal & $\mathbf{1 . 3 2 9 . 5 0 0}$ & $\mathbf{2 8 7 . 3 0 0}$ & $\mathbf{2 2} \%$ \\
\hline
\end{tabular}

Bron: ROA, Arbeidsmarkt naar opleiding en beroep tot 2016

Het ROA maakt ook prognoses die zich richten op vraag en aanbod voor de technische functies. Deze prognoses laten zien dat er op de middellange termijn bij 75\% van deze functies sprake is van grote tot zeer grote knelpunten in de personeelsvoorziening. Daarbij zullen de personeelstekorten voor technisch analisten en werktuigbouwkundigen naar verwachting zeer groot zijn, maar ook voor metaalarbeiders, bankwerkers en lassers, assembleurs, monteurs, elektromonteurs en elektrotechnisch ontwerpers worden er grote tekorten verwacht. Om de toekomstige schaarste aan personeel in deze functies het hoofd te bieden zal de sector er hard aan moeten trekken om de arbeidsmarktinstroom uit de technische opleidingen op peil te houden of te vergroten door het werken in de Metalektro attractief te maken en te promoten. Op deze manier kan de sector er niet alleen voor zorgen dat meer technisch opgeleiden kiezen voor een baan in de Metalektro, maar kan deze er ook toe bijdragen dat meer jongeren kiezen voor een technische opleiding. Zoals tabel 7.I laat zien, zal volgens de prognoses de komende jaren slechts een kwart van de arbeidsmarktinstroom op vmbo- en mboniveau een technische opleiding gevolgd hebben, terwijl dit van de hoger opgeleiden slechts $15 \%$ zal zijn. Dit betekent dat er nog een flinke kloof is met de in het recent gepubliceerde 'Masterplan Bèta en Technologie' geformuleerde doelstelling dat $40 \%$ van de arbeidsmarktinstroom een technische opleidingsachtergrond moet hebben. ${ }^{3}$

3. Topsectoren Nederlandse Economie, Naar 4 op de io. Meer technologietalent voor Nederland, Den Haag, 20I2. 


\section{De belangstelling voor techniek: de invloed van de reisafstand}

Tijdens hun schooltijd leggen jongeren met belangstelling voor een functie in de techniek de basis voor hun technische kennis en vaardigheden. Al jaren wordt echter gesproken over het oplopende tekort aan jongeren die voor een opleiding in de techniek kiezen. De laatste is jaren er dan ook veel aandacht voor factoren die leerlingen wellicht kunnen overhalen om voor een technische opleiding te kiezen (bijvoorbeeld het verder verbeteren van het imago van de techniek). Veel minder aandacht is er doorgaans voor het negatieve effect van de afstand die leerlingen moeten afleggen naar school, op de keuze voor een opleiding techniek. Veel leerlingen staan bij hun schoolkeuze voor meerdere opties open. Dan is het niet verwonderlijk dat een leerling bij twijfel eerder voor bijvoorbeeld een opleiding economie zal kiezen, als hij of zij hiervoor minder ver hoeft te reizen. Hierdoor kunnen potentieel geïnteresseerden in de techniek voor het vak verloren gaan.

Recentelijk heeft het ROA onderzocht hoe afstandsgevoelig jongeren in het voortgezet onderwijs (vmbo/ havo) zijn bij de overgang naar het middelbaar beroepsonderwijs (mbo) en welke invloed de ruimtelijke spreiding van mbo-opleidingen over verschillende opleidingslocaties heeft op de keuze voor één van de sectoren techniek, economie of zorg. ${ }^{*}$ Uit het onderzoek blijkt dat de kans om voor een opleidingssector te kiezen significant afneemt, wanneer de afstand tot de dichtstbijzijnde opleidingslocatie waar deze sector wordt aangeboden groter is. Dit effect geldt ook voor de op één na dichtstbijzijnde locatie waar een opleidingssector wordt aangeboden. Uit het onderzoek blijkt dat de reisafstand bij de keuze voor een technische opleiding een belangrijke rol speelt. De kans dat een leerling voor techniek kiest neemt met $6 \%$ af als de dichtstbijzijnde locatie waar techniek wordt gegeven 20 kilometer verder weg ligt. Wanneer de reisafstand naar een techniekopleiding groter is, kiezen leerlingen bovendien significant vaker voor een opleiding economie. Techniekleerlingen blijken overigens minder afstandsgevoelig te zijn dan leerlingen die voor een andere sector kiezen. Zij kiezen waarschijnlijk vaker voor een technische studie vanwege een sterke intrinsieke motivatie. De resultaten laten zien dat een betere regionale spreiding van technische opleidingen er toe kan leiden dat meer leerlingen voor een techniekopleiding kiezen. De toenemende concentratie van opleidingen kan dus negatieve consequenties hebben voor de deelname van leerlingen aan technische opleidingen.

* Zie: D. Bertrand-Cloodt, F. Cörvers, H. Heijke \& J. van Thor (2011), Verkenning van de invloed van reisafstand op de keuze voor een middelbare beroepsopleiding, ROA, Maastricht.

De vervangingsvraag naar beroep is het resultaat van de leeftijdsopbouw van het personeel en de (netto) uitstroom uit de beroepen. De arbeidsmarktprognose van het ROA geeft hier geen direct uitsluitsel voor de Metalektro. Maar de leeftijdsopbouw van de sector is wel enigszins in te schatten aan de hand van de leeftijdsopbouw van deelnemers aan het pensioenfonds PME. Hieruit blijkt dat de gemiddelde leeftijd van werkenden geconcentreerd is rond de 40-plussers. Voor de vervangingsvraag van de komende jaren zijn met name de werknemers boven de 6o, en in mindere mate boven de 55, van belang. Deze zullen immers in de komende vijf of tien jaar met pensioen gaan. $4 \%$ van het personeelsbestand zal in de komende vijf jaar zeker vervangen moeten worden aangezien zij 60 jaar of ouder zijn, en nog eens I $2 \%$ bevindt zich in de leeftijdsgroep van 55-59 jaar (zie Figuur I.5). 


\subsection{Verwachtingen bedrijven 2012-2013}

De Arbeidsmarktmonitor Metalektro geeft op enkele punten een gedetailleerder beeld van de verwachtingen die de bedrijven hebben ten aanzien van de toekomstige ontwikkelingen op de voor hen relevante segmenten van de arbeidsmarkt. Voor 2012 en 2013 verwachten bedrijven een voortzetting van de min of meer trendmatige upgrading van het opleidingsniveau van hun personeel. De verschuiving vindt plaats van lbo en mbo niveau I-2 naar mbo niveau 3-4 en hoger opgeleid personeel. Dit is een ontwikkeling die zich in vrijwel alle sectoren van de Nederlandse economie voordoet.

Figuur 7.2 geeft een overzicht van de werkgelegenheidsverschuiving binnen de verschillende opleidingsniveaus. Ongeveer 30\% van de bedrijven verwacht een daling van de werkgelegenheid op lbo-niveau. Een kwart van de huidige werknemers heeft dit opleidingsniveau. Op mbo niveau I-2, dat bijna de helft van de werknemers omvat, verwacht een ongeveer vergelijkbaar deel van de bedrijven dat de werkgelegenheid zal toenemen als dat deze op dit niveau zal afnemen. Daar staat tegenover dat zowel op mbo niveau 3-4 als op hbo-niveau duidelijk een toename van de werkgelegenheid verwacht wordt. Voor beide opleidingsniveaus geldt dat ongeveer een derde van de bedrijven verwacht dat de werkgelegenheid zal toenemen, terwijl er vrijwel geen bedrijven zijn die verwachten dat de werkgelegenheid op deze niveaus zal krimpen. Op mbo niveau 3-4 wordt zelfs nog een iets grotere toename van de werkgelegenheid verwacht dan op hbo-niveau.

\section{Figuur 7.2}

Verwachte werkgelegenheidsontwikkeling naar opleidingsniveau (\% bedrijven) in 2012 en 2013

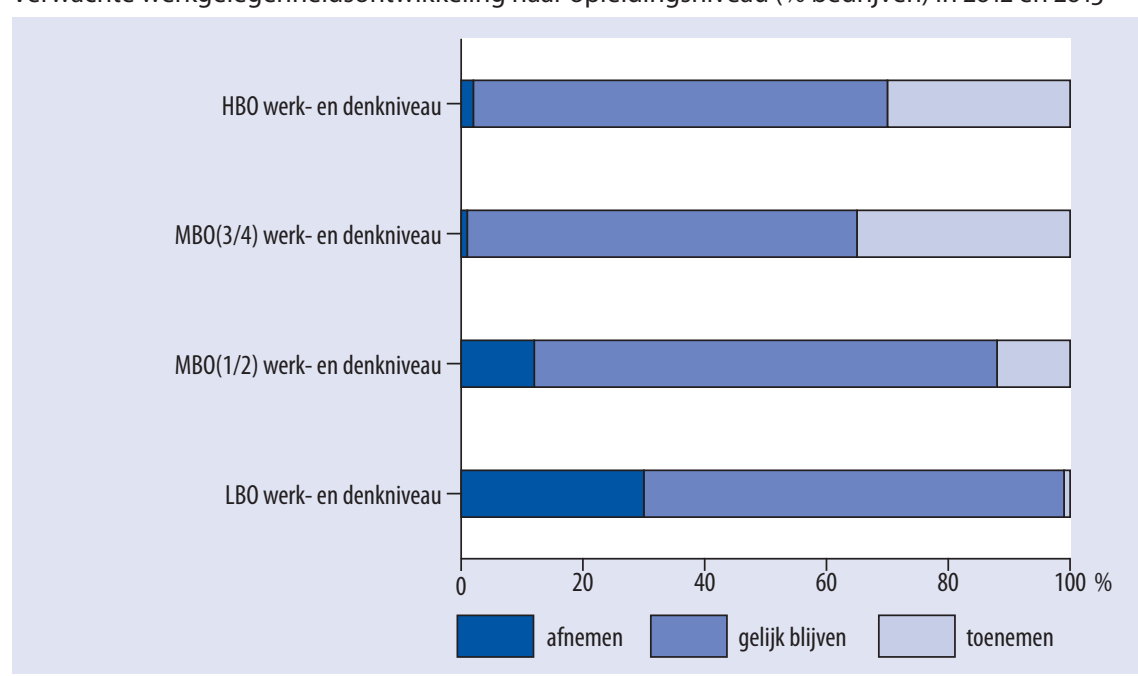

Bron: ROA, Arbeidsmarktmonitor Metalektro, 2011 


\subsection{Veranderingen personeel}

Zoals in hoofdstuk 4 en 5 reeds aan bod kwam, verwachten veel bedrijven dat de inhoud van functies in hun bedrijf zal veranderen vanwege vernieuwingen van zowel productieprocessen als de aard van de producten en diensten die bedrijven in de toekomst zullen produceren. Zo kan er bijvoorbeeld meer verantwoordelijkheid gedelegeerd worden naar medewerkers die werkzaam zijn op uitvoerend niveau, waar werknemers, al dan niet in teamverband, verantwoordelijk zijn voor het productieproces, het initiële oplossen van problemen en ook het verbeteren en stroomlijnen van productieprocessen. Deze toenemende verantwoordelijkheid vereist wel een bepaald scholings- en denkniveau. Werknemers moeten probleemoplossend kunnen denken, ze moeten enig inzicht in het proces hebben, maar ook aanvoelen wanneer er externe expertise ingeschakeld moet worden. Andere werknemers kunnen naast hun rol in het productie- of ontwikkelingsproces, ook in toenemende mate worden ingezet bij de directe klantcontacten. Beide ontwikkelingen vereisen dat het (uitvoerend) technisch personeel in metalektrobedrijven in toenemende mate beschikt over soft skills, zoals deze in de PROFI-agenda geformuleerd worden (zie hoofdstuk 8).

Een toenemende specialisatie is vooral vereist bij de ontwikkeling van nieuwe producten, maar ook in het productieproces zelf, waar bedrijven zich steeds vaker toeleggen op bepaalde elementen van het product of slechts specifieke fases van het productieproces. Deze toenemende specialisatie stimuleert het innovatieproces binnen bedrijven, maar verhoogt vaak ook de efficiency van het productieproces. Beide ontwikkelingen zijn van cruciaal belang voor de levensvatbaarheid van bedrijven in de Metalektro. Dit temeer daar Nederland geen land is dat internationaal gezien op basis van loonkosten kan concurreren.

Deze ontwikkelingen komen duidelijk tot uiting in de verwachtingen van bedrijven over de ontwikkeling van de inhoud van de functies in de komende vijf jaar (zie Figuur 7.3). Evenals vorig jaar verwacht meer dan twee derde van de bedrijven voor de jaren 20I2-20I6 een toenemend belang van gedragsmatige competenties. Inmiddels verwacht meer dan de helft van de bedrijven dat de verantwoordelijkheid voor medewerkers die werkzaam zijn in de lagere functies binnen de organisatie zal toenemen. Ook zien we dat de tendens dat technische functies meer 'allround' worden doorzet. Daarentegen neemt het percentage bedrijven dat verwacht dat technische functies specialistischer worden weer af. Dit suggereert dat de behoefte aan allround inzetbare medewerkers in een toenemend aantal bedrijven de dominante trend wordt. 


\section{Figuur 7.3}

Verwachte veranderingen in de functies van het technisch personeel in de komende 5 jaar (\% bedrijven)

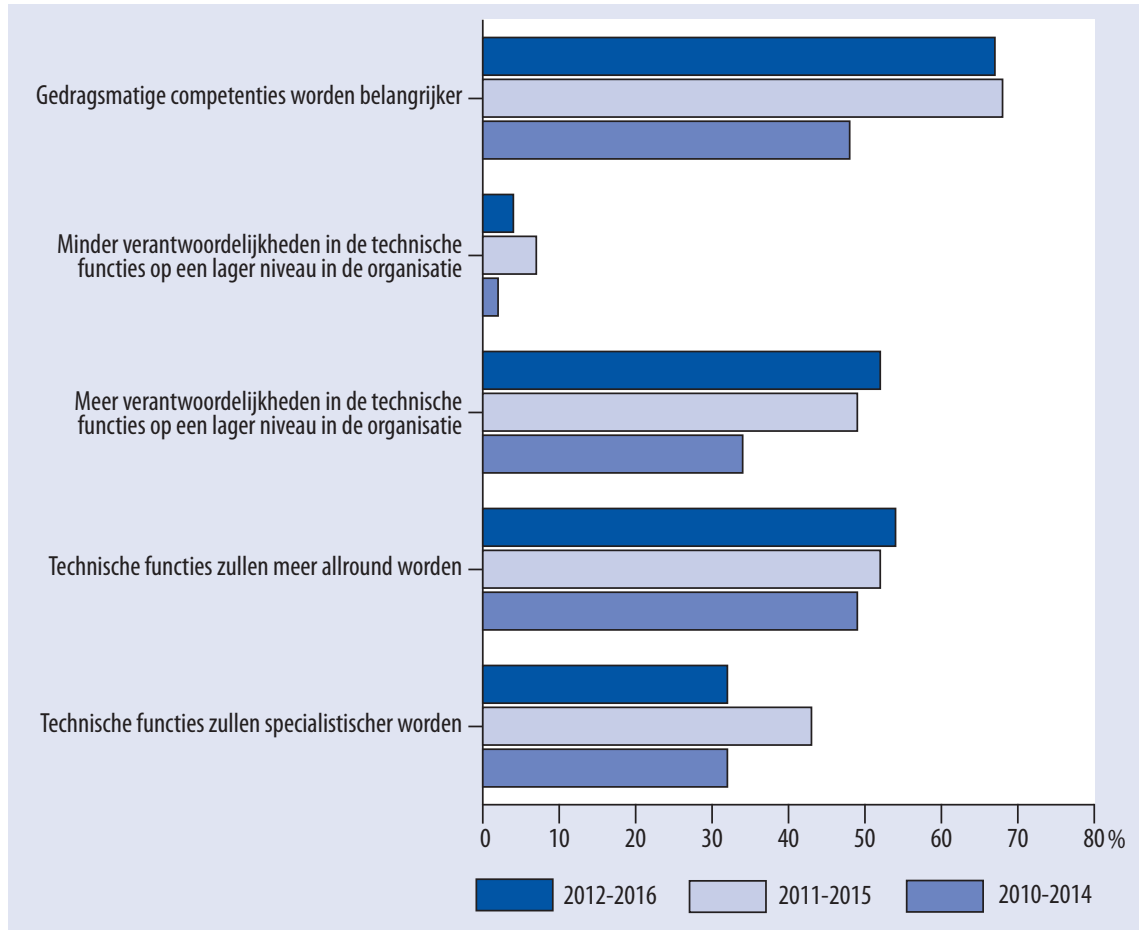

Bron: ROA, Arbeidsmarktmonitor Metalektro, 2009-2011

\subsection{Speerpunten personeelsbeleid 2012-2016}

Veel bedrijven formuleren speerpunten voor hun toekomstig personeelsbeleid. Deze speerpunten helpen bedrijven om hun personeelsbeleid proactief af te stemmen op de verwachte veranderingen op het gebied van het aanbod van personeel, de productieprocessen en organisatiestructuur, en de werkomstandigheden. Overigens kunnen de speerpunten van het personeelsbeleid ook als doel hebben om adequaat in te spelen op de huidige problemen die zich binnen het bedrijf voordoen.

Zoals figuur 7.4 laat zien, verdienen twee speerpunten voor veel bedrijven in de Metalektro bijzondere aandacht. Zo noemt het overgrote deel van de bedrijven het bevorderen van de inzetbaarheid van het personeel als speerpunt van het personeelsbeleid in de periode 20I2-20I6. Bijna twee derde van de bedrijven heeft dit als speerpunt geformuleerd en hoopt zo de capaciteiten van het personeel op peil te houden of te verbeteren ten behoeve van toekomstige productieprocessen. Daarnaast is ook het verminderen van het verzuim voor ruim $40 \%$ van de bedrijven een belangrijk speer- 
punt. Het belang van beide speerpunten is duidelijk toegenomen ten opzichte van de meting in 20IO, toen gevraagd werd naar de belangrijkste speerpunten van het personeelsbeleid voor de jaren 20II-20I5. Daarmee is het percentage metalektrobedrijven met deze speerpunten weer terug op het niveau van voor de economische crisis.

Figuur 7.4

Toekomstige speerpunten personeelsbeleid (\% bedrijven)

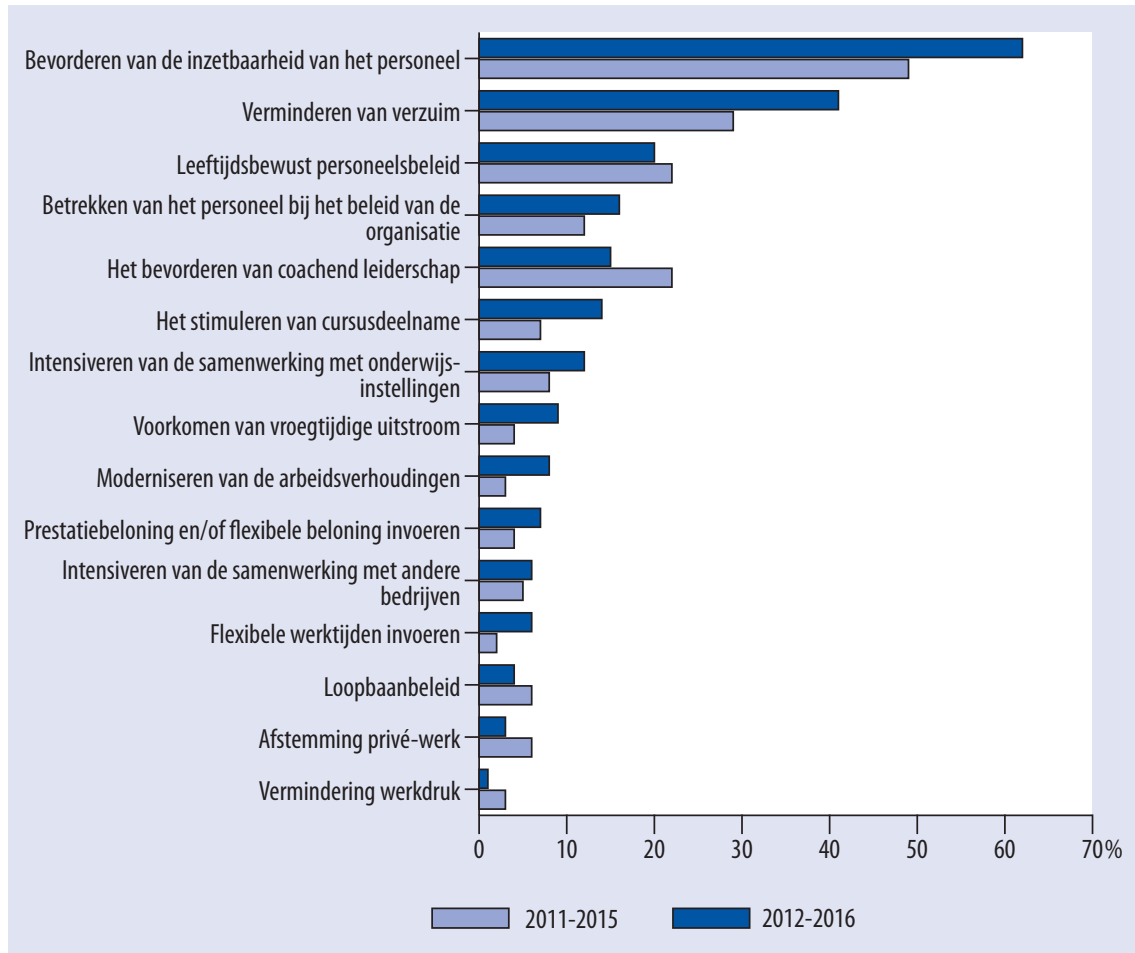

Bron: ROA, Arbeidsmarktmonitor Metalektro, 2010-2011

Een belangrijk speerpunt dat gericht is op het op peil houden of verbeteren van de duurzame inzetbaarheid van het vergrijzende personeelsbestand is het voeren van een leeftijdsbewust personeelsbeleid (zie ook hoofdstuk 6). Hoewel de noodzaak van leeftijdsbewust personeelsbeleid meer en meer onderkend wordt, geeft nog steeds slechts $20 \%$ van de bedrijven aan dat dit een speerpunt van het personeelsbeleid is. Dit speerpunt verdient duidelijk meer aandacht gezien de dreigende toekomstige tekorten aan technici op de arbeidsmarkt en de toenemende vergrijzing van het personeelsbestand. Bovendien wordt van deze groep ook nog eens verwacht dat zij langer blijven doorwerken dan de medewerkers die de afgelopen jaren met pensioen zijn gegaan. 
Om de geformuleerde speerpunten daadwerkelijk te kunnen verwezenlijken kunnen er verschillende specifieke HRM-instrumenten worden ingezet (figuur 7.5). Afhankelijk van de gekozen speerpunten moet bekeken worden welke instrumenten het meest effectief zijn. De komende vijf jaar zal meer dan $60 \%$ van de bedrijven één of meer van deze speerpunten in het personeelsbeleid aankaarten tijdens functioneringsgesprekken met werknemers. Functioneringsgesprekken bieden dan ook een uitgelezen mogelijkheid om de speerpunten van het personeelsbeleid onder de aandacht te brengen. Andere veelgebruikte HRM-instrumenten waarmee bedrijven bepaalde speerpunten willen realiseren zijn het voeren van beoordelingsgesprekken en werkoverleggen. Bij de helft van de bedrijven worden deze gesprekken vanuit dit oogpunt gevoerd. Bovendien kiest een aanzienlijk deel van de bedrijven ervoor om de speerpunten aan de orde te stellen tijdens een scholings- of ontwikkelingsgesprek en persoonlijk ontwikkelingsplan (POP). Het gebruik van deze gesprekken is complementair. Zo voeren bedrijven die POP's inzetten bijvoorbeeld ook vaker scholingsgesprekken. Werkoverleggen komen vaak voor in bedrijven die afspraken vastleggen in bijvoorbeeld POP's of BOP's. Scholings- en ontwikkelingsinstrumenten gaan vaak gepaard met opleidingsinstrumenten zoals opleidingsbudgetten (persoonlijk en/of op bedrijfsniveau).

Figuur 7.5

HRM-instrumenten ten behoeve van het bereiken van toekomstige speerpunten (\% bedrijven), 2010-2011

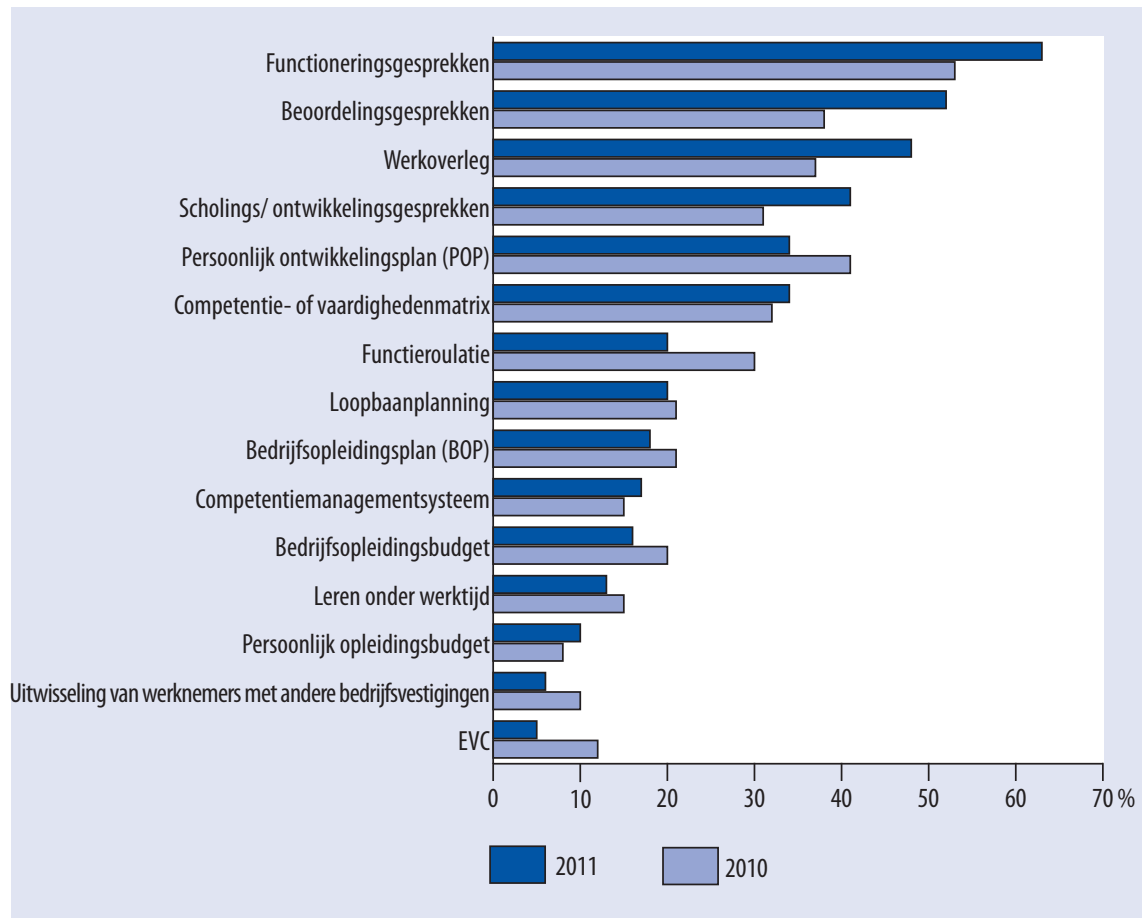

Bron: ROA, Arbeidsmarktmonitor Metalektro, 2010-2011 
Daarbij is het opvallend dat in vergelijking met vorig jaar het percentage bedrijven waarvoor werkoverleggen en scholings- of ontwikkelingsgesprekken met medewerkers worden ingezet om de speerpunten van hun personeelsbeleid te realiseren is toegenomen. Daarentegen denken veel minder bedrijven gebruik te gaan maken van POP's en functieroulatie. Vooral dat laatste lijkt tegenstrijdig met het feit dat bedrijven het bevorderen van de inzetbaarheid van personeel het vaakst als belangrijk speerpunt van hun personeelsbeleid noemen.

In vergelijking met vorig jaar verwachten duidelijk minder bedrijven problemen bij het realiseren van hun speerpunten (zie Figuur 7.6). Het percentage bedrijven dat geen problemen verwacht steeg van $25 \%$ tot $36 \%$. Dat wil zeggen dat meer dan een derde van de bedrijven geen of nauwelijks problemen verwacht bij het realiseren van de speerpunten van hun personeelsbeleid. De bedrijven die wel problemen verwachten, zien vooral problemen met de inzetbaarheid van het personeel dat zij momenteel in dienst hebben. Zij verwachten dat hun personeel moeilijk om kan gaan met veranderingen $(33 \%)$, een te laag kennisniveau heeft om de speerpunten zonder problemen te realiseren $(24 \%)$, of niet flexibel genoeg is $(20 \%)$. Daarnaast wordt ook getwijfeld aan de motivatie van het personeel om met veranderingen om te gaan, of de bereidheid van medewerkers om in zichzelf te investeren. Het valt op dat met name het percentage bedrijven dat verwacht dat medewerkers een te laag kennisniveau hebben en onvoldoende bereid zijn om in zichzelf te investeren is toegenomen.

\section{Figuur 7.6}

Verwachte knelpunten bij het realiseren van toekomstige speerpunten (\% bedrijven)

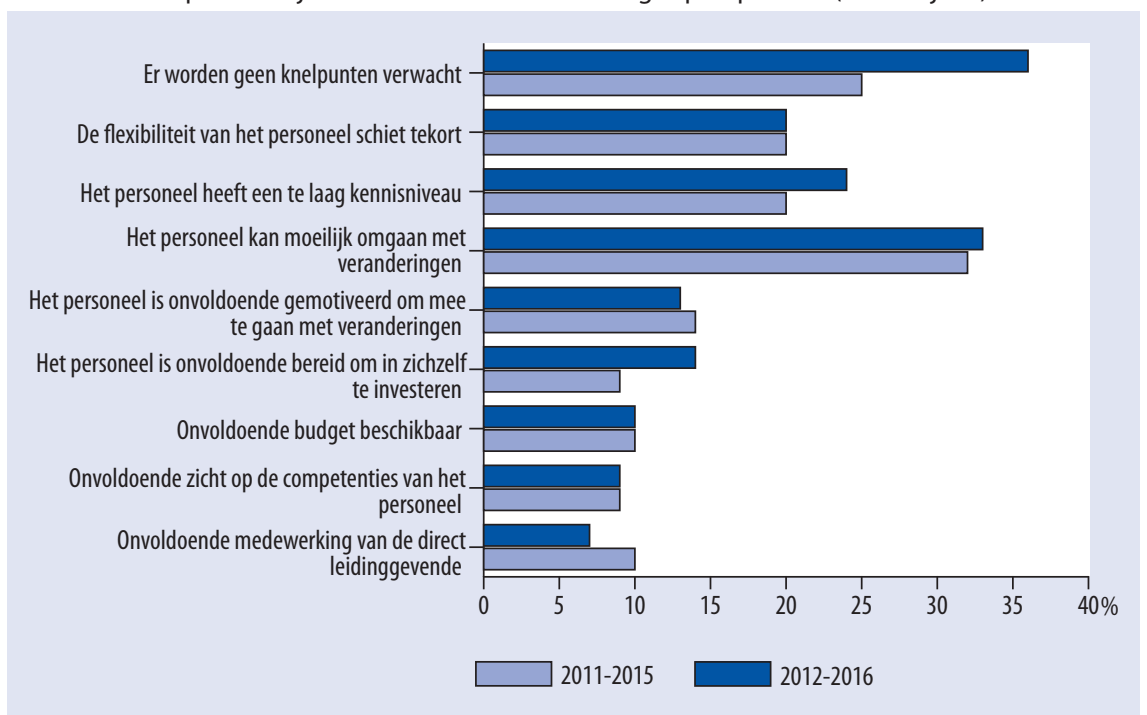

Bron: ROA, Arbeidsmarktmonitor Metalektro, 2010-2011 
Daarentegen zijn er maar weinig bedrijven die tekortkomingen op organisatieniveau verwachten, zoals onvoldoende financiële middelen, onvoldoende medewerking van de direct leidinggevenden of onvoldoende zicht op de competenties van personeel. In het algemeen zijn dit vergelijkbare percentages als in de recente crisisjaren, met uitzondering van het ontoereikend zijn van de financiële middelen. Terwijl dit in 20 o nog door een kwart van de bedrijven als een knelpunt werd gezien, ervaart nu nog maar $I$ \% dit als een mogelijk knelpunt. 



\section{Agenda voor de Toekomst: Human capital strategie}

In dit hoofdstuk worden de contouren aangegeven van de Agenda voor de Toekomst voor het human capital beleid in de Nederlandse Metalektrosector. Deze agenda biedt metalektrobedrijven handreikingen om de komende jaren de effectiviteit van hun human capital beleid te vergroten. Daarbij wordt ingegaan op de belangrijkste pijlers die deze human capital strategie moet hebben om de concurrentiekracht van de sector op zowel de afzetmarkt als de arbeidsmarkt te versterken. Bedrijven zullen hun human capital strategie moeten baseren op hun lange-termijn personeelsbehoefte en daarbij de voor het bedrijf optimale combinatie van "koop-en maakstrategieën" moeten formuleren om in hun toekomstige human capital behoefte te kunnen worden voorzien. Zowel de koop-als maakstrategieën hebben verschillende pijlers die elkaar kunnen versterken. Het wervings-en personeelsontwikkelingsbeleid vormen de belangrijkste pijlers, maar in aanvulling op dit HRM-beleid is het belangrijk om de human capital strategie te verbreden tot de organisaties waarmee wordt samengewerkt: onderwijsinstellingen, toeleveranciers, andere bedrijven in de regio, de flexibele schil, e.d. Om adequaat invulling te kunnen geven aan hun human capital strategie zullen bedrijven door middel van sociale innovatie hun HRM-beleid en externe samenwerking moeten versterken. 


\subsection{Human capital: "koop-" en "maakstrategieën"}

Zoals de monitor laat zien staan veel metalektrobedrijven voor belangrijke technologische uitdagingen die alleen gerealiseerd kunnen worden als bedrijven kunnen beschikken over het human capital dat hun concurrentiekracht versterkt. Maar wat betekenen de in de voorgaande hoofdstukken in kaart gebrachte ontwikkelingen in de Metalektro voor het beleid dat de bedrijven de komende jaren moeten gaan voeren? Gezien de te verwachten toename van de tekorten aan goed opgeleide technische vakkrachten op de Nederlandse arbeidsmarkt en de meer specifieke competentietekorten (zie hoofdstuk 7), zullen bedrijven veel aandacht moeten besteden aan hun human capital strategie.

Vanuit dit perspectief willen we in dit hoofdstuk de Agenda voor de Toekomst voor de Metalektro schetsen. Door te spreken van een integrale human capital strategie verbreden we de focus op het versterken van het HRM-beleid van de organisatie (wervingsbeleid, personeelsontwikkelingsbeleid, e.d.) met het versterken van de externe samenwerking waarmee het bedrijf voorziet in haar behoefte aan human capital. Hierbij kan onder meer gedacht worden aan samenwerking met onderwijsinstellingen, toeleveranciers, andere bedrijven in de regio en de flexibele schil.

Daarbij is het belangrijk om er oog voor te hebben dat een goede human capital strategie niet alleen cruciaal is voor het versterken van de concurrentiekracht op de afzetmarkten van het bedrijf, maar ook zeer bepalend zal zijn voor de aantrekkingskracht die het bedrijf heeft op de arbeidsmarkt. Daarbij gaat het zowel om het belang van de maakindustrie als geheel om te kunnen beschikken over voldoende goed inzetbare technici, als om de aantrekkingskracht die een specifiek bedrijf heeft op de mensen die het graag zou willen aantrekken.

Een integrale human capital strategie maakt het ook mogelijk om oog te hebben voor de verschillende manieren waarop een bedrijf aan het benodigde human capital kan komen. Daarbij kan een onderscheid worden gemaakt tussen een koop- en een maakstrategie. Figuur 8.I brengt dit speelveld voor het human capital beleid in beeld. De verticale as geeft aan in hoeverre een bedrijf een beroep doet op extern human capital, terwijl de horizontale as aangeeft in hoeverre een bedrijf zelf human capital ontwikkelt. Bedrijven kunnen op deze wijze worden ingedeeld in vier categorieën:

- Bedrijven met een low-skill strategie (linksonder).

- Bedrijven met een koopstrategie (linksboven).

- Bedrijven met een maakstrategie (rechtsonder).

- Bedrijven met een human capital accumulatie strategie (rechtsboven). 


\section{Figuur 8.1}

Human Capital (HC) strategie vereist combinatie koop en maak strategie

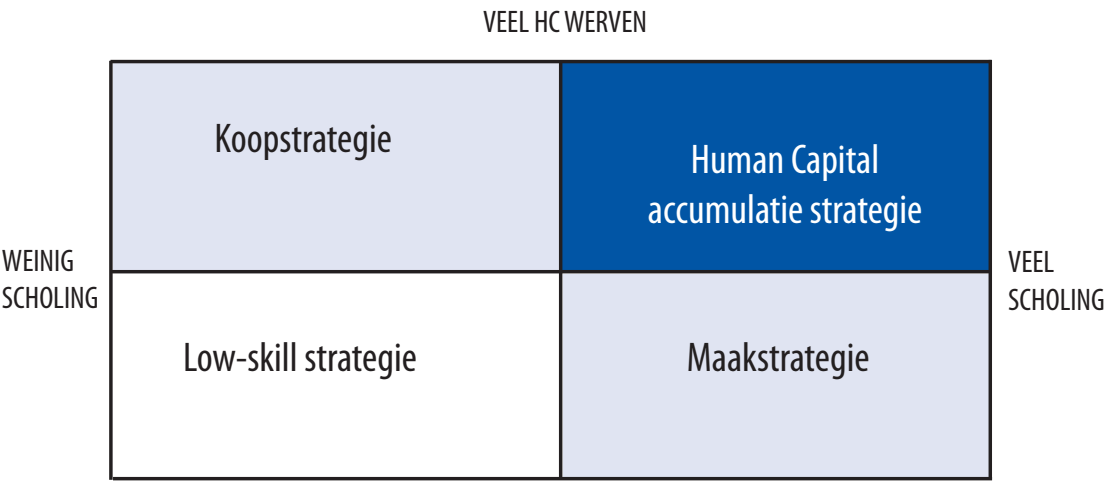

WEINIG HC WERVEN

Bedrijven met een low-skill strategie maken in het algemeen weinig gebruik van human capital. Het personeel dat ze aantrekken is betrekkelijk laag opgeleid en er wordt ook weinig aandacht besteed aan de verdere scholing en ontwikkeling van hun personeel. Zoals figuur 7.2 laat zien is het aantal lager opgeleiden waaraan metalektrobedrijven behoefte hebben in $201 \mathrm{I}$ weer verder afgenomen. Er zullen in Nederland in de Metalektro dan ook niet veel bedrijven meer zijn die nog een dergelijke low-skill strategie hebben. Dergelijke bedrijven zijn immers bij voorkeur gevestigd in lageloonlanden.

Bedrijven met een koopstrategie proberen in hun human capital behoefte te voorzien door goed opgeleide technici aan te trekken die voldoende werkervaring hebben opgedaan in andere bedrijven, of door gespecialiseerde vakmensen aan te trekken via een detacheringsbureau. Deze bedrijven besteden weinig middelen aan het op peil houden en verder ontwikkelen van de kennis en vaardigheden van hun medewerkers. Ook deze groep bedrijven is in de Metalektro betrekkelijk klein. Zo besteedt slechts $4 \%$ van de bedrijven geen middelen aan de scholing van de eigen medewerkers.

Bedrijven met een maakstrategie proberen in hun human capital behoefte te voorzien door veel te investeren in de verdere ontwikkeling van hun personeel. De Metalektro heeft op dit punt een lange traditie door als leerwerkbedrijf te fungeren voor de BBL-opleidingen en daarnaast ook veel te investeren in de scholing van hun personeel en het informele "learning by doing" op de werkvloer. Deze maakstrategie gaat over in een human capital accumulatie strategie als bedrijven (I) meer hoger opgeleide technici gaan werven, maar ook (2) meer aandacht gaan besteden aan het versterken van de kennis en vaardigheden bij hun partners in de keten en (3) door regionale samenwerkingsverbanden proberen het aanbod van goed inzetbare vakkrachten te vergroten. 


\subsection{Agenda voor de Toekomst}

In deze paragraaf gaan we in op de belangrijkste pijlers die de human capital strategie van de metalektrobedrijven moet hebben om hun concurrentiekracht op zowel de afzetmarkt als de arbeidsmarkt te versterken. Deze Agenda voor de Toekomst bouwt vanzelfsprekend voort op de in de vorige edities van de Arbeidsmarktmonitor geformuleerde aandachtspunten, maar deze zullen ditmaal expliciet in het bredere kader van een human capital strategie worden geplaatst. Daarmee biedt de Agenda voor de Toekomst metalektrobedrijven handreikingen om de komende jaren de effectiviteit van hun human capital beleid te vergroten.

Figuur 8.2

Agenda voor de toekomst: Human Capital strategie Metalektro

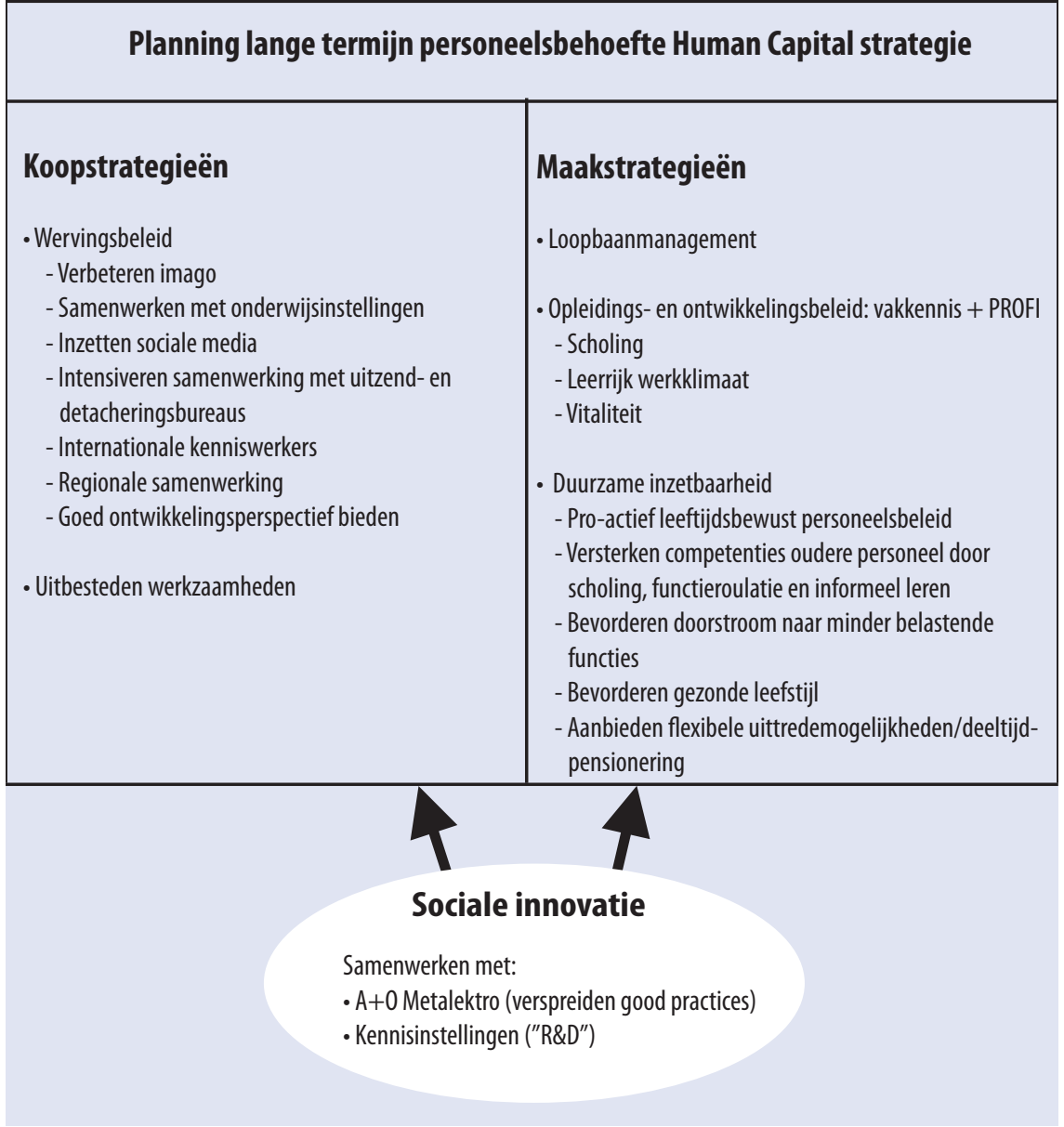


Figuur 8.2 schetst de contouren van de Agenda voor de Toekomst. Vertrekpunt voor een adequate human capital strategie is het in kaart brengen van de lange-termijn personeelsbehoefte. De visie op de lange-termijn personeelsbehoefte van het bedrijf biedt de basis voor het formuleren van een human capital strategie die de voor het bedrijf optimale combinatie van koop-en maakstrategieën aangeeft. Het schema schetst de belangrijkste pijlers van deze koop-en maakstrategieën. Daarbij staat het HRM-beleid van de bedrijven vanzelfsprekend centraal, maar in aanvulling daarop worden ook de pijlers van de externe human captial strategie aangegeven. Zoals het schema laat zien vormt sociale innovatie de motor voor het ontwikkelen van een adequaat human capital beleid, waarmee metalektrobedrijven zowel hun eigen HRM-beleid als de externe samenwerking kunnen versterken. Dit geldt zowel voor de pijlers van de maak-als voor de pijlers van de koopstrategie. Hieronder worden de pijlers van de Agenda voor de Toekomst verder uitgewerkt.

\section{Lange-termijn visie op personeelsbehoefte}

Bedrijven zouden hun human capital beleid moeten baseren op hun lange-termijnpersoneelsbehoefte. Startpunt van deze strategie is het zo goed mogelijk in kaart brengen van de verwachte personeelsbehoefte in de komende jaren en de op grond daarvan te verwachten kwantitatieve en kwalitatieve knelpunten. Zoals in hoofdstuk 7 werd aangegeven kunnen metalektrobedrijven verwachten dat ze de komende jaren geconfronteerd zullen worden met toenemende problemen om in hun personeelsbehoefte te kunnen voorzien. Daarom is het belangrijk dat bedrijven een goed beeld krijgen van:

- hun voor de komende jaren te verwachten vervangingsbehoefte vanwege de uitstroom van oudere medewerkers die met pensioen gaan en medewerkers die elders gaan werken;

- de eventuele groei of krimp van de gewenste personeelsomvang.

Dat laatste zal vaak slechts met een flinke bandbreedte kunnen worden aangegeven, maar voor de meeste bedrijven zal het aantal toekomstige vacatures voor het overgrote deel het gevolg zullen zijn van de personeelsuitstroom, die veel beter te voorspellen is. Daarnaast zullen bedrijven zich een beeld moeten vormen van de verwachte verschuivingen in de competenties waarover medewerkers moeten beschikken. Zoals hoofdstuk 4 liet zien zijn veel bedrijven zich er van bewust dat er naast toenemende vaktechnische kennis en vaardigheden ook een groeiende behoefte is aan gedragscompetenties (zie hieronder). Een hoge uitstroom van personeel dat met pensioen gaat kan er overigens ook toe leiden dat een deel van de opgebouwde expertise en bedrijfsspecifieke kennis verloren gaat als deze niet tijdig wordt overgedragen op de jongere medewerkers.

De visie die bedrijven hebben op hun lange-termijn personeelsbehoefte moet de basis vormen voor het formuleren van een human capital strategie, waarin de voor het 
bedrijf optimale combinatie van koop- en maakstrategieën moet worden geformuleerd om in hun toekomstige human capital behoefte te kunnen voorzien.

\section{Koopstrategieën}

\section{Wervingsbeleid}

De krapper wordende arbeidsmarkt voor technisch opgeleiden betekent dat metalektrobedrijven hun wervingskracht op de arbeidsmarkt moeten vergroten. Daarbij zal er veel aandacht moeten zijn voor het verbeteren van het imago van het werken in de Metalektro in het algemeen, alsook voor het vergroten van de aantrekkingskracht die het bedrijf heeft op mensen die voor een studie- of beroepskeuze staan en mensen die elders werkzaam zijn. De aantrekkingskracht van het bedrijf op de arbeidsmarkt wordt overigens in belangrijke mate ook bepaald door de ontwikkelingsmogelijkheden die het bedrijf nieuwe medewerkers biedt. Dit geeft aan dat het vrijwel onmogelijk is om in de personeelsbehoefte te voorzien op basis van alleen een koopstrategie. Een goed wervingsbeleid zal zich in de Metalektro met name moeten richten op:

- Het verbeteren van het imago van de techniek in het algemeen.

- Het verder ontwikkelen van nauwere en innovatieve manieren van samenwerking met het onderwijsveld.

- Het beter gebruik maken van de mogelijkheden die sociale media bieden om, in samenwerking met het huidige personeel, nieuwe medewerkers aan te trekken.

- Het optimaal gebruik maken van de mogelijkheden om via uitzendorganisaties of detacheringsbureaus nieuwe medewerkers te werven die tot de vaste kern van het bedrijf kunnen gaan behoren.

- Het vergroten van de wervingskracht van de Metalektro onder buitenlandse kenniswerkers die in Nederland een opleiding volgen, of interesse hebben om hier te komen werken.

- Regionale samenwerking met andere bedrijven om bij fluctuaties in de afzet personeel uit te wisselen.

- Het bieden van een aantrekkelijk ontwikkelings- en loopbaanperspectief aan nieuwe medewerkers.

\section{Uitbesteding van werkzaamheden}

Bedrijven kunnen ook in hun human capital behoefte voorzien door bepaalde werkzaamheden uit te besteden aan andere bedrijven. Zoals hoofdstuk 5 liet zien is vooral het uitbesteden van bepaalde onderdelen van het productiebedrijf naar andere bedrijven binnen Nederland steeds belangrijker aan het worden. Dit illustreert de toenemende samenwerking "in de keten", die in steeds sterkere mate gestuurd wordt door de strategie van het bedrijf om zich te richten op bepaalde kerncompetenties. Dit illustreert de complementariteit tussen de koop-en maakstrategie met betrekking tot het human capital waarover een bedrijf wil beschikken. Bij een krapper wordende 
arbeidsmarkt zal het uitbesteden van werkzaamheden waarvoor gespecialiseerde vakmensen nodig zijn, waarschijnlijk enig soelaas kunnen bieden.

\section{Maakstrategieën}

\section{Loopbaanmanagement}

Het HRM-beleid van metalektrobedrijven zal meer aandacht moeten besteden aan het verhogen van de interne mobiliteit, niet alleen vanwege de innovatiedynamiek en de behoefte aan flexibel, breed inzetbaar personeel, maar ook om het personeel aantrekkelijke loopbanen te kunnen bieden en ongewenst verloop te voorkomen. Daarbij kan coachend leiderschap de loopbaanperspectieven van het personeel versterken. Door het creëren van functies waarin werknemers verschillende aan elkaar gerelateerde taken vanuit een eigen verantwoordelijkheid uitvoeren, ontstaat hoogwaardige werkgelegenheid die medewerkers boeit en bindt. Dit vergroot de aantrekkingskracht van de sector op de arbeidsmarkt.

\section{Opleidings- en ontwikkelingsbeleid}

Voor een goed opleidings- en ontwikkelingsbeleid is het belangrijk dat het bedrijf een goed beeld heeft van de competenties van haar medewerkers. Ook is het belangrijk om een goede inschatting te kunnen maken van het verwachte competentieniveau van de beoogde instroom van toekomstige werknemers. De informatie over de competenties waarover het personeel bezit moet worden afgezet tegen de verwachte verschuivingen in de competenties waarover medewerkers de komende jaren zullen moeten beschikken. Deze informatie vormt de basis voor het formuleren van een opleidings- en ontwikkelingsbeleid dat is toegespitst op de bedrijfsspecifieke behoefte.

De meeste scholing die er in de Metalektro plaatsvindt is nog steeds gericht op het up-to-date houden van de technische vakkennis en vaardigheden voor de functie die medewerkers op dat moment uitoefenen. Daarbij speelt het opleidingsbeleid van metalektrobedrijven in op de upgrading van de vereiste competenties en de toenemende vraag naar allround vakmensen, die verantwoordelijkheid kunnen dragen voor de invulling van hun eigen werkzaamheden. Werknemers moeten voorbereid worden op toekomstige technologische vernieuwingen van het productieproces en sociale innovaties in de organisatie van het productieproces. Deze sociale innovaties zullen vaak betrekking hebben op het variabel inzetten van technici, projectmatig werken en het samenwerken met andere bedrijven. Dit vereist een toenemende aandacht voor de vijf essentiële gedragsmatige competenties, die we kunnen aanduiden als de PROFIagenda:

- Probleemoplossend vermogen

- Relatie met klanten

- Omgaan met veranderingen

- Flexibiliteit

- Initiatief 
Metalektrobedrijven moeten daarom in hun opleidings- en ontwikkelingsbeleid veel aandacht schenken aan het versterken van de PROFI-competenties van hun technisch personeel. Dit kan zowel door formele scholing als ook door gestructureerd gebruik te maken van informeel leren op de werkvloer. De effectiviteit van dit informeel leren kan versterkt worden door coachend leiderschap, waarbij de medewerkers zowel positieve als kritische feedback krijgen op de wijze waarop zij hun werkzaamheden uitvoeren. Dit coachend leiderschap kan ook een belangrijke rol spelen in het "boeien en binden" van medewerkers.

\section{Duurzame inzetbaarheid}

De vergrijzing van de medewerkers in de Metalektro zet zich verder voort. Daardoor wordt het steeds belangrijker om voldoende aandacht te hebben voor de inzetbaarheid van oudere medewerkers. Dit temeer daar de leeftijd waarop mensen met pensioen gaan steeds hoger wordt. Het is dan ook niet verwonderlijk dat een leeftijdsbewust personeelsbeleid één van de meest genoemde toekomstige speerpunten voor het HRM-beleid is.

Een goed 'Active aging' beleid kan oudere werknemers stimuleren om langer door te blijven werken. Daarbij gaat het in eerste instantie om een HRM-beleid dat zich richt op de duurzame inzetbaarheid van medewerkers in alle fasen van hun loopbaan. Daarnaast geven bedrijven aan dat zij relatief vaak een aantal HRM-tools aan oudere werknemers aanbieden: hen (gedeeltelijk) ander werk aanbieden en hen inzetten op functies waarbij de overdracht van kennis belangrijk is. Maar deze maatregelen worden slechts door een beperkt deel van de bedrijven ingezet.

De verdere ontwikkeling van duurzaam personeelsbeleid zal zich moeten richten op:

- Een proactief leeftijdsbewust personeelsbeleid voor alle werknemers.

- Investeren in de competentieontwikkeling van het oudere personeel door scholing, functieroulatie en informeel leren.

- Het faciliteren van de doorstroom van fysiek of mentaal zware functies naar andere, minder belastende functies binnen of buiten het eigen bedrijf.

- Zorgen voor een vitaliteitsbeleid dat medewerkers helpt om een gezondere leefstijl te ontwikkelen.

- Het ontwikkelen van flexibele uittredemogelijkheden gekoppeld aan deeltijdpensionering, die aansluiten bij de behoeften van het bedrijf en de medewerkers.

\section{Personeelsontwikkeling bij flexibele schil en partners in de keten}

De zogenaamde flexibele schil die bestaat uit medewerkers die tijdelijk - al dan niet via een uitzend- of detacheringsbureau - bij de productie worden ingezet, spelen een cruciale rol voor de flexibiliteit van de personeelsomvang waarmee bedrijven adequaat kunnen inspelen op de schommelingen op hun afzetmarkt. Doordat deze flexibele 
schil niet tot de kern van het personeelsbestand behoort is er veel minder aandacht voor het op peil houden van het competentieniveau van deze groep medewerkers. Zo laat figuur 4.2 zien dat medewerkers in tijdelijke dienst veel minder worden bijgeschoold dan medewerkers met een vast dienstverband, terwijl de scholingsparticipatie bij uitzendkrachten nog veel lager ligt. Vanuit bedrijfsperspectief is dit begrijpelijk omdat een bedrijf minder geneigd zal zijn om te investeren in de kennis en vaardigheden van mensen die slechts korte tijd bij het bedrijf werkzaam zijn. Gezien de continu verschuivende vaktechnische en gedragsmatige competenties waarover medewerkers in de Metalektro moeten beschikken, zal dit echter de duurzame inzetbaarheid van de medewerkers die werkzaam zijn in de flexibele schil aantasten. Dit is niet alleen voor de betrokken medewerkers zelf nadelig, maar ook voor de Metalektro als geheel. In de eerste plaats zal het bij een krappere arbeidsmarkt steeds moeilijker worden om mensen op tijdelijke basis aan te trekken voor functies die geen garantie bieden op duurzame inzetbaarheid op de arbeidsmarkt. In de tweede plaats zal de sector hierdoor steeds meer geconfronteerd worden met een flexibele schil die niet meer adequaat kan worden ingezet, omdat hun kennis en vaardigheden niet meer up-to-date zijn.

Dit betekent dat bedrijven meer aandacht kunnen besteden aan het opleidings- en ontwikkelingsbeleid met betrekking tot de medewerkers die deel uitmaken van de flexibele schil. Het ligt voor de hand dat er op dit punt op regionaal niveau kan worden samengewerkt om dit steeds belangrijker wordende aspect van het human capital beleid van de Metalektro van de grond te krijgen.

\section{Sociale innovatie}

Naast technologische innovatie, die de basis vormt voor de vernieuwing van producten en processen die cruciaal is voor de concurrentiepositie van het bedrijf, zijn ook sociale innovaties steeds bepalender geworden voor het concurrentievermogen van bedrijven. In de Metalektro is sociale innovatie vaak gericht op het variabel inzetten van technici, projectmatig werken en het samenwerken met andere bedrijven. Uit hoofdstuk $\varsigma$ blijkt echter dat het doorvoeren van dergelijke innovaties vaak de nodige tijd kost.

Sociale innovatie is ook de motor voor het realiseren van de eerder in kaart gebrachte pijlers van het human capital beleid dat metalektrobedrijven zullen moeten inzetten om de komende jaren te kunnen beschikken over de mankracht die ze nodig hebben. Dit geldt zowel voor het eigen HRM-beleid als voor de samenwerking met andere bedrijven en onderwijsinstellingen. Bedrijven zullen deze sociale innovaties moeten ontwikkelen binnen de grenzen van de mogelijkheden die het bedrijf hiervoor heeft. Dit betekent dat bedrijven zich niet moeten richten op het simpelweg kopiëren van populaire 'best practices', maar meer aandacht moeten schenken aan wat men zou kunnen aanduiden als de Research \& Development (R\&D) met betrekking tot sociale innovatie, op soortgelijke wijze als de bedrijven dat doen bij technologische innovaties. Daarbij is het verbeteren van de samenwerking met kennisinstellingen die 
bedrijven hierbij kunnen ondersteunen gewenst. Ook is het cruciaal om het personeel te betrekken bij sociale innovaties die het bedrijf wil doorvoeren. Een goede communicatie met het personeel is daarbij vanzelfsprekend van groot belang.

Voor kleinere en middelgrote bedrijven zal het doorgaans niet gemakkelijk zijn om een adequaat human capital beleid te voeren. Daar komt bij dat juist deze bedrijven de komende jaren vaak geconfronteerd zullen worden met de toenemende krapte op de arbeidsmarkt. Daarom is het van groot belang dat de kleinere en middelgrote bedrijven de effectiviteit van hun human capital beleid weten te vergroten door middel van samenwerking en kennisdeling op regionaal niveau. Dit is zeker het geval wanneer kleinere bedrijven onvoldoende informatie hebben over de mogelijkheden tot, en de voor- en nadelen van, sociale innovaties. $A+O$ Metalektro zou hierbij een belangrijke rol kunnen vervullen door de inzichten die verkregen zijn uit good practices te vertalen in een aantal toegankelijke, gemakkelijk hanteerbare en direct implementeerbare tools, zowel op het terrein van de maak-als de koopstrategie. 